Geology of the

Gardiner Area

Park County

Montana

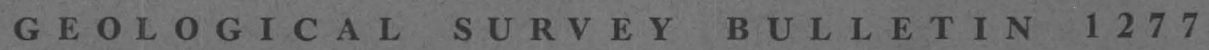

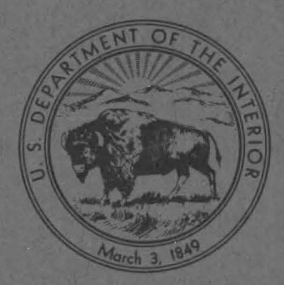




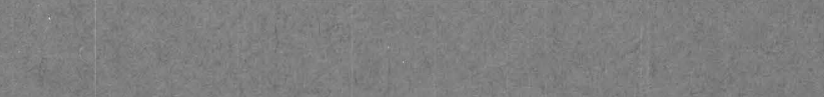

(2)

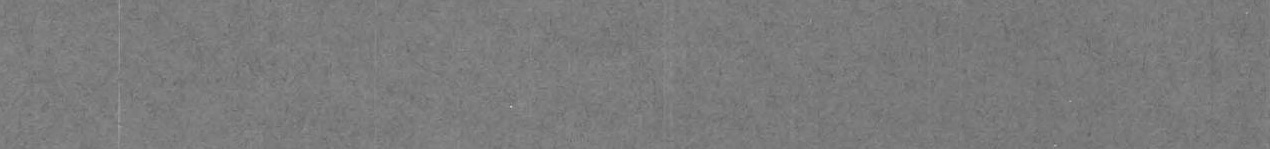

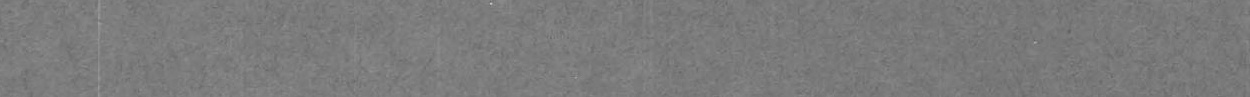

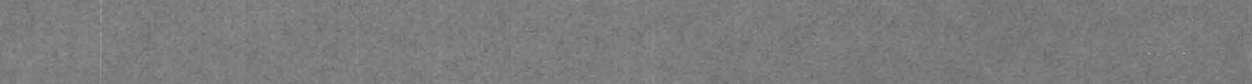

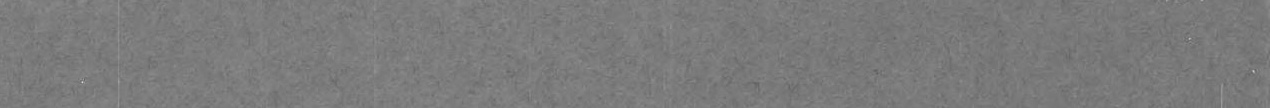

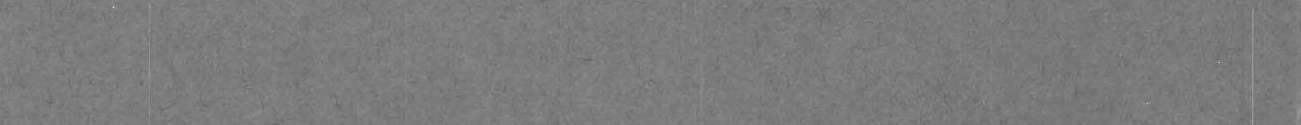
(3)

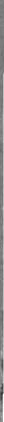




\section{Geology of the}

Gardiner Area

\section{Park County}

\section{Montana}

By GEORGE D: FRASER, HENRY A. WALDROP, and HAROLD J. HYDEN

G E O L O G I C A L S U R V E Y B U L L E T I N 1277

General geology near the North Entrance of Yellowstone National Park, with special emphasis on recurrent faulting along the boundary of the Beartooth uplift

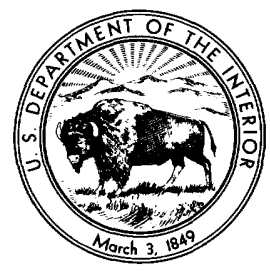


UNITED STATES DEPARTMENT OF THE INTERIOR

WALTER J. HICKEL, Secretary

\section{GEOLOGICAL SURVEY \\ William T. Pecora, Director}

Ldbrary of Congress catalog-card No. GS 68-393 


\section{CONTENTS}

\begin{tabular}{|c|c|}
\hline & Page \\
\hline Abstract.---- & 1 \\
\hline 年- & 3 \\
\hline 年 & 3 \\
\hline Fieldwork and acknowledgments & 3 \\
\hline Relation to previous geologic work & 5 \\
\hline Regional background and physiography & 6 \\
\hline recambrian geology & 7 \\
\hline Metasedimentary rocks & 7 \\
\hline Quartz-biotite schist and quartzite & 8 \\
\hline Quartz-amphibole schist and related rocks & 9 \\
\hline Phyllite $_{-}$ & 10 \\
\hline Granite & 10 \\
\hline Metagabbro_. & 11 \\
\hline Structure and geologic history & 12 \\
\hline - & 15 \\
\hline Paleozoic rocks-1 & 16 \\
\hline Madison Limestone & 16 \\
\hline Amsden Formation & 16 \\
\hline Quadrant Quartzite. & 17 \\
\hline Park City Formation & 18 \\
\hline Mesozoic rocks_. & 19 \\
\hline Dinwoody and Chugwater Formations & 19 \\
\hline Ellis Group & 20 \\
\hline Morrison Formation & 21 \\
\hline Cloverly Formation & 22 \\
\hline Thermopolis Shale...... & 23 \\
\hline Mowry Shale. & 24 \\
\hline Formation & 25 \\
\hline 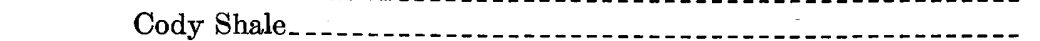 & 26 \\
\hline Telegraph Creek Formation & 27 \\
\hline Eagle Sandstone & 28 \\
\hline Everts Formation & 32 \\
\hline Landslide Creek Formation. & 34 \\
\hline ks & 37 \\
\hline Lower Cenozoic volcanic rocks. & 37 \\
\hline Dacitic breccia & 37 \\
\hline Trachyandesite flows & 41 \\
\hline Andesitic breccia & 44 \\
\hline Intrusive rocks.-. & 47 \\
\hline Dacitic intrusives north of the Gardiner fault & 47 \\
\hline Intrusives in or near the Gardiner fault & 47 \\
\hline Dacite sill south of the Gardiner fault & 48 \\
\hline Andesite sill at Mount Everts. & 49 \\
\hline Upper Cenozoic volcanic rocks & 49 \\
\hline Basalt & 49 \\
\hline Yellowstone Tuff_. & 53 \\
\hline
\end{tabular}


Stratigraphy-Continued

Cenozoic rocks-Continued

Surficial deposits............

Conglomerate beneath basalt_.........

Conglomerate younger than basalt..........

Travertine.-.-...-.

Glacial deposits..................

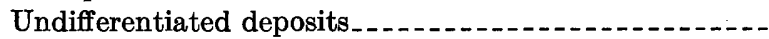

Pinedale deposits. .

Landslides

Alluvium and colluvium

Structure

Regional relations_...

Gardiner fault_.

Dip.

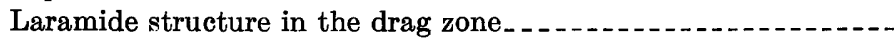

Surficial modification of drag-zone structure

Quaternary reactivation of Gardiner fault

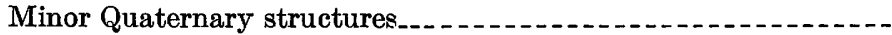

Age of the young faults............

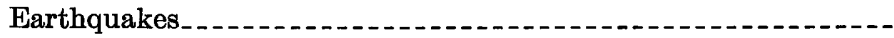

Transverse faults.

Mammoth fault

Age.-.

Other faults and folds

Economic geology

Coal deposits...

Electric coal field._...

Little Trail Creek area..

Gardiner area..

Economic potential

Other deposits.

Gold, arsenic, and tungsten.........

Oil and gas prospects.

Nonmetallic deposits_...

Geologic history

Measured sections.

\section{ILLUSTRATIONS}

Plate 1. Geologic maps and section of the southwest quarter of the Gardiner quadrangle.

Figure 1. Index maps of Gardiner area

2. Photograph of irregular channel-filling basalt flow

3. Diagram illustrating faults in downthrown drag and shear zone adjacent to a high-angle fault. 
FIGU RE 4. Photograph of Gardiner fault and drag zone showing Quaternary uplift of Pliocene(?) basalt, Holocene superficial faults, contact between sedimentary rock and Precambrian granite, and Landslide Creek Formation...............-

5. Photograph of Quaternary graben in Pliocene(?) basalt and distant view of Cinnabar Mountain

6. Diagrammatic cross sections showing Quaternary disruption of

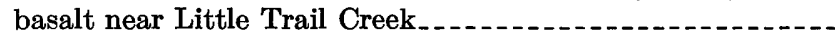

7. Photograph of Holocene tilted fault blocks in Pliocene(?)

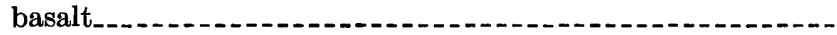

\section{TABLES}

TABLE 1. Pelecypods from Eagle Sandstone near Gardiner, Mont.....

2. Measured sections and total thicknesses.................... 



\section{GEOLOGY OF THE GARDINER AREA, PARK COUNTY, MONTANA}

By George D. Fraser, Henry A. Waldrop, and Harold J. Hyden

\section{ABSTRACT}

The Gardiner area occupies about 52 square miles in the southwest quarter of the Gardiner 15-minute quadrangle in southwestern Park County, Mont., at the North Entrance to Yellowstone National Park. The Gardiner area is divided into two blocks by the high-angle northwest-trending Gardiner reverse fault. Northeast of the fault the uplifted Beartooth Mountains block is crystalline Precambrian rock stripped of its sedimentary cover and veneered by Eocene and younger volcanic rocks and surficial deposits. Southwest of the fault the dropped and deformed Yellowstone valley block has 10,000 feet of Paleozoic and Mesozoic rocks and is also veneered by Cenozoic volcanic rocks and surficial deposits. The sedimentary rocks, mostly Cretaceous at the surface, dip generally toward the fault but are truncated, curled upward by drag, sheared, and thinned to form a 1-mile-wide deformed zone that is the steep limb of a locally overturned syncline parallel to the Gardiner fault. Oretaceous rocks are generally in contact with Precambrian rocks along the fault, although lower Paleozoic rocks were deposited throughout the area and sedimentary remnants as old as Mississippian are exposed locally in the drag zone. A large graben, transverse to the trend of the Gardiner fault, is confined to the dropped block and helps to localize spurs of Sepulcher Mountain and Mount Everts that project northward into the valley from Yellowstone National Park.

Poorly exposed lower Precambrian rocks, which include deformed metasedimentary rock, gneissic granite, and weakly metamorphosed gabbro, indicate a complex history as follows: (1) Prolonged deposition, (2) downbuckling, intense folding, regional amphibolite-facies metamorphism, and cross-folding, (3) localized thermal metamorphism, granite intrusion, and mild deformation, (4) gabbro intrusion, (5) localized quartz-pegmatite intrusion, hydrothermal metamorphism, gold-arsenopyrite-scheelite mineralization, retrograde greenschist-facies metamorphism, and mild deformation accompanied and followed by (6) prolonged uplift and erosion. The uplift, which may have begun during step 3, probably continued spasmodically throughout much of late Precambrian time, so that no Belt rocks had been deposited and plutonic rocks were at sea level by the time Middle Cambrian sedimentation began.

From Cambrian through Triassic time, the area was well out on the stable shelf of the Cordilleran geosyncline, and only about 2,100 feet of pre-Jurassic rock remains. About 8,000 feet of sedimentary rock was deposited here, mostly in Late Oretaceous time, in the short-lived Rocky Mountain geosyncline, whose north-south axis passed through the Yellowstone region. However, in Phanerozodc time this region was never the scene of very thick geosynclinal sedimentation or deep burial, and from Niobrara time onward continental deposition dominated. 
Here the coal-bearing Eagle Sandstone (partly marine) is of Niobrara age and nearly all younger rocks are continental. Above the Eagle two new Upper Cretaceous units, the Everts and Landslide Creek Formations, which are separated from each other by an erosional unconformity, are roughly equivalent to parts of the Livingston Group 40 miles to the north, but they have not been precisely dated. The largely fluvial Everts is lithologically similar to the Eagle but much less carbonaceous. The Landslide Creek Formation, last of the sedimentary rocks, contains abundant andesitic debris and becomes more volcanic and conglomeratic to the west or northwest. Gentle differential uplift and compartmentation of the geosyncline probably began during or shortly after Niobrara time, but extensive faulting and orogeny did not begin in this immediate area until later, after deposition of the Landslide Creek Formation, probably in late Pierre time.

Because of the Laramide orogeny, about 20 million years of geologic time is missing from the stratigraphic record. The major mountain blocks formed and were deeply eroded in Laramide time, and little differential movement has occurred since. The Gardiner fault is a high-angle reverse fault that dips northeast. Other major faults are also high angle. There is little evidence for strong lateral compression, though in some nearby areas the structural style is quite different. A topographic relief of nearly 5,000 feet-similar to that of todayexisted in late early Eocene time when recorded Cenozoic volcanism began. Exhumed Eocene valleys form part of the present drainage pattern.

Cenozoic volcanic rocks of the Yellowstone region, which occur here only as scattered erosion remnants, are divisible into two strongly contrasting parts. In the Gardiner area the lower part (Eocene) is divisible into dacitic (early acid) breccia, trachyandesite flows (local, partly new unit of mildly potassic rock), and andesitic (early basic) breccia. The three Eocene map units belong to the earlier of two felsic-to-mafic breccia cycles long recognized in the Yellowstone region. The much younger upper part is represented by remnants of five Pliocene(?) basalt flows that moved down the Yellowstone valley from somewhere in the park, and by remnants of a Pleistocene rhyolitic ash-flow sheet that moved northward from the park.

Huge trunk glaciers about 90 miles long passed through Gardiner, where they were about 5 miles wide and 2,500 feet thick. Melt-water and subsequent stream erosion incised the basalt and older rocks as much as 800 feet in places.

In Pleistocene time, a short segment of the Gardiner fault at the northwest end of the Beartooth uplift was reactivated structurally but not volcanically. Quaternary reactivation of the fault $(400 \mathrm{ft})$ is indicated at the west edge but not the east edge of the mapped area. Hot springs, localized by the fault, depasited large amounts of travertine in Pleistocene and Holocene time.

Large landslides, mostly of Holocene age, whose movement probably has been aided by earthquakes, continue to move into the Yellowstone and Gardner River valleys from Sepulcher Mountain. Earthquakes, some probably localized along the Gardiner fault, have been partly responsible for hundreds of Holocene superficial fissures and normal faults in unstable parts of the basalt-covered bench northwest of Gardiner. Under the basalt and elsewhere, superficial creep of the drag zone of the Gardiner fault accounts for much of its locally extreme overturning to dips as low as $35^{\circ}$, but Laramide orogenic drag to and slightly beyond the vertical is general throughout the same zone. The two effects can be separated clearly only where broken and tilted basalt remains above weak Oretaceous beds.

Coal lenses in the Eagle Sandstone are accessible in Yellowstone National Park where they cannot be mined. They also occur in isolated pockets within the drag 
zone where small size, steep dip, extreme deformation, and heavy cover make the deposits noncommercial.

Measured sections of mast sedimentary formations younger than the Madison Limestone and mostly from nearby areas (Cinnabar Mountain, Mount Everts) are given to supply stratigraphic information that cannot be gained in the sheared poorly exposed rocks of the mapped area.

\section{INTRODUCTION}

This report describes the geology of a 52-square-mile area that includes parts of the Beartooth uplift, the Yellowstone River valley, and Yellowstone National Park. In addition, measured sections from Cinnabar Mountain and other adjacent areas are included because the structurally modified stratigraphy of the mapped area cannot be understood without them. Fieldwork was done during the summers of 1960 and 1961 as part of a study by the U.S. Geological Survey to classify coal-bearing lands and to extend the geologic map of the United States on a modern large-scale topographic base. Coal deposits of the mapped area are in the Cretaceous Eagle Sandstone which crops out locally, but have never been mined successfully. Quaternary placer deposits of gold and Precambrian vein deposits of gold, arsenic, and tungsten have been mined in the past but are not being worked now and are not described in detail in this report.

\section{LOCATION}

As defined for this study the Gardiner area (fig.1; pl. 1) is the southwest quarter of the Gardiner, Mont., 15-minute quadrangle, whose southwest corner is at lat $45^{\circ} 00^{\prime} \mathrm{N}$., long $110^{\circ} 45^{\prime} \mathrm{W}$. The area is in Park County, southwestern Montana, and is mostly in Gallatin National Forest but includes along its south margin a strip 2-3 miles wide of Yellowstone National Park. The Wyoming State line is about half a mile south of the quadrangle boundary.

The tourist, hunting, fishing, and ranching center of Gardiner lies at the junction of the Yellowstone and Gardner Rivers at the North Entrance of Yellowstone National Park. The city of Gardiner is connected with park headquarters, 6 miles south at Mammoth, Wyo., and with Livingston, Mont., 56 miles north, by U.S. Highway 89 and is also served by a spur of the Northern Pacific Railroad, a bus line, and a small airstrip. Jardine, an old gold camp, is 5 miles northeast of Gardiner and can be reached by gravel road.

\section{FIELDWORK AND ACKNOWLEDGMENTS}

Fieldwork for this report was done by George D. Fraser and Harold J. Hyden from July to October 1960 and during June 1961 and by George D. Fraser and Henry A. Waldrop from July to September 1961. Fraser wrote the report and is largely responsible for bedrock areas of the map. Hyden and Waldrop assisted in all phases 

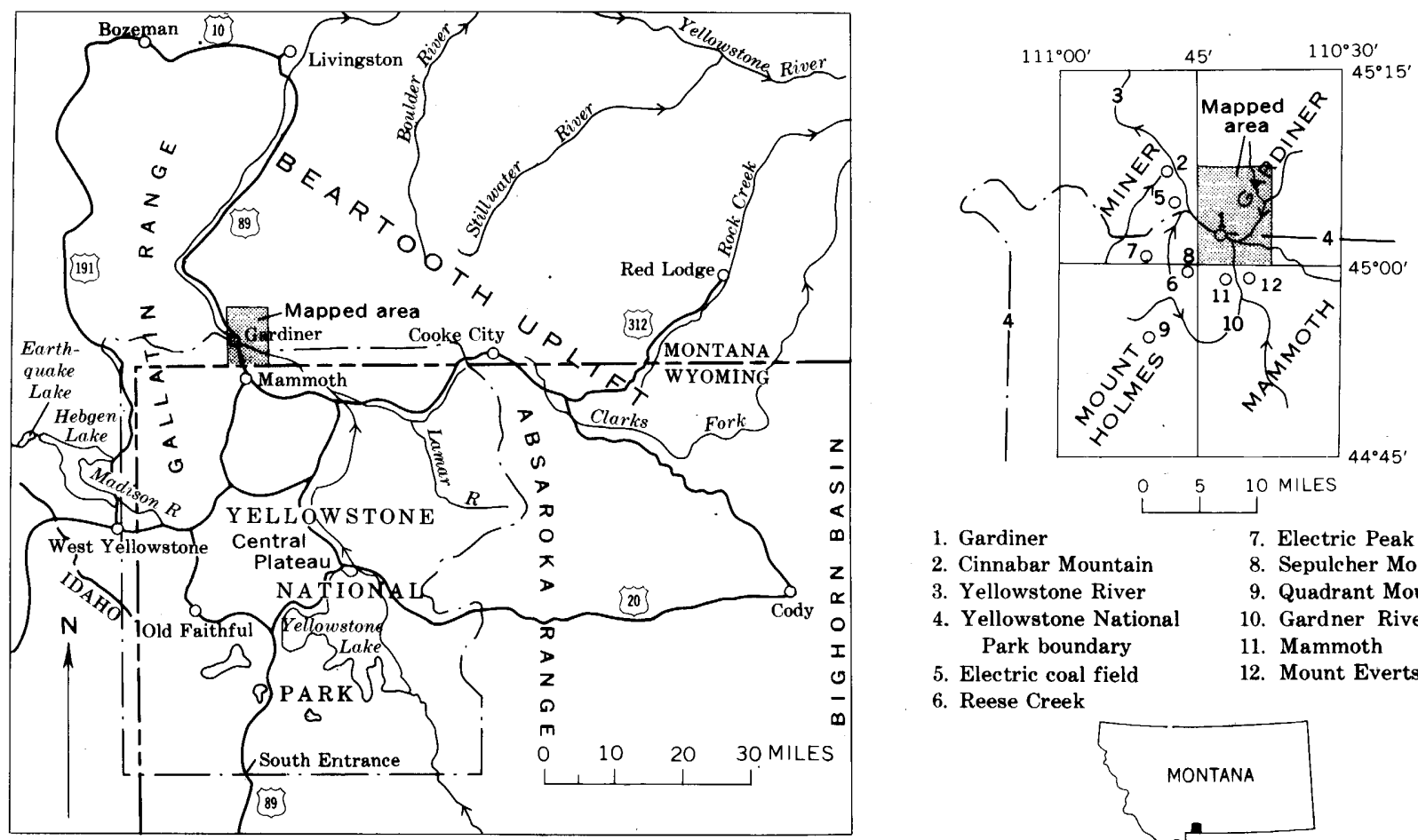

1. Gardiner

2. Cinnabar Mountain

7. Electric Peak

8. Sepulcher Mountain

3. Yellowstone River

4. Yellowstone National

9. Quadrant Mountain

Park boundary

10. Gardner River

5. Electric coal field

11. Mammoth

6. Reese Creek

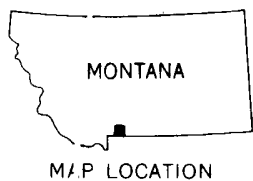

FIgURE 1. -Index maps of Gardiner area, showing location of Yellowstone National Park, Beartooth uplift, and selected features in adjacent quadrangles. 
of the work and are largely responsible for mapping surficial deposits.

Mapping was done mostly on 1:24,000 enlargements of the 1:62,500 Gardiner topographic map using conventional compass, pace, and inspection methods of location. A small faulted area in the southeast corner (pl. 1) was planetabled, and areas dominated by surficial deposits or characterized by poorly defined topography generally were mapped on aerial photographs first, and the mapping was then transferred to the topographic base. Stratigraphic sections were measured by Jacob's staff, tape, and hand level.

We are indebted to many Survey colleagues who were consulted in field and office phases of the work, to Professors Willard A. Parsons and Richard F. Ward of Wayne State University and John de la Montagne of Montana State University, to John M. Good of the National Park Service, and to Otho Mack, a Gardiner resident. All these people supplied useful geologic information on the area. Personnel of the National Park Service and the U.S. Forest Service were helpful in providing access and geographic information for some areas.

\section{RELATION TO PREVIOUS GEOLOGIC WORK}

Although there were earlier studies, the classic reconnaissance of the Yellowstone region published in several papers near the turn of the century (Iddings and Weed, 1894; Hague and others, 1896, 1899 ; Hague, 1904) is the foundation for all later work. Later papers illuminate special aspects of the geology: coal geology (Calvert, 1912), stratigraphy and Laramide structure (Wilson, 1934a, b), Precambrian geology and ore deposits (Seager, 1944), and regional structure (Foose and others, 1961). More specialized papers are cited in pertinent sections.

In the choice of rock units for mapping or description and in most other particulars, this report follows generally the guidelines of Seager (1944) for the Precambrian, Wilson (1934a, b) for the Paleozoic and Mesozoic, and J. P. Iddings (in Hague and others, 1899) for the Cenozoic volcanic rocks. Some formation names and ages are changed, eliminated, or added as required by map scale or current opinion and practice. Two new formation names, the Everts Formation and the Landslide Creek Formation, both of Late Cretaceous age, are introduced. Quaternary map units are altered more drastically from preceding studies, mainly to show some new detail and to identify landslide deposits that previously had been mapped as glacial till or bedrock.

We depart from Wilson (1934a) in some conclusions that pertain to the Gardiner fault. In particular, we advocate a high dip for the 
fault plane. Our interpretation of the attitude of the fault is more nearly in accord with the original one of Iddings and Weed (1894) and of others (Calvert, 1912; Brown, 1961; Foose and others, 1961). Reexamination of the drag zone, including the Pliocene(?) basalt that was deposited there from a source outside the mapped area, has yielded new information on the post-Laramide history of the Gardiner fault. Apparently the fault was locally reactivated (uplift about $400 \mathrm{ft}$.) in Pleistocene time, and then the drag zone was superficially remobilized by earthquake shaking, downhill movement, and collapse in Holocene time. When this late deformation, much of which is creep, is subtracted from the total amount of deformation, the overturned beds in the drag zone have a vertical attitude, and a high dip on the Gardiner fault seems certain.

\section{REGIONAL BACKGROUND AND PHYSIOGRAPHY}

The Gardiner area lies on the line between the Middle and Northern Rocky Mountains physiographic provinces of Fenneman and Johnson (1946) and mostly within the northwest-trending Beartooth uplift (Foose and others, 1961; Cohee and others, 1961). This same mountain mass is shown as part of a diffuse Absaroka Range on some maps, and its western part is shown as the Snowy Mountains on other maps. In this report the Absaroka Range is restricted to the dominantly volcanic range extending southward from the Beartooth aplift along the east edge of Yellowstone National Park (fig. 1), and the name "Snowy Mountains" is not used. The Beartooth uplift is outlined mostly by streams on its south and west margins and less definitely by topography on the north and the east. In addition, nearly the entire uplift is structurally outlined by faults, among which is the Gardiner fault in the mapped area.

The eastern edge of the Gallatin Range is defined at this latitude by a set of northeast-trending faults and stream valleys. The range lies 1-3 miles west of the mapped area and extends southward into the park and northward toward Bozeman, Mont., to form an $\mathrm{L}$ with the Beartooth uplift. As shown on the geologic map by Iddings and Weed (1894), the Yellowstone River and its tributaries from the Gallatin Range etched out the nearly perpendicular structural junction between the ranges 6-15 miles northwest of Gardiner; downstream from that area the Yellowstone flows northeast, parallel to the fault-bounded terminus of the Beartooth uplift. Evidence within the Gardiner area and north of it indicates clearly that the northwest end of the Beartooth uplift is presently active. (See section on "Structure"; also, Horberg, 1940.) But other evidence suggests that 
the principal movement on most large faults occurred in Laramide time.

Topographic relief within the Gardiner area in the uplifted or Beartooth block exceeds 5,200 feet, and a local relief of more than 2,500 feet is common. Much of this topography has been exhumed from beneath Eocene volcanic cover. The highest peak, Sheep Mountain, is 10,547 feet above sea level. In the dropped block, total relief is only 2,900 feet, and the highest point is 8,100 feat above sea level. Here also Eocene topography has been exhumed. Ancient and modern channels of the Yellowstone River, whose location on the dropped block is largely controlled by the Gardiner fault, have carved a broad valley - the only significant nonmountainous part of the area. Spurs of Mount Everts and Sepulcher Mountain (fig. 1) project northward into the valley at the south edge of the mapped area from a structural, topographic, and volcanic highland in Yellowstone National Park. The spurs are separated from each other by a transverse northeast-trending fault (east margin of the Sepulcher graben, pl. 1) which helped to localize the Gardner River.

\section{PRECAMBRIAN GEOLOGY}

Outcrops of Precambrian rock in the Gardiner area are too far apart to allow resolution of the lithologic and structural patterns. Consequently, the Precambrian is treated in a general way in this report, and most inferences are based on scattered field observations. Seager's detailed study (1944) of a part of the area and of an adjacent area to the east was of great value in the preparation of this report.

The Precambrian rocks consist of (1) a schistose sequence of highly deformed metasedimentary rock intruded by (2) gneissic granite with (generally) unfolded apophyses and by (3) weakly metamorphosed and unfolded gabbroic dikes, sills, and pods.

\section{METASEDIMENTARY ROCKS}

The oldest Precambrian rock unit can be divided into many contrasting layers, but no attempt was made to map them. In order of decreasing areal abundance, the principal divisions are (1) quartzbiotite schist, commonly containing small amounts of minerals indicative of grade or kind of metamorphism; (2) quartzite, generally biotitic; (3) quartz-amphibole schist and related rocks; and (4) phyllite. 


\section{QUARTZ-BIOTITE SCHIST AND QUARTZITE}

All gradations between quartzite and schist occur, but in most places the schist is dominant. The quartzite and some quartz-rich schist are refractory, devoid of garnet, and not useful in estimates of metamorphic grade. The more pelitic layers commonly contain quartz, biotite, muscovite, almandine, and oligoclase-andesine. Staurolite also occurs sporadically in a southeast-trending zone about $41 / 2$ miles long from Niggerhead Peak to a point 1 mile south of Jardine. Small amounts of sillimanite were found near Niggerhead Peak, and probably the mineral occurs elsewhere within a relatively high grade metamorphic zone whose shape, continuity, and width are unknown. In most of the mapped area the metamorphic rocks were raised to at least garnet grade, though a few small patches of low-grade phyllite were noted. Metamorphic intensity probably diminishes toward the northeast, away from the granite. Mineral associations found generally throughout the region indicate the almandine amphibolite facies of Fyfe, Turner, and Verhoogen (1958, p. 228). Chlorite found locally within the high-grade schist is attributed to retrograde hydrothermal metamorphism.

Within the staurolite zone, andalusite is more common than staurolite, and plagioclase is abundant. Moreover, andalusite is common in schist south of Deckard Flats where no staurolite was found. Partly resorbed garnet remains in some andalusite rocks. The andalusite is associated with bleached biotite and, locally, where staurolite is present, replaces it. Staurolite is commonly bent or granulated, but andalusite is not. These relations suggest that the andalusite metamorphism (hornblende hornfels facies of Fyfe and others, 1958, p. 208) occurred after intense deformation and regional metamorphism. The largest andalusite crystals, $21 / 2$ inches long, occur near the middle of sec. 12, T. 9 S., R. 8 E., more than 2 miles from exposed granite. In the Little Trail Creek area, most of the schist in contact with granite does not contain andalusite. Nevertheless, the thermal metamorphism is related in space and probably in time to granite intrusion, for most of the andalusite occurs within $21 / 2$ miles of exposed granite, and all of it probably occurs above concealed granite.

In some places the schist within 2 feet of granite contacts is coarsely recrystallized and locally spotted with cordierite. In several places schist in contact with granite is not changed appreciably and is not feldspathized or injected with granitic material.

In addition to much primary or sedimentary quartz, quartz veins and lenses of different ages and origins are common in the highly metamorphosed areas. Small quartz-rich pegmatites and aplites are much less common. Those veins that were involved in the extreme 
deformation probably were an essential part of the regional metamorphic process, perhaps as agents in the transfer of wallrock and foreign material and certainly as agents for upward heat transfer. Black tourmaline is conspicuous in a few quartz veins, and garnet is concentrated in or near many quartz veins. In a few areas andalusite and sillimanite are present only in pegmatite or aplite dikes (Seager, 1944, p. 30,62). However, not all the minerals generally attributed to regional metamorphism are localized in this way. Most regional metamorphism is more diffuse, and at least some high-grade hydrothermal metamorphism is demonstrably late, as it is associated with undeformed veins or dikes and was apparently part of the episode of ore deposition. Indeed, many solutions were late and cool enough to induce retrograde changes from biotite to chlorite in schist or very low grade changes in young gabbro. A specific age or a specific origin can not be assigned to much of the vein quartz. Most of it probably was linked, at least thermally, to the granite plutons; but some quartz arrived before, some with, and some long after the granite.

\section{QUARTZ-AMPHIBOLE SCHIST AND RELATED ROCKS}

Metasedimentary layers rich in quartz and amphibole range in thickness from a fraction of an inch to about 50 feet and are intercalated with the quartz-biotite schist and quartzite. The amphibole rocks range widely in composition and structure, depending mostly on the amount and arrangement of original quartz. Most of the rocks are not true amphibolites because of the high quartz and low plagioclase content. Except near veins in the Jardine area, where retrograde chlorite and biotite are abundant, fissility is poor or lacking; but bedding and an imperfect foliation that results from a subparallel arrangement of amphibole grains are present in most rocks.

Quartz-cummingtonite rocks are abundant and economically important in the Jardine district, where they were a favorable host for arsenopyrite-gold mineralization. Seager (1944, p. 24-27) described three distinct varieties of cummingtonite rock and noted that many, and perhaps most, garnets are hydrothermal. Seager also noted that much cummingtonite is recrystallized hydrothermally, some hornblende is a hydrothermal modification of cummingtonite, and most of the chlorite and biotite is also hydrothermal though indicative of cooler solutions. Some biotite may be primary. The layered cummingtonite rocks show that this area was metamorphosed to the amphibolite facies before mineralization.

Metasedimentary quartz-amphibole rocks occur sporadically throughout the Precambrian area northwest of Jardine, though they are less abundant than in the Jardine district, and the quartz and 
garnet content diminishes toward the northwest. One outcrop of a conspicuously banded rock that is very rich in magnetite but without visible garnet was found $31 / 2$ miles west of Jardine. Amphibolite and amphibole gneiss, possibly belonging to the same ancient sequence but of questionable sedimentary origin, also occur in this area.

\section{PHYLIITE}

On the ridge northeast of Five Lakes, near the east entrance to the Five Lakes cirque, and in a few other areas, small patches of garnetand feldspar-free phyllite were noted. These rocks are composed primarily of quartz, biotite, and muscovite that are much finer grained than the surrounding schist. The phyllites were not mapped because exposures are poor, and their relations with the associated schists are unknown. The low-grade rocks may be downfaulted or thrust into the high-grade area, they may be enclaves of low-grade rock bypassed by metamorphosing solutions, or they may represent a younger sequence of rocks deposited unconformably on the highgrade rocks.

\section{GRANITE}

The metasedimentary rocks were intruded by plutons of gneissic granite in two areas-one in the extreme western part of the mapped area and the other in the southeast corner. The plutons are probably connected at depth, for a metamorphic zone rich in andalusite almost bridges the gap between the two areas. Exposed parts of the granite are small and irregular; so no definite conclusions regarding the regional orientation or alinement of plutons are possible.

The granite is mineralogically homogeneous over wide areas but differs in color and texture from area to area. A variety common north of the Yellowstone River on the east edge of the mapped area is medium grained, medium light gray, and vaguely gneissic. Its estimated mineral composition, in percent, is microcline and microcline perthite, 40-50; quartz, 20-30; oligoclase, 15-25; biotite, 5-10; and muscovite, $2-7$. Some oligoclase is altered to sericite, and myrmekite is common.

The structure of the granite differs from that in most gneisses in that the minerals, though crudely alined, are not segregated into layers. The rock has a granulated structure which Seager (1944, p. 29) believed to be cataclastic and metamorphic in origin. We believe the structure to be protoclastic-the result of intergranular shear during forcible injection of a pasty mass.

Homogeneity of the granite, sparse and sharply defined inclusions, absence of relict sedimentary or metamorphic structures, sharp and locally discordant contacts, and thermally metamorphosed contacts 
and roof zones all indicate magmatic granite. Though local migmatitic borders and local inclusion-rich areas indicate some marginal granitization or metasomatism, the bulk of the granite probably was formed and homogenized well below the level of exposure and then intruded as a relatively dry crystal mush hotter than the country rock.

\section{METAGABBRO}

Dark-gray to black gabbroic sills, dikes, and small plutons intruded the schist after the principal deformation and metamorphism. These rocks are more resistant than the schist, and some form conspicuous outcrops. The term "metagabbro" is used in this report to designate all such rocks, though metamorphism is weak and incomplete and texture is variable. In general, the larger masses are medium or coarse grained and locally porphyritic, and the smaller dikes and sills are porphyritic or diabasic. A few bodies, both large and small, have fine-grained chill margins. Microscopic textures are mostly ophitic or diabasic. A primary gneissic structure is present locally and is especially conspicuous near Sheep Mountain in a group of coarse-grained and locally porphyritic sills.

Original essential minerals were plagioclase and augite, but most augite was later converted to actinolite and at least some plagioclase was also changed. Primary plagioclase ranges from calcic andesine to bytownite and, in most of the rocks examined, is not obviously zoned. In one common and conspicuous rock, plagioclase crystals occur as phenocrysts that average about 1 inch in diameter but are as large as $21 / 2$ inches. In many sills the phenocrysts are preferentially arranged and imperfectly alined near one or both margins, probably as a result of primary flow. In most rocks the coarse crystals are undeformed, but in some they are fractured.

In the least altered rocks, only about one-third of the augite has been converted to amphibole, and the plagioclase is nearly fresh. In most rocks, however, all augite has been changed to amphibole, and much groundmass plagioclase has been changed to a complex mixture containing clinozoisite, quartz, chlorite, calcite, albite, and actinolite. Generally the large feldspar phenocrysts resist alteration. Biotite, probably of secondary origin, is a common minor constituent. Quartz was introduced during the low-grade changes, and alteration is visibly more intense along some veins.

The gabbroic rocks, though now composed largely of plagioclase and amphibole, were not metamorphosed to the amphibolite facies as redefined by Fyfe, Turner, and Verhoogen (1958, p. 228). The actinolitic amphibole, clinozoisite, and albite are lower greenschist-facies 
minerals, and only part of the primary plagioclase has been altered. Such low-grade changes, had they occurred before the high-grade ones, would have been upgraded. The apparent restriction of lowgrade change to the gabbro suggests deuteric alteration. Possibly, however, a weak and selective metamorphism was induced during one or more late episodes of quartz deposition and is conspicuous only in the previously unmetamorphosed gabbro. Along mineral veins in the Jardine district, retrograde changes are conspicuous in the older metamorphic rocks, and the gabbro is extensively altered (Seager, 1944, p. 62).

Fold-axis lineation common in the schistose rocks was not found in gabbroic dikes and sills. The shearing in the gabbro, some of which is extreme (Seager, 1944, p. 32), probably resulted from subsequent faulting, for it was not accompanied by high-grade metamorphism. Structural and petrographic evidence, therefore, shows that the gabbroic rocks are younger than the principal deformation and regionaI metamorphism.

Seager (1944, p. 33) believed most gabbro to be pregranite because in a few places pegmatite cuts gabbro and in many places quartz veins genetically associated with granite cut gabbro. The gneissic granite was never found cutting gabbro, but at Rattlesnake Butte a gabbro dike cuts granite. At least some gabbro, therefore, is younger than some granite. The gabbro, however young, is Precambrian in age because it does not penetrate Paleozoic or Mesozoic rocks and is cut by pegmatites and mineral veins of a type not found in adjacent Paleozoic and Mesozoic rocks.

The definite genetic and time distinction between young metagabbro and old metasedimentary amphibole rock is apparent in many but not all areas. The metagabbro as mapped includes amphibole rocks of questionable origin and age and probably some metasedimentary amphibolite or amphibole gneiss. In addition to this imprecision, the incomplete exposures require that most metagabbro be mapped with outcrop rather than intrusive boundaries. The impression gained in the field is that sills are more common than dikes.

\section{STRUCTURE AND GEOLOGIC HISTORY}

A tentative sequence of Precambrian events is as follows: (1) Prolonged deposition and deep burial; (2) downbuckling, intense folding (north to northeast axes), regional metamorphism and quartzvein emplacement, and cross-folding (diverse axes); (3) localized thermal metamorphism, granite intrusion, and mild deformation; (4) gabbro intrusion; (5) localized quartz-pegmatite intrusion, hydrothermal metamorphism, gold-arsenopyrite-scheelite mineralization, 
retrograde metamorphism, and mild deformation accompanied and followed by (6) prolonged uplift and erosion.

A long series of preliminary events that culminated in the uplift and erosion of a nearby felsic landmass can be inferred from the metasedimentary rocks in the Gardiner area. The thick pile of siliceous or sandy shale, impure sandstone, and siliceous iron-magnesium(carbonate?) rock could not have been derived from a simple volcanic mountain chain. As old and complex as the Gardiner rocks are, they probably were derived from still older and similarly complex rocks. During and after deposition in the Gardiner area, the rocks were buried and downbuckled.

A regional north- to northeast-striking schistosity, generally parallel to bedding and commonly dipping $20^{\circ}-60^{\circ}$ in either direction perpendicular to the strike, is apparent in most areas (pl. 1; Seager, 1944, p. 38). Between competent layers the schist has been disharmonically crenulated in places, and nearly everywhere it has been cross-folded and lineated in directions that seem incompatible with a north- to northeast-striking fold system. Though a doubly plunging northeast-striking anticline is suggested by the schistosity pattern near the west edge of the mapped area, such folds cannot be positively identified unless some beds are individually mapped. Seager $(1944$, p. 38) was similarly cautious in identifying a possible southplunging syncline in the Jardine area. Unless there were three periods of folding, the first producing undetected recumbent and isoclinal folds, the regional schistosity probably is not an axial-plane structure, for axial regions in which bedding and schistosity intersect have not been found, and schistosity parallel to bedding dips in opposite directions on the limbs of probable folds. Large Precambrian folds that plunge in a southerly direction have been mapped $50-75$ miles east of Gardiner in another part of the Beartooth uplift (Foose and others, 1961, pl. 1).

Small cross-folds a few inches to more than 100 yards across are imprinted on the regional schistosity. Most of these are open, and the schistosity parallels the bedding. Fracture cleavage related to the cross-folds is present locally but was not mapped. Plotted lineations are mostly fold axes and rodding of this generation, but a few are intersections (of fractures and schistosity) parallel to cross-fold axes. In nearly all localities the lineation plunges downdip in the regional schistosity and strikes at a high angle to the presumed early folds. Locally the plotted lineation may coincide with fold axes of the first generation. In areas of a few square miles the lineations commonly are consistent, but orientation changes abruptly from one area to another. Such erratic cross-folds or lineations commonly are attribu- 
ted to superposed folding, but other explanations which invoke a single sustained deformation or folds in $a$ as well as $b$ cannot be dismissed in the Gardiner area without more detailed study.

There is evidence suggesting a significant compression perpendicular to the axes of some cross-folds. Several of the larger second-generation folds are visible from the Five Lakes cirque. These are overturned to the south or southwest, and at least one is broken by a thrust fault. Even though the visible structures are not major ones, they indicate compression in a direction incompatible with the regional schistosity. If the granite was forcibly injected, as seems to be required by internal structure and deformation of some apophyses, some cross-folds could have formed during injection.

Most of the deformation, however, and the metamorphic changes that generated gneissose rocks locally and garnet-grade schists generally, happened before the granite was intruded. After relaxation of the intense compression and perhaps after some uplift, part of the region was again heated and andalusite formed in the schists. Probably neither the high-grade schist nor the andalusite could have formed without extra heat supplied by the rising granite and distributed by solutions derived partly from the granite and partly from the wallrock itself.

The granite, then, was relatively cool and, in most areas, dehydrated before intrusion at the level now exposed; but it was hot enough that very local cordierite zones formed along its margins and small areas of migmatite formed locally. After the granite was emplaced, and possibly as a result of that intrusion, the region became rigid, and this ended further extreme folding.

Most gabbro is younger than the high-grade metamorphism and the lineation-producing cross-folds, and at least some gabbro is also younger than the granite. By the time the gabbro was intruded, the schistose wallrock was cool enough to fracture as a brittle material and to chill the gabbro that filled fractures and foliation planes. Subsequent metamorphism was not intense enough to convert gabbro to high-grade amphibolite.

High-temperature arsenopyrite-gold-scheelite mineralization at Jardine was instrumental in the formation of new garnet and the recrystallization of high-grade metamorphic minerals, but it seems to have been a late hydrothermal result of granite intrusion (Seager, 1944, p. 74). Most of this hydrothermal activity took place after the gabbro was intruded. Low-grade metamorphism of the gabbro and retrograde metamorphism along mineral veins at Jardine probably was caused by slightly younger and cooler solutions also derived, at least in part, from deep granite. 
The uplift that may have begun during the andalusite stage of metamorphism continued for a long time. If the depth-zone concept of metamorphism is valid, the weakly metamorphosed gabbro must have been emplaced after considerable uplift. By the time Cambrian sediments were deposited, metasedimentary rocks that had been depressed many miles were once again at sea level. Most of the uplift and erosion must have taken place after the granite was emplaced. Rocks above those now exposed probably were a source for sediments deposited elsewhere during Belt time, for Belt rocks have not been found in the Beartooth region.

\section{STRATIGRAPHY}

Part of the Madison Limestone and all pre-Madison Paleozoic formations in the area have been cut out by the Gardiner fault (pl. 1). Near Cinnabar Mountain (fig. 1), which is 6 miles northwest of Gardiner and 2 miles west of the mapped area, these formations are exposed or their presence is indicated by float. Wilson (1934b) recorded the following: Flathead Sandstone, Cambrian, indicated by float (other Cambrian formations may be present as well); Bighorn Dolomite, Ordovician, 126+ feet; Jefferson Limestone, Devonian, 116 feet; and Three Forks Shale, Devonian, 122 feet. McMannis $(1962$, pls. 4, 5) indicated different thicknesses for Ordovician and Devonian rocks here.

Formations from the Madison Limestone to the Frontier Formation are exposed only locally and in part in the drag zone of the Gardiner fault (pl. 1). They cannot be studied in detail because all or parts of them commonly are sheared out, covered, or intensely deformed. Consequently, reference is made to the Cinnabar Mountain section, where the formations, though vertical, are well exposed and less deformed. At Cinnabar Mountain the formations splay out upward, so thickness measurements taken at the topographic base of the exposure will, in general, be less than thickness measurements taken higher. Most of our measurements were taken rather high on the exposure because here the beds are better exposed. (See "Measured Sections.")

The Gardiner area is isolated from other areas of sedimentary rock exposure and is near a State line where formation names traditionally change. Moreover, because Gardiner is west of the type areas for the Cretaceous formations and is closer to the source areas for clastic and volcanic components, some formations differ from the generally accepted norm in age, thickness, or lithology. Many names chosen will be controversial and doubtless some are incorrect. Nevertheless, it seemed better to use commonly accepted names for most 
formations rather than new ones for a small, isolated, and poorly exposed area. Only in the post-Eagle beds are new names introduced. Here a correlation with the newly established Livingston Group (Roberts, 1963) is suggested, but the two local formations are assigned new names.

\section{PALEOZOIC ROCKS}

\section{MADISON LIMESTONE}

The oldest Paleozoic formation exposed in the Gardiner quadrangle is the Mississippian Madison Limestone. Everywhere it is at least partly cut out by the Gardiner fault, and in most places it is missing entirely. The upper, massive part, called the Mission Canyon Limestone of the Madison Group in most parts of southwestern Montana, is all that is exposed here. Wilson $(1934 a, b)$ did not divide the Madison at Cinnabar Mountain but measured 1,100 feet total thickness and noted that the lower part is more thinly bedded.

In the Gardiner quadrangle the maximum exposed thickness of the Madison is about 500 feet. It crops out in three places as horses along the Gardiner fault and in a few small patches close to the fault in the deformed area south of Blanding Station (pl. 1). The formation is distinctive among the sedimentary rocks, for it is the only massive limestone. It is light to dark gray, is locally sandy, contains nodular chert in some beds, and is stained pink in places. In most outcrops it is fractured and the bedding attitude is difficult or impossible to determine. Its upper contact with the Amsden Formation is generally assumed to be an erosional unconformity, but the unconformity cannot be seen in the Gardiner area. No identifiable fossils were found.

\section{AMSDEN FORMATION}

The Amsden Formation of Pennsylvanian age is found only as deformed poorly exposed remnants in a few places within the drag zone along the Gardiner fault. Commonly it is sheared out completely. Its true thickness cannot be measured, and the formation cannot be studied in detail in the Gardiner area. It is recognized by its stratigraphic position and the red color of the soil in covered areas and by the intercalation of thin-bedded dolomite, siltstone, limestone, and mudstone where exposed.

Contact relations were not observed in the Gardiner area, but at Cinnabar Mountain the upper contact is conformable and the lower one is an erosional unconformity. (See "Measured Sections.")

Original thickness is probably variable owing to the unconformity at the base, and the thicknesses measured by different geologists will 
differ because of the uncertain location of the generally covered upper contact and the structural modifications at places like Cinnabar Mountain. We measured 143 feet at Cinnabar Mountain; Wilson (1934b) found 161 feet.

Fossil fragments occur near the top of the formation in a deformed outcrop in the SW1/4 sec. 19, T. 9 S., R. 9 E., but were not identified. As no Big Snowy Formation is known in the Yellowstone Park area, all rocks between the Madison Limestone and the Quadrant Quartzite are assigned to the Amsden Formation of Pennsylvanian age (Maughan and Roberts, 1967, p. B6).

\section{QUADRANT QUARTZITE}

The Quadrant Quartzite of Pennsylvanian age is a conspicuous resistant marker bed that can be used to help determine small discontinuous structures in overturned strata along a short segment of the deformed zone near the Gardiner fault (pl. 1). The Quadrant is exposed only in sec. 19, T. 9 S., R. 9 E., and sec. 24 , T. 9 S., R. 8 E., west of Bear Creek and north of the Yellowstone River. It is a white, light-gray, or yellowish-gray fine-grained quartzite, but in the Cinnabar Mountain area, where it is less deformed and less silicified, calcareous or dolomitic sandstone is intercalated with the dominant quartzite.

The basal contact is covered in most places, but where it is exposed it appears conformable. An abrupt change in lithology and an erosional unconformity mark the upper contact; a discontinuous basal conglomerate is present in the overlying formation at Cinnabar Mountain, and beneath that a bed 1-3 feet thick of apparently reworked Quadrant that contains fossil hash, carbonate cement, and scattered chert pebbles was noted in a few places.

Measured thicknesses at Cinnabar Mountain range from 125 to 176 feet, depending on where the measurement is taken and the choice of the basal contact. In the mapped area the thickness is unknown because of deformation and the indefinite attitude in most outcrops. All but 30 feet has been sheared out in places.

The name Quadrant is now restricted to the dominantly sandy or quartzitic part of the original formation (W. H. Weed in Hague and others, 1896). As originally defined, the formation included the Amsden Formation of current usage (Scott, 1935). The name Quadrant is used most commonly in southwestern Montana and in this area is preferred to the Wyoming name Tensleep because the type area of the Quadrant is only 10 miles from Gardiner and the Tensleep is quartzite at only a few places. The two formations are laterally equivalent and Pennsylvanian. No identifiable fossils were found. 


\section{PARK CITY FORMATION}

Sheared remnants of the Permian Park City Formation range in thickness from 10 to 65 feet and crop out discontinuously below the Quadrant Quartzite where the rocks are overturned in the highly deformed area in the $\mathrm{SW} 1 / 4$ sec. 19 , T. 9 S. R. 9 E. This formation is shown only in the enlarged geologic sketch map, plate 1 . The total length along the strike where remnants can be found is about 1,400 feet; in about 600 feet of that segment and in all external areas where the formation might be expected, it has been sheared out entirely by small thrust faults. Nowhere in the mapped area is Phosphoria Formation or Shedhorn Sandstone exposed.

Where exposed, the Park City Formation is dolomite or dolomitic limestone, brownish gray, brown weathering, generally thin bedded, and sandy or silty. The insoluble residue (silt and fine sand) makes up 25-45 percent, mostly angular quartz, but 10 percent of the residue may be chert and traces of micaceous minerals.

The original thickness of Permian rocks, which may have included tongues of lithologically different facies, and the top and bottom relations of the formation are unknown. In the same small deformed area, even the resistant Quadrant has been structurally thinned to 30 feet in places, and more than 1,000 feet of Permian, Triassic, and Jurassic formations were sheared out (pl. 1).

At Cinnabar Mountain a more complete section of Permian rocks is present. (See "Measured Sections.") The base of the formation is marked by a discontinuous conglomerate as much as 1.5 feet thick that contains black chert pebbles as much as 3 inches in diameter and subangular pebbles of Quadrant. These pebbles suggest an erosional unconformity at the base of the formation. The Permian rocks are divisible into two gross units, each of which is mappable at scales as large as $1: 24,000$. The lower unit, about 60 feet thick, is dominated by nodular tubular and bedded chert and phosphorite. This material is interlayered with and set in a matrix of calcareous and phosphatic sandstone and impure carbonate rock. The basal 60 -foot unit is interpreted here as a thin tongue of the Phosphoria Formation, admixed and interlayered with Shedhorn Sandstone and very little Park City Formation. Though Cressman and Swanson (1964, p. 547) showed a dominant Phosphoria lithology (which includes two tongues of Tosi Chert Member and the Retort Phosphatic Shale Tongue aggregating 35.7 feet, and only 31.0 feet of Shedhorn lithology split into four separate parts, the thickest of which is $11.3 \mathrm{ft}$. and almost half dolomite), they have used the term Shedhorn Sandstone to designate this interval of the Permian rocks. Use of the name Shedhorn 
conflicts with the system of nomenclature advocated by McKelvey and others (1959, p. 9-11).

Above the basal 60 -foot-thick unit is a thicker one dominated by carbonate rock similar to that described above in the Gardiner area. This entire unit, almost 100 feet thick where measured by us, was placed in the Triassic Dinwoody Formation by Peterson, Gosman, and Swanson $(1954$, p. 26$)$; most of it was placed in the Dinwoody by McKelvey and others (1959, p. 33) and Cressman and Swanson (1964, p. 547). Peterson, Gosman, and Swanson noted fossils at the base of the carbonate unit. Additional fossils collected from this zone have been identified as Permian by Ellis L. Yochelson (written commun., 1961).

The carbonate unit, which is definitely Permian at its base, is nearly continuous stratigraphically for 88 feet and then is overlain by a few feet of calcareous sandstone and siltstone before recognizable Dinwoody beds are found. (See "Measured Sections.") We place the Permian-Triassic boundary at essentially the same place chosen by Wilson (1934b) and Newell and Kummel (1942, p. 990). If the carbonate member of this report and the chert, phosphorite, and sandstone of Cressman and Swanson are combined, the total thickness for all rocks between the Quadrant and the Dinwoody is 158 feet.

Because carbonate rock is dominant at Cinnabar Mountain, the name Park City is preferred for the upper 96 feet. (See "Measured Sections.") If the entire Permian interval is to be mapped as a unit, then Park City is the preferred formation name, though it should be noted that a tongue of the Phosphoria Formation is present at the base.

No identifiable fossils, except those previously cited from the base of the carbonate unit, have been found above the chert-rich unit, but a zone containing abundant unidentifiable pelecypods is present in the conspicuous limestone ledge at the top of the carbonate rock and below the uppermost calcareous sandstone and siltstone. Further study of this ledge may reveal fossils useful in age determination.

\section{MESOZOIC ROCKS}

\section{DINWOODY AND CHUGWATER FORMATIONS}

The Lower Triassic Dinwoody and Chugwater Formations, mapped as a single unit in this report, crop out rarely and incompletely in sec. 19, T. 9 S., R. 9 E. (pl. 1). Both formations are nonresistant and in most places are sheared out entirely by thrust faults in the drag zone of the Gardiner fault. The zone of Triassic rock is generally red, but the bleached top and the gray. (Dinwoody Formation) base were identified in a few places, 
The best exposure in the region is at Devils Slide near Cinnabar Mountain (fig. 1). The conspicuous red stripe, visible from U.S. Highway 89 northwest of Gardiner, gave Cinnabar Mountain its name. This section was measured in detail by Newell and Kummel (1942, p. 990). Our measured section is not repeated because it agrees closely with theirs. At Devils Slide the Dinwoody Formation is 62 feet thick and is dominated by gray, greenish-gray, and brownish- or yellowish-gray siltstone and shale. Thin laminated dolomite beds occur near the top and the base and probably elsewhere in the section. Thin gypsum beds are present at several horizons.

The overlying Chugwater Formation is 95 feet thick and is also dominated by siltstone and shale. Only the basal 40 feet is typical red beds. The upper part has been bleached; it is gray, greenish gray, or grayish orange, is generally covered, forms a light-brown soil, and contains some fine sandstone.

Imlay, Gardner, Rogers, and Hadley (1948, sec. 24 and text) tentatively assigned 81 feet of sandstone immediately over the Chugwater to the Triassic. Wilson (1934b) placed the sandstone in the Jurassic. An unconformity between the Chugwater Formation and the overlying sandstone is suggested by the thick bleached zone at the top of the very thin red-bed section and by glauconite in the overlying sandstone. A study of the literature (Condit, 1918; Gardner and others, 1945, 1946; Imlay and others, 1948; Kummel, 1954; McKee and others, 1956, 1959; Witkind and others, 1964) indicates that a regional erosion interval removed between 200 and 600 feet of Lower Triassic red beds from the Cinnabar Mountain area before the overlying sandstone was deposited. Thus, the sandstone is assigned to the Jurassic in this report.

\section{ELIIS GROUP}

In the mapped area all marine Jurassic rocks are mapped as a single unit, the Ellis Group (undivided). This is because the Ellis is sheared and deformed in the drag zone of the Gardiner fault so that individual formations within it cannot be recognized consistently or mapped. In most places the Ellis is sheared out entirely or covered, but it does crop out in four isolated patches between Eagle and Bear Creeks, sec. 24, T. 9 S., R. 8 E., and sec. 19, T. 9 S., R. 9 E. (pl. 1). The entire group, which contains the Sawtooth (equivalent to Piper Formation of northern and eastern Montana), Rierdon, and Swift Formations, was deposited in this region, for at Cinnabar Mountain the separate formations can be recognized and mapped. Remnants of each formation present at Cinnabar Mountain can 
be identified locally in the Gardiner area, and the exposure near Eagle Creek is nearly complete.

In the mapped area the indicated thickness, modified by structural thinning, ranges from 0 to 350 feet. The Ellis can be recognized by an abundance of calcareous shale or shaly limestone, fossils, and glauconite. Glauconite is most abundant in the calcareous fine-grained to conglomeratic sandstone (Swift) locally present at the top, but some glauconite is also present in the one exposure of sandstone at the base. The thick and conspicuous basal sandstone is exposed only near Eagle Creek, where it is silicified and in fault contact with Quadrant Quartzite.

Lenses of chert-pebble conglomerate have been found in the easternmost exposure of the Ellis (pl. 1). Some conglomerate occurs at the base of that exposure, but because of intense shearing the true stratigraphic position of the "basal" conglomerate is unknown. All of it may be in the uppermost sandstone (Swift), which definitely contains chert pebbles. Locally some shaly beds (Sawtooth) near the base of the Ellis are light red, the color typical of the correlative Piper and Gypsum Spring Formations in other areas.

In this. report the basal sandstone, 81 feet thick at Cinnabar Mountain, is considered an atypical part of the Sawtooth Formation because it is glauconitic and occurs above the pre-Ellis unconformity. (See discussions of Dinwoody and Chugwater Formations.) If the basal sandstone is included, the total thickness of the Ellis Group at Cinnabar Mountain is about 520 feet. (Compare Wilson, 1934b; Imlay and others, 1948; and "Measured Sections," this report.)

The Sawtooth Formation is considered Middle Jurassic and the Rierdon and Swift Formations are considered Upper Jurassic by Imlay, Gardner, Rogers, and Hadley (1948). The upper part of the Swift has been reworked by streams so that secondhand glauconite is locally present in the base of the nonmarine Morrison Formation. Thus, the Ellis Group is bounded above and below by unconformities, but the upper unconformity is minor.

\section{MORRISON FORMATION}

The Upper Jurassic Morrison Formation crops out in three small patches between Eagle and Bear Creeks in sec. 24, T. 9 S., R. 8 E., and sec. 19, T. 9 S., R. 9 E. (pl. 1). The formation has been thinned by squeezing and subsidiary faulting in the drag zone of the Gardiner fault and has been sheared out entirely in most places. It can be recognized by its stratigraphic position directly below the basal conglomerate of the Cloverly Formation and directly above the 
upper glauconitic sandstone of the Ellis Group and by its own characteristic highly variable lithology.

The variegated color of the Morrison shales and siltstones, the interbedded sandstones, particularly in the upper part, and a few thin beds of fresh-water limestone are characteristic. In the Gardiner area the formation is poorly exposed and no attempt was made to study it in detail. A detailed section 319 feet thick was measured at Cinnabar Mountain. (See "Measured Sections.") The carbonaceous and coaly beds found near the top at Cinnabar Mountain do not crop out in the mapped area.

The formation is bounded by a slight erosional unconformity at the base and by a thick and conspicuous conglomerate in the overlying Cloverly Formation. The unconformity at the top is more significant than the one at the base or than any of the many intraformational unconformities within the nonmarine Morrison. No identifiable fossils were found.

\section{CLOVERLY FORMATION}

In the mapped area the Lower Cretaceous Cloverly Formation is exposed only in the highly deformed drag zone of the Gardiner fault in sec. 24 , T. 9 S., R. 8 E., and sec. 19 , T. 9 S., R. 9 E. (pl. 1), where it has been reduced to one-third or less of the original thickness by shearing out of the nonresistant middle member and, in places, the upper member. In all places where the formation can be identified, at least part of the basal conglomeratic member is present. Descriptions that follow are abstracted mostly from the measured section, 360 feet thick, at Cinnabar Mountain. (See "Measured Sections".)

The Cloverly Formation is characterized by resistant sandstone members at base and top separated by a much thicker middle member that contains many different rock types of many different colors. The basal sandstone and conglomerate member, the resistant ledgeforming part of which is generally about 25 feet thick, is light to dark gray and weathers brown. Everywhere it contains lenses of dominantly black chert-pebble conglomerate. The pebbles average about half an inch in diameter, but are as much as 3 inches in diameter, and are most abundant at the base. The sandstone grades upward through a nonresistant zone about 8 feet thick to siltstone and mudstone which is locally conglomeratic. The basal conglomeratic sandstone is the most resistant and most useful marker bed in the highly sheared area. A thin unmappable strip can be found in places where all the rest of the formation, along with other formations, has been sheared out completely. 
The middle member of the formation at Cinnabar Mountain is 240 feet thick and is generally nonresistant, but in the Gardiner area it is poorly exposed or sheared out entirely. Near the top of this highly variable middle unit is a 20 -foot-thick medium-gray massive finely crystalline limestone that contains gastropods and ostracodes. This limestone probably is the "gastropod limestone" which marks the top of the partly correlative Kootenai Formation of western Montana; but, because the limestone was not found in the mapped area and because the gastropods are rather inconspicuous at Cinnabar Mountain, the well-defined and more inclusive Cloverly Formation was used as the map unit.

The upper sandstone member contains medium-gray medium- to fine-grained crossbedded ripple-marked quartzitic sandstone lenses that generally weather yellowish or brownish gray and form a conspicuous ledge in most areas. Where measured at Cinnabar Mountain, this ledge, which contains a few interbeds of dark-gray or black shale, is 87 feet thick. Some of the sandstone beds are conspicuously and abruptly lenticular so that measurements elsewhere will not give the same bed thicknesses. Probably the overall thickness of the upper member is also variable. Near Gardiner, for structural or possibly for stratigraphic reasons, the upper sandstone is thinner. Everywhere the upper contact with black Thermopolis Shale is abrupt.

The Cloverly is Lower Cretaceous. Except for the gastropods and ostracodes previously noted, no fossils were found. The formation is probably nonmarine from the base through the "gastropod limestone"; above, the intercalated dark-gray shale indicates a marine origin.

\section{THERMOPOLIS SHALE}

In the mapped area the Lower Cretaceous Thermopolis Shale is exposed only in the highly deformed drag zone of the Gardiner fault in the SW1/4 sec. 19 , T. 9 S., R. 9 E. (pl. 1), where it has been thinned to a fraction of its original thickness and cannot be studied in detail. In most places the formation has been sheared out. The description below is abstracted from the measured section at Cinnabar Mountain, where the Thermopolis is 394 feet thick. (See "Measured Sections.")

The Thermopolis is divisible into two members that were not mapped separately. The shale member at the base is composed of about 70 percent shale and 30 percent interbedded sandstone or siltstone and is 280 feet thick at Cinnabar Mountain. The shale is overlain by the Muddy Sandstone Member, 114 feet thick. 
The shale of the Thermopolis is dark gray or black and fissile or platy and is interbedded with nonresistant thin-bedded fine-grained sandstone or siltstone that weathers to a rusty color. Both shale and sandstone contain worm trails and carbonaceous flecks. The basal contact, marked by a strong topographic and lithologic break at Cinnabar Mountain, is generally abrupt and easy to find, but an intergradation is indicated by subordinate black shale in the Cloverly and subordinate sandstone in the Thermopolis. There is no evidence for an unconformity.

The Muddy Sandstone Member is split into two unequal parts by a 34-foot-thick shale bed. The lower sandstone, 27 feet thick, is similar to sandstones in the shale member. The upper part of the Muddy, 54 feet thick at Cinnabar Mountain, is quite variable; but generally the upper 21 feet, which is the most conspicuous part, is light gray, medium grained, locally fine grained, very locally coarse grained and conglomeratic near the top, thin bedded to laminated, crossbedded, and calcareous. Most of the Muddy may also be described as salt-and-pepper sandstone, a type very common in Cretaceous formations of the region and probably a mixture of dark chert and light quartz grains. Local conglomerate at the top indicates a slight erosional unconformity between the Muddy and the overlying Mowry Shale. In all other respects the two formations appear conformable.

The Thermopolis Shale and the Muddy Sandstone Member correlate approximately with units bearing the same names in various parts of Wyoming and Montana and with similar units generally considered part of the Colorado Shale in other parts of Montana. In the report area the base of the Thermopolis was chosen to give the best possible mapping horizon (see Cloverly Formation) and to agree as closely as possible with current practice in areas to the south (Love, 1956, p. 77). In some other areas the sandstone member at the top of the Cloverly, as defined in this report, is included in the Thermopolis, and the "gastropod limestone" or some bed above it is chosen as the top of the Kootenai Formation.

The upper contact is also controversial in some areas, particularly in the Bighorn Basin. Some geologists include the soft black shales immediately above the Muddy and below the siliceous Mowry Shale in the Thermopolis. In many parts of Wyoming and in the Gardiner area, the only mappable contact is the top of the Muddy or Newcastle Sandstone.

\section{MOWRY SHALE}

The Lower Cretaceous Mowry Shale rests with a slight erosional unconformity on the Muddy Sandstone Member of the Thermopolis 
Shale and grades abruptly into the overlying sandstone of the Frontier Formation. In the mapped area the formation is exposed only in the SW $1 / 4$ sec. 19 , T. 9 S., R. 9 E., where it is highly deformed and difficult to define. In most places it has been sheared out. The description below has been abstracted from the measured section at Cinnabar Mountain, where the formation is 324 feet thick. (See "Measured Sections.")

The measured section is unsatisfactory because more than half is covered. From float and inadequate exposures the formation appears to be dominated by black platy siliceous shale that weathers black with rusty stains or has a thin very light gray weathered coating. Thin gray or light-olive-gray fine- to medium-grained laminated quartzitic sandstone beds are distinctly subordinate. South of the mapped area along the Gardner River, a 2-foot-thick bed of greenishgray bentonite that contains cream-colored porcellanite lenses is intercalated with the black shale, and other bentonite or porcellanite beds probably could be found in a complete exposure. Fish scales common in the Mowry of other areas were found only in the Gardner River exposure. No other fossils were found.

Current practice places the upper boundary of Lower Cretaceous rocks at the top of the Mowry where that formation can be identified. The Mowry has been identified 40 miles north by Albert E. Roberts (oral commun., 1964).

\section{FRONTIER FORMATION}

The Upper Cretaceous Frontier Formation crops out in deformed and incomplete exposures between Eagle and Bear Creeks in sec. 24, T. 9 S., R. 8 E., and sec. 19, T. 9 S., R. 9 E., just north of the park boundary and near the Gardiner fault just south of the Yellowstone River. At Cinnabar Mountain the formation is 497 feet thick, but in the mapped area it is structurally thinned or sheared out. The Frontier is bounded at base and top by sandstone members about 55 feet thick, but in most places in the mapped area only the upper sandstone is exposed. Throughout the mapped area and south of it along the Gardner River, but not at Cinnabar Mountain, this sandstone is overlain by a distinctive porcellanite. The association of sandstone and porcellanite is so striking that it can be used as a key horizon to work out the complex structure in the drag zone of the Gardiner fault. Stratigraphic details for the Cinnabar Mountain area are given in the measured sections.

Everywhere the upper sandstone member is the most conspicuous and resistant part of the formation. One of the best exposures is south of the mapped area in an abandoned quarry between the high- 
way and the Gardner River below the town of Mammoth, Wyo. Here and in the mapped area the upper member is light gray, locally brown weathering, medium grained, and locally crossbedded and has a salt-and-pepper appearance; frosted and rounded grains are common, and the sand is well sorted.

No fossils were found in this area, but the formation probably correlates in part with the much thicker formation of the same name in western Wyoming and with the Frontier Formation 40 miles north of Gardiner (Albert E. Roberts, oral commun., 1964). The Frontier is presumed to be the first formation in the thick Upper Cretaceous section of the region.

\section{CODY SHALE}

The Upper Cretaceous Cody Shale is poorly and incompletely exposed and highly deformed in the mapped area. Discontinuous structurally thinned patches are found northeast of Gardiner and southwest of the Gardiner fault in a southeast-trending belt 1.5 miles long. Nowhere in the mapped area can the formation be studied or measured in detail, but exposures are better on the southeast spur of Cinnabar Mountain and along the southwest face of Mount Everts (3-5 miles southeast of Gardiner).

We did not measure the Cody, but consideration of available data from the Mount Everts section (Fox, 1939; Brown, 1957) suggests that the stratigraphic interval measured by Fox and revised by Brown is about 1,260 feet. This includes at least 162 feet of sandy beds at the top, which we place in the overlying Telegraph Creek Formation. Therefore, the thickness of the Cody Shale of this report is about 1,100 feet. (Compare Wilson, 1934b, p. 370; Bauer, 1948, p. 34.) The generalized description below is modified from the above sources to emphasize differences within the mapped area.

The lower 150-200 feet of the Cody is mostly dark-gray or black shale that contains numerous thin bentonite beds, a few limestone concretions, and, near the base, a few thin sandstone beds. Throughout the mapped area and for at least 1.5 miles south along the Gardner River a distinctive light-gray, pink-spotted porcellanite marks the base. The softer bentonite beds above this are rarely seen in the mapped area.

The upper 900-950 feet is a mixture of shale, sandy shale, siltstone, and thin-bedded sandstone. Shale is dominant. The sandstone is glauconitic only near the middle. The top, which is rarely exposed, is picked arbitrarily where sandstone occurs in beds less than 5 feet apart or where sandstone becomes persistently dominant. The overlying Telegraph Creek Formation, transitional between the shale 
below and the massive sandstone above, is more yellowish than the gray Cody.

The name Cody Shale was originally used only in the Bighorn Basin and for shale beds bounded at the base by the sandy Frontier Formation and at the top by massive sandstone of the Mesaverde Formation. Subsequently, the name has been used in other areas to include thicker shale sections of different ages that have different sandstone formations at the top. Within the Bighorn Basin, changes at the top are almost as great as changes outside the basin (Love and others, 1951, sheet 2; Horn, 1963). We, therefore, accept the name Cody as valid here, even though the overlying Telegraph Creek Formation and at least part of the Eagle Sandstone at Gardiner are time equivalents of the upper part of the Cody in much of the Bighorn Basin.

The age of the Cody in the Gardiner area, early and middle Niobrara, is equivalent in part to that in Jackson Hole, Wyo., and in the type area. Fox (1939) described microfossils that establish a correlation between the base and the Fort Hays Limestone Member of the Niobrara Formation of Kansas. Three megafossils of middle Niobrara age, Scaphites binneyi Reeside?, Inoceramus involutus Sowerby, and I. stamtoni Sokolow, were found in the middle part of the section at Cinnabar Mountain, and a common middle and late Niobrara form, Crassatella andrewsi Henderson, was found 0.7 mile east of Gardiner where stratigraphic position is unknown (W. A. Cobban, written commun., 1961). The upper part of Fox's Cody Shale (Haplophragmoides calcula zone) was placed in the Telegraph Creek Formation in this report on the basis of lithology.

\section{TELEGRAPH CREEK FORMATION}

The Upper Cretaceous Telegraph Creek Formation crops out sparsely and incompletely on both sides of the Yellowstone River about $1 \frac{1}{2}$ miles east of Gardiner and more completely along the east side of the Gardner River near Eagle Nest Rock (pl. 1). The base is covered in the mapped area so that the thickness of the formation, which probably varies, is unknown. We measured only the upper 124 feet. (See Mount Everts measured section 4.)

The Telegraph Creek Formation is transitional between the dominantly shaly beds below and the thick massive Virgelle Sandstone Member of the Eagle Sandstone above. Both contacts are gradational. Because the sandstone increases irregularly up section in the Cody Shale, an arbitrary contact with the Telegraph Creek is necessary. In this report we assign an estimated 250-350 feet to the Telegraph Creek. Well-defined sandstone beds are dominant and 
generally less than 5 feet apart. The Telegraph Creek by the above definition includes at least 162 feet of Cody Shale as that formation was defined by Fox (1939, p. 24, 92, 93). Structure and poor exposure make the Telegraph Creek the most difficult formation to find and to map. In many areas it is sheared out or covered.

The basal 140 feet or more is conspicuously banded owing to interbedding of dark-gray sandy shale and lighter yellowish gray sandstone. The fine-grained calcareous sandstone occurs in laminated and cross-laminated beds no more than 10 inches thick in most areas, and the shale or siltstone is commonly in thinner beds. A bluff-forming laminated to thick-bedded sandstone 20-25 feet thick that has only sparse shale laminae marks the base of the upper 80 feet of the Telegraph Creek where we measured it. This upper part is mostly nonresistant thin-bedded laminated and cross-laminated sandstone that forms a grass-covered slope marked by a few sandstone ledges. The sandstone weathers to thin curved plates that set it apart from the overlying much more resistant and massive Virgelle Sandstone Member.

Though we found no fossils, the age of the Telegraph Creek is well established because the mint is bounded above and below by well established because the unit is bounded above and below by lophragmoides calcula zone, which we place in the Telegraph Creek in the Gardiner area, is of Niobrara age and is correlative with the upper part of the Cody in the Bighorn Basin.

\section{EAGLE SANDSTONE}

Patches of the Upper Cretaceous Eagle Sandstone are exposed from Gardiner southeast to the edge of the mapped area in the drag zone of the Gardiner fault, but faulting has thinned the section and surficial cover further obscures the stratigraphic details. Part of the Eagle is exposed between the Gardner River and Mount Everts on the south edge of the area ( $\mathrm{pl} .1$ ). Where measured, about 0.6 mile south of the mapped area on the west face of Mount Everts, the formation is 777 feet thick. (See "Measured Sections.") All potentially valuable coal occurs in the Eagle Sandstone.

The Eagle can be divided into two members. The lower one is the bluff-forming Virgelle Sandstone Member recognizable throughout much of Montana. The upper and much thicker part is called the coal member in this report. The two members were mapped as one unit.

From a distance the Virgelle appears massive, but in many outcrops weathering has exposed thin beds or laminae, which commonly are cross-stratified and occur as units that have a thick-bedded ap- 
pearance. In places the high bluff is split by a thin-bedded nonresistant sandstone zone. The Virgelle is light or medium gray to light olive gray, has a salt-and-pepper appearance, and is commonly tinted or stained yellow and brown by limonite. Most of the sandstone is fine to medium grained, angular, arkosic, and calcareous. Locally near the top there are coarse-grained lenses and very locally scattered granules or pebbles of chert. Dark minerals, among which biotite is most conspicuous, make up about 10 percent. The member grades downward, by a decrease in bed thickness and by intercalation of shale, into the less resistant Telegraph Creek Formation; it grades upward, by a decrease in bed thickness and by intercalation of carbonaceous shale, into the less resistant coal member. In most places a thin coal bed occurs at or near the top. Where measured on Mount Everts the Virgelle is 163 feet thick, but data from the Electric coal field (fig. 1), 5 miles northwest of Gardiner, indicate a highly variable thickness ranging from about 90 feet to 160 feet.

The coal member is characterized by interbedded sandstone, shale, carbonaceous shale, and coal. Nearly all the sandstone is calcareous. The sandstone occurs in lenticular highly variable units generally less than 20 feet thick and is not as well sorted as the Virgelle. One sandstone zone, locally as thick as the Virgelle, forms a discontinuous bluff that looks like Virgelle in some outcrops. The base of this zone is 180 feet above the Virgelle where measured on Mount Everts; but the stratigraphic position of the zone, like its thickness, is variable, and in places the zone is divided into several thin sandstones by intercalation of shale and carbonaceous shale. A lenticular sandstone unit, commonly about 20 feet thick and underlain or intercalated by thin coal beds, marks the arbitrary top of the member and of the formation in and south of the mapped area. Locally, this and other fairly thick sandstones contain marine or brackish-water fossils (table 1).

Between the principal sandstone units the formation is dominantly carbonaceous shale and coal, but thin lenticular sandstones are also present, and some are prominent locally. In general, the notable coal zones occur above strong sandstone ledges, and in the Electric coal field the best coal zone is at or near the top of the thick medial sandstone. The upper part of the member is less carbonaceous than the lower. The coal, which is thin, lenticular, and variable in quality, is discussed under "Economic Geology."

The arbitrary upper contact, commonly covered and difficult to locate, separates the coal member from the Everts Formation; the Everts contains no discrete coal beds directly above the contact and very few thin coal beds elsewhere and is much less carbonaceous in 
general. In addition, the sandstone unit at the top of the Eagle generally is overlain by mudstone devoid of thick sandstone beds. Finally, the Eagle has an overall yellowish tint that contrasts with the grayness above. In spite of these differences the contact is gradational, for in one place (Mount Everts measured section 3) an Eaglelike sandstone containing marine fossils was found about 150 feet above the contact, and in the Electric coal field carbonaceous shale or mudstone that contains very thin coal seams persists as much as 850 feet above the Virgelle. On Mount Everts where the Eagle was measured the thickness of the coal member is 614 feet.

In the Gardiner area the Eagle Sandstone is older than in central Montana. This is in accord with the west-to-east change in age of homotaxial or lithologically equivalent sandstone units of the Upper Cretaceous in Montana and Wyoming (Tourtelot and others, 1960, p. B447). In general, the sandstones become younger to the east. In the Gardiner area the Eagle is of Niobrara age. From a study of the pelecypods listed in table 1, W. A. Cobban (written commun., 1961) concluded that the top of the Eagle in the Gardiner area is no younger than the base of the Eagle in central Montana and may be even older.

In addition to the pelecypods, which have been found only in sandstones, the Eagle contains land-plant debris in all rock types and a distinctive pollen and spore flora in the coaly zones. None of the plant material is precisely diagnostic, though study of some does suggest an early Late Cretaceous age (R. H. Tschudy, written commun., 1963); and the plant material's association with marine and brackish-water shells, some of which are reworked, indicates that the Eagle was deposited in a mixed continental and marine environment.

The Eagle Sandstone in the mapped area is essentially homotaxial with the Eagle of the Livingston area 40 miles north and is about the same thickness (Roberts, 1957, p. 43, 47; 1963, p. B90). It also resembles the much thicker Bacon Ridge Sandstone and "coaly sequence" of the Jackson Hole area (Love, 1956, p. 80, 81). Paleontologic evidence suggests that the rocks in Jackson Hole are at least partly the same age as the Eagle Sandstone in the Gardiner area.

The Eagle Sandstone is a regressive deposit, for it is underlain by marine beds and overlain by continental beds. There are oscillations, however, in which marginally marine beds, chiefly beach or nearshore sandstones, are overlain by nonmarine coal-swamp deposits. Such couplets are individually regressive, and they imply intervening episodes of transgression. The transgressive episodes are not clearly defined because marine shale seems not to have been deposited 
TABLE 1.-Pelecypods from Eagle Sandstone near Gardiner, Mont.

[Identifications by W. A. Cobban, U.S. Geol. Survey]

\begin{tabular}{|c|c|c|c|}
\hline $\begin{array}{l}\text { USGS } \\
\text { Mesozoic } \\
\text { loc. No. }\end{array}$ & Location & $\begin{array}{l}\text { Lithology, stratigraphic } \\
\text { position, and origin }\end{array}$ & Pelecypods \\
\hline D2880 & $\begin{array}{l}\text { East of mouth of } \\
\text { Gardner River } 1.05 \\
\text { miles, on south bank } \\
\text { of Yellowstone } \\
\text { River. }\end{array}$ & $\begin{array}{l}\text { Uppermost sand- } \\
\text { stone, nearshore } \\
\text { marine. }\end{array}$ & $\begin{array}{l}\text { Cymbophora } \\
\quad \text { arenaria (Meek). }\end{array}$ \\
\hline D2881_--- & $\begin{array}{l}\text { East of mouth of } \\
\text { Gardner River } 0.9 \\
\text { mile, on south bank } \\
\text { of Yellowstone } \\
\text { River. }\end{array}$ & $\begin{array}{l}\text { Sandstone near top, } \\
\text { marine beach. } \\
\text { All reworked. }\end{array}$ & $\begin{array}{l}\text { Inoceramus sp.; } \\
\text { Crassostrea cf. C. } \\
\text { soleniscus (Meek); } \\
\text { Anomia sp. }\end{array}$ \\
\hline D2882 & - do do & $\begin{array}{l}\text { Uppermost sand- } \\
\text { stone } 18 \mathrm{ft} \text { higher } \\
\text { than above, } \\
\text { mostly nearshore } \\
\text { marine. }\end{array}$ & $\begin{array}{l}\text { Inoceramus sp., } \\
\text { possibly I. } \\
\text { platinus Logan; } \\
\text { Ostrea coalvillensis } \\
\text { Meek; Cymbophora } \\
\text { arenaria (Meek)? }\end{array}$ \\
\hline D2883_... & $\begin{array}{l}\text { North bluff of Yellow- } \\
\text { stone River, SW1/4 } \\
\text { sec. 24, T. } 9 \text { S., R. } \\
8 \text { E. }\end{array}$ & $\begin{array}{l}\text { Sandstone near base } \\
\text { of coal member, } \\
50 \mathrm{ft} \text { above first } \\
\text { coal, marine } \\
\text { beach. All trans- } \\
\text { ported and mixed } \\
\text { by current along } \\
\text { shore. }\end{array}$ & $\begin{array}{l}\text { Inoceramus sp.; } \\
\text { Ostrea } \text { sp.; } \\
\text { Brachidontes sp.; } \\
\text { Cymbophora } \\
\text { arenaria (Meek); } \\
\text { Corbula } \text { sp. }\end{array}$ \\
\hline & $\begin{array}{l}\text { East of Gardner River } \\
2.6 \text { miles on south } \\
\text { edge of Gardiner } \\
\text { quadrangle. }\end{array}$ & $\begin{array}{l}\text { Sandstone, probably } \\
\text { near top, mar- } \\
\text { ginally marine. }\end{array}$ & Ostrea sp. \\
\hline-- & $\begin{array}{l}\text { Eagle Nest Rock on } \\
\text { Gardner River. }\end{array}$ & $\begin{array}{l}\text { Top of Virgelle } \\
\text { Sandstone Mem- } \\
\text { ber, marginally } \\
\text { marine. }\end{array}$ & $\begin{array}{l}\text { Ostrea sp. (probably } \\
\text { same species as } \\
\text { above). }\end{array}$ \\
\hline
\end{tabular}

after Telegraph Creek time, and the lower (transgressive) and upper (regressive) parts of any sandstone unit are practically inseparable. The Gardiner area was marginal to the sea and mostly continental during Eagle time so that in cross section only the landward apices of transgressive-regressive nearshore sandstones, separated by continental deposits, are present (Sears and others, 1941, fig. 20). Sands derived from the west continued to be deposited irregularly eastward over younger and still younger marine beds, thus explaining the age change from west to east. 


\section{EVERTS FORMATION}

The upper Cretaceous strata that overlie the Eagle Sandstone gradationally and underlie the Landslide Creek Formation unconformably are here named the Everts Formation for exposures on Mount Everts southeast of Gardiner (fig. 1) and south of the quadrangle. The formation is about 1,250 feet thick and is characterized by interbedded light-colored lenticular sandstone and medium- to light-gray mudstone, which is locally greenish, yellowish, or brownish, especially near the top. Though no discrete beds of bentonite were found, some mudstone probably contains an altered volcanic-ash component. Very locally near the base the Everts contains shallowwater marine pelecypods; very locally near the top it contains freshor brackish-water pelecypods and gastropods. Poorly preserved landplant debris is sparsely present in many parts, and thin lignite seams can be found locally near the base and top. One thin coal lens was found locally near the top in the mapped area. This extremely variable formation is believed to be mostly nonmarine.

The lower one-third to one-half of the formation is nonresistant and generally covered and is dominated by gray mudstone (locally green or brown and carbonaceous) which contains about 20 percent interbedded lenticular sandstone. Generally, the sandstone is fine grained and in units less than 30 feet thick. Calcareous concretions are present locally in this and other parts of the formation. A medial or upper zone of variable thickness dominated by light-gray to white fine- to medium-grained calcareous crossbedded highly lenticular ridge-forming sandstone is present in nearly all areas. The discontinuous ridges commonly weather to rounded forms. Sandstone beds of this type are present locally to the top of the formation and even into the overlying formation, but in many areas the upper one-fourth of the Everts Formation is composed of nonresistant darker thinbedded sandstone and claystone.

The upper contact, which is rarely exposed, is an erosional unconformity which has a known local relief of 50 feet. Absence of the upper nonresistant zone in some areas probably indicates deeper erosion. In many areas coarse or conglomeratic sandstone is exposed directly above the unconformity. Nearly everywhere sandstone above the unconformity is darker and coarser than that below, and the claystone above is darker or more bentonitic or both.

The Everts Formation is about 1,250 feet thick. (See "Measured Sections.") Because of extreme local variability and poor exposure, no type section is designated; but the type area, from which the measurements and descriptions were taken, is the west half of the 
northern projection of Mount Everts. This area extends northward about $21 / 2$ miles from the Wyoming-Montana State line nearly to the Yellowstone River. The formation is also exposed further south, on the top and the west and east sides of Mount Everts. Lenticular hogbacks 200-1,000 feet long, which reflect the medial or upper sandstone zone, are present south of the quadrangle on the upper east side of Mount Everts. A fragmentary overturned section is present under basalt and talus northwest of Gardiner (pl. 1). In the Electric coal field, 5 miles northwest of Gardiner, only the lower part was found, and it is poorly exposed; it is more carbonaceous than the formation at Mount Everts and is difficult to separate from the Eagle Sandstone.

Probably most of the Everts Formation correlates with the Cokedale Formation of the Livingston Group (Roberts, 1963, p. B89; 1965 , p. B56), which would make it early Campanian in age. However, there are lithologic differences: the Everts contains no coarse volcanic components, and the Cokedale has no marine elements. The two formations were derived from different sources and deposited in separate basins. The base of the Everts may be late Niobrara (Santonian) in age, for it grades into the Eagle Sandstone, here of Niobrara age, and contains generically similar though nondiagnostic shallow-water marine pelecypods-Ostrea sp. and Cymbophora sp. cf. $C$. utahensis Meek (W. A. Cobban, written commun., 1961)-in the one definitely marine zone near the base. Near the top, freshor brackish-water Corbula sp., locally abundant in two thin beds, and a smooth high-spired gastropod are also nondiagnostic of age. Lithologically the Everts also resembles the "lenticular sandstone and shale sequence" of Jackson Hole (Love, 1956, p. 81).

Though the Everts Formation probably correlates in part with the Claggett Shale and the Parkman Sandstone, as suggested by Wilson's (1934b) nomenclature for the Gardiner area, these names were rejected because the formations are not homotaxial with the Gardiner rocks and are much different in origin, lithology, and thickness. Probably most of the Everts was deposited as the continental part of a marine delta that had been built higher than sea level. Lagoonal, paludal, and fluvial deposits are mixed. Lenticular white sandstone beds are probably fluvial channel sands, though some may be fresh- or brackish-water beach deposits. Intervening mudstones are probably flood-plain deposits. Most of the sediments are presumed to have come from a rising landmass to the west. The area was well drained, because coal and carbonaceous shale are rare. Volcanoes must have been some distance away during Everts time, but nearby volcanic activity was common immediately thereafter. 


\section{LANDSLIDE CREEK FORMATION}

The youngest Cretaceous formation in the area is here named the Landslide Creek Formation for exposures near Landslide Creek 2 miles west of Gardiner. The formation rests with erosional unconformity on the Everts Formation and is bounded at the top by a major angular unconformity that marks the end of known Cretaceous deposition in the area. The formation, which is wholly continental in origin (mostly fluvial), comprises a sequence of dark-colored commonly conglomeratic sandstone interbedded with varicolored generally somber mudstone and claystone. A conspicuous volcanic component is present in all grade sizes: bentonite is present in virtually all fine-grained rock and in some coarse-grained rock; andesitic grains are common in nearly all sandstone and conglomerate; andesitic pebbles, cobbles, or boulders, which are rare or absent near the base and in the eastern part of the area, increase irregularly in abundance and average coarseness up section and northwestward in the area. Fragments of dinosaur bones are present locally, and landplant debris is common throughout. The name Landslide Creek Formation is singularly appropriate, for in the southwest corner of the mapped area are huge Quaternary landslides in which plastic bentonite from this formation was the medium for the transportation of debris from it and younger formations (Waldrop and Hyden, 1963, p. E13).

Only structurally and geographically isolated partial sections are exposed (table 2). Precise relations between the different exposures are unknown so that the aggregate thickness, even of exposed rocks, is unknown. Exposed parts can be no less than 1,300 feet thick, and one interpretation permits a thickness of 2,300 feet in the western part of the area. The actual thickness, which includes buried parts in the valley of the Yellowstone River, is probably greater.

Exposures are found in four areas, in each of which a partial section has been measured: (1) on and just north of Mount Everts, (2) $1 \frac{1}{2}-3 \frac{1}{2}$ miles northwest of Gardiner along the mountain front nearly to Little Trail Creek (partly in Miner quadrangle; fig. 4), (3) the Landslide Creek area in the southwest corner of the mapped area, and (4) at the north end of a topographic nose 4 miles northwest of Gardiner and just east of Reese Creek (Miner quadrangle). As none of these is complete or completely representative, no type section is designated. The type area is the composite of the four small areas.

In the few areas on Mount Everts where the base of the Landslide Creek is well exposed, a peculiar yellow or olive-drab very 
coarse grained and locally conglomeratic sandstone generally about 1 foot thick marks the base of the formation. This gritty friable material, which has a clay matrix, mantles an irregular erosion surface that clearly separates the Landslide Creek from the Everts Formation. Coarse sandstone and conglomerate have not been found near the contact in the underlying Everts. Conglomerate or coarse sandstone is thus a prime criterion for separation of the formations in the generally covered contact areas. In some areas light-colored fine- to medium-grained sandstone like that in the Everts appears in the lower part of the Landslide Creek Formation, above the lowest conglomerate or coarse sandstone. Thus, separation is difficult if the area is partly covered. In this sense the contact is gradational, even though an erosional unconformity exists.

Gray, greenish-gray, or olive-drab fine-grained to conglomeratic sandstone that weathers to various shades of brown characterizes arenaceous parts of the formation. Much sandstone is lenticular, crossbedded, feldspathic, chloritic, andesitic, and biotitic. Cement is clay, calcite, silica, chlorite, iron oxides, and zeolites. Some rocks are tough and hard and others are friable. Chert and quartzite granules and pebbles, in disseminations and lenses, are common in many beds. In the Mount Everts area and elsewhere in the lower part of the formation, andesitic pebbles are rare and no thick lenses of coarse volcanic debris were found. Thick lenses of andesitic pebbles, cobbles, and even small boulders occur within 450 feet of the base (fig. 4) 31/2 miles northwest of Gardiner. Heulandite grains and veinlets, common at the top of the formation, are present locally in lesser quantity in coarse volcanic debris wherever it is found. In the Landslide Creek area, andesitic pebbles and cobbles occur in the lowest exposed sandstone whose stratigraphic position is unknown. Farther northwest, near Reese Creek, andesitic grains, pebbles, and cobbles dominate the uppermost part of the formation.

Claystone and mudstone occur throughout except in the Reese Creek exposure at the very top of the formation. Color ranges widely; yellow, green, and olive drab are most common. Brown beds rich in plant debris are common near the base, where a few thin lenticular beds of coal also are present locally, especially on Mount Everts. Red-tinted claystone is present very locally in the exposure west of Eagle Nest Rock, probably very high stratigraphically in the formation and possibly reworked during some ancient period of exposure.

Nearly all fine-grained rocks are bentonitic, and commonly they weather to a "popcorn" structure; some white or light-gray beds. are pure bentonite that swells conspicuously when soaked in water. 
Disseminated biotite flakes are common in the purer bentonite, which is best exposed north of the airstrip about 2 miles northwest of Gardiner. In most areas some claystone is silicified and changed to porcellanite. In wide relatively flat dipping exposures (Landslide Creek area) and in surface debris found on landslides, much claystone has been silicified; but in steeply dipping, rapidly eroding exposures, a high percentage of plastic bentonite remains, which suggests that conversion to porcellanite is at least partly a weathering phenomenon. Heulandite occurs sparsely along joint faces in some claystone and mudstone.

The uppermost beds and the upper contact are exposed only where the Reese Creek partial section was measured, 11/2 miles west of the quadrangle. Here the formation is a mixture of volcanic sandstone and cobble conglomerate. Red heulandite grains are conspicuous. These friable cut-and-fill deposits are overlain with angular discordance by the oldest Tertiary deposit in the area, the Eocene early acid breccia of Hague, Weed, and Iddings (1896), called dacitic breccia in this report. The dacitic breccia can be distinguished by the angular dacitic fragments and by abundant large fragments of Precambrian schist and gneiss, neither of which have been found in the Landslide Creek Formation.

The Landslide Creek Formation is assigned to the Late Cretaceous on the basis of scattered dinosaur bone fragments from exposures northwest of Gardiner and a Cretaceous pollen assemblage collected by J. D. Love from the exposure west of Eagle Nest Rock (J. D. Love, written commun., 1961). Lithologically the formation resembles parts of the Cretaceous Livingston Group 40 miles north of Gandiner (Roberts, 1963) and to a lesser extent parts of the Cretaceous Harebell Formation 100 miles south (Love, 1956, p. 82). An approximate correlation with the upper three formations of the Livingston Group and with the Harebell Formation is suggested.

Calvert $(1912$, p. 411, 412) named the Reese Formation for rocks near Reese Creek that we separate into two units of different age and origin. Impressed by the coarse volcanic components in both units and by the fluvial characteristics in the lower and in a small part of the upper unit, Calvert lumped them together as a new formation. Examination of his field notes shows, however, that he recognized the angular unconformity within the Reese Formation but unaccountably failed to attach any significance to it when he named the formation. Our investigation indicates that Calvert's Reese Formation includes part of the Landslide Creek Formation and part of the dacitic breccia, and the name Reese Formation should be dropped. 
Wilson (1934b) used the name Judith River Formation for beds essentially identical with the Landslide Creek Formation of the mapped area of this report. We reject his nomenclature because the formation in the Gardiner area is not homotaxial with the Judith River, is much thicker, and is lithologically different.

The precise stratigraphic and structural relations between the geographically separated upper and lower parts of the Landslide Creek Formation are unknown. Countless intraformational unconformities exist, and some may be angular, but none can represent a very great time interval because Precambrian pebbles have not been found in the Landslide Creek Formation.

The increase of coarse volcanic components up section and northwestward in the area indicates that coarse detrital components were derived from a rising landmass, which became increasingly volcanic, somewhere northwest of the area. Some volcanic ash probably was deposited directly from the air without benefit of fluvial reworking. The chert and quartzite fraction is nowhere as coarse as cobbles or boulders, but in some places the volcanic fraction is of cobble and boulder size. This size disparity may indicate a largely sedimentary source area, augmented locally and spasmodically by voluminous coarse volcanic rubble directly from volcanoes or indirectly from volcanic mudflows. Coarse volcanic debris must have been introduced into the river system within a few miles of Gardiner.

A major time break and deep erosion between the Cretaceous and Tertiary deposits of this area has occurred, because part of Late Cretaceous, all of Paleocene, and most of early Eocene time are not represented by any known rocks in the Gardiner area. The extent of the unconformity is indicated best in areas north of the Gardiner fault, where all the sedimentary rock, approximately 10,000 feet thick, was stripped prior to deposition of the dacitic breccia.

\section{CENOZOIC ROCKS}

\section{LOWER CENOZOIC VOLCANIC ROCKS}

\section{DACITIC BRECCIA}

In the Gardiner area, most of the Eocene map unit called acid andesitic breccia and flows by Iddings and Weed (1894) is oversaturated with silica and contains abundant quartz crystals in the tuff phases and quartz phenocrysts as well as groundmass quartz in the breccia fragments and in associated lava flows. The name "dacitic breccia" used in this report is an estimate of the dominant composition and texture. A few breccias more alkalic or more mafic than dacite may be present, and rhyodacite may be common in the 
quartz-rich tuff phases. One chemical analysis shows nearly 68 percent silica in a breccia from Sepulcher (Sepulchre) Mountain near the southwest cormer of the area (J. P. Iddings, in Hague and others, 1899, p. 272). Similar rocks have been called early acid breccia in Yellowstone National Park (Hague and others, 1896), but the correlation, as will be shown, is only approximate.

In the mapped area north of the Gardiner fault, nearly all the dacitic breccia was removed before the next formations were deposited. Maximum remaining thickness in that area is about 150 feet. In the mapped area south of the fault, the dacitic breccia, though abundantly represented in landslides, is not in primary form and has not been mapped in this report as an Eocene deposit. Elsewhere on Sepulcher Mountain the dacitic breccia is about 500 feet thick (J. P. Iddings, in Hague and others, 1899, p. 120).

The dacitic breccia is so variable that no single description is suitable for all of it. In order of decreasing abundance, the formation contains tuff breccia, tuff (including bentonite and porcellanite), volcanic sandstone or conglomerate, and lava flows. The lava flows have been found only north of the Gardiner fault. Fossil wood, twigs, and leaves are present locally, especially in tuff near the base.

The most characteristic single feature is the occurrence together of porphyritic dacite and crystalline Precambrian breccia fragments. Neither of these is present in any Cretaceous formation or in the overlying andesitic breccia except, very locally, as inclusions, islands, or boulders of dacitic breccia at the base of the andesitic breccia. Generally the dacitic breccia is light gray, mottled by yellow, red, brown, purple, or green. Bedding is chaotic or poorly defined, except in some tuff-rich zones and sedimentary lenses. The small isolated exposures in the Gardiner area represent only the base of the formation. These exposures are dominantly tuff breccia or coarse lapilli tuff, the coarse fragments of which are less than 2 inches in diameter. Scattered 6-inch-thick blocks and layers of coarser debris are present locally. Volcanic bombs are rare or absent, and few breccia fragments are vesicular. A very thin layer of Precambrian boulders or blocks, which are as much as $1 \frac{1 / 2}{2}$ feet in diameter and which have a sparse tuff matrix, is present very locally as a basal conglomerate. This material is best exposed about 2 miles west of the quadrangle near Reese Creek, on a spur extending north from Sepulcher Mountain.

Common phenocrysts in breccia fragments and lava flows are zoned oligoclase and andesine, biotite, hornblende, and quartz. Altered clinopyroxene and orthopyroxene are less common. The fine- 
grained and altered matrix contains orthoclase, plagioclase, quartz, magnetite, zircon, and apatite.

Separation of dacitic breccia from younger andesitic breccia is difficult in some areas. Precambrian fragments are characteristic of the dacitic breccia. Also characteristic of the dacite breccia are the prevailing light colors, the paucity of plant fossils, the smaller size of breccia fragments, the more coarsely porphyritic nature, the common occurrence of biotite and quartz, and the easier weathering of the breccia fragments. Volcanic breccia fragments in dacitic rocks weather about the same as the matrix. In andesitic breccia the large dark-colored fragments stand out in bold relief from the lighter colored matrix, where present, or exhibit a coarse rubbly appearance in rocks that have little tuff in the interstices.

The origin of volcanic breccia has been discussed at length in the literature (Anderson, 1933; Curtis, 1954; Parsons, 1960) and is not repeated here. Much of the dacitic breccia, including the Precambrian parts, was broken and mixed underground before eruption, for rocks identical in appearance to some extrusive breccia have been found in small shallow plugs, dead-end apophyses, and dikes in and near the mapped area north of the Gardiner fault. (See section on "Intrusive Rocks"). Nevertheless, abundant vitric tuff in the extrusive sequence indicates explosive refragmentation and a liquid magmatic component. After breccia formation and after initial deposition as a primary pyroclastic deposit in Eocene time, some debris was redistributed by mudflows and streams. Quaternary remobilization of the dacitic breccia and adjacent formations by earthflows has also been noted (Waldrop and Hyden, 1963).

\section{Retief}

North of the Gardiner fault in the uplifted Beartooth block, the dacitic breccia was deposited on an extremely irregular surface from which, in the mapped area, all Paleozoic and Mesozoic formations had been stripped and into which deep valleys comparable to those of today had been cut. Local relief was at least 2,400 feet in the mapped area, or 3,600 feet if the area immediately north is considered (Iddings and Weed, 1894). It is unlikely that this rugged topography was smoothed out appreciably by the intermittent and probably localized deposition of dacitic breccia. Probably no single depositional layer, except for easily eroded and rearranged tuff blankets, ever covered the entire area. An ancestral North Fork valley (now exhumed) was as deep as the present one, and nearly all the dacitic breccia was removed from it before the overlying andesitic breccia was deposited. In North Fork valley, boulders of 
dacitic rock have been found in the base of the andesitic breccia where it rests on Precambrian rock near the north edge of the mapped area.

Though the above estimates of local relief on deposition surfaces. may include some undetected postdepositional faulting or warping, the data suggest a mountainous prevolcanism topography that was maintained into andesitic breccia time. The altitude above sea level of the highest peaks was probably less than 5,000 feet (compare Rouse, 1947, p. 168; Dorf, 1960, p. 257).

South of the Gardiner fault, deep erosion before and after deposition is not as apparent. Nevertheless, dacitic breccia does rest on deformed and truncated Cretaceous rocks, and locally there is a coarse basal conglomerate which contains Precambrian blocks or boulders. Intraformational unconformities have a relief of at least 100 feet, and before the andesitic breccia was deposited the dacitic breccia was weathered (J. P. Iddings, in Hague and others, 1899, p. 121). In addition, trachybasalt (described below) was deposited on Cretaceous rock in an ancestral Yellowstone valley that cut through the dacitic breccia just north of Sepulcher Mountain. This Eocene valley is confirmed by the depth of an ancestral North Fork valley in dacitic breccia time and again in andesitic breccia time.

\section{Age, correlation, and source}

None of the plant fossils collected from the Gardiner area are diagnostic of age. The dacitic breccia and partly correlative units of felsic breccia, tuff, or sedimentary rock have been considered Eocene since the last century. Recent work by Dorf $(1960$, p. 258) dated the early acid breccia of north-central Yellowstone National Park as late early Eocene to early middle Eocene. Probably the dacitic breccia of the Gardiner area correlates in part with the early acid breccia.

In a recent study of lower Cenozoic volcanic rocks east and southeast of the Gardiner area, H. J. Prostka (written commun., 1967) mapped a trachyrhyolite welded tuff above a discontinuous deposit of early acid breccia and below a greater thickness of early acid breccia. This confirms observations made previously by J. P. Iddings (in Hague and others, 1899, p. 321-325). But Iddings and Weed (1894) found the trachyrhyolite interbedded with andesitic (early basic) breccia only $2 \frac{1}{2}$ miles northeast of Jardine, and we found the same relation in the Gardiner area. Probably the dacitic breccia of the Gardiner area correlates with only the lower or pretrachyrhyolite part of the early acid breccia of north-central Yellowstone National Park. 
Some dacitic breccia north of the Gardiner fault must have come from volcanoes near intrusive centers that are indicated southwest of Sheep Mountain (pl. 1). Dacitic breccia south of the Gardiner fault came from the north also, as noted by J. P. Iddings (in Hague and others, 1899, p. 121), for it pinches out to the south, contains Precambrian breccia fragments, and does not contain lava flows.

\section{TRACHYANDESITE FLOWS}

The local partly new map unit called trachyandesite flows in this report is a highly variable composite of Eocene rocks which are exposed mostly as isolated patches. The flow remnants range from trachybasalt (lava) through trachyandesite (lava and minor breccia) to trachyrhyolite (welded tuff). Silica ranges from 50 to 70 percent. The chemical common denominator is high total alkali generally with more potash than soda, which is expressed mineralogically as orthoclase in the groundmass of even the most mafic rocks and by absence of quartz phenocrysts in even the most silicic rocks.

In the Gardiner area the trachyandesite flows can be viewed as remnants of a not everywhere mappable basal facies of the andesitic breccia, which rests with erosional unconformity on the dacitic breccia or on older rocks. The trachyandesite flows, each with a different pattern and none covering the entire area, were deposited on a very irregular surface from which all, or nearly all, the dacitic breccia had been removed. High areas nearby, some like Sepulcher Mountain that has a thick residuum of dacitic breccia, apparently were not reached by the flows. Locally, at the north base of Sepulcher Mountain, some light-colored breccia overlies trachybasalt. The breccia is interpreted as a Quaternary landslide from Sepulcher Mountain and not as evidence that the dacitic breccia is younger than the trachybasalt.

All the different rock types are found north of the Gardiner fault, mainly in secs. 6, 7, and 18, T. 9 S., R. 9 E., but south of the fault only trachybasalt is present. In the northern area the trachybasalts are present only as Eocene erosion remnants beneath other parts of the unit. Mafic trachyandesite resting on a thin discontinuous residual deposit of dacitic(?) breccia and fossil wood forms the isolated hill 2 miles north of Casey Lake. Scraps of dacitic breccia are present beneath other parts of the unit near the Jardine road; but, in general, flows in this northern area rest on Precambrian rock and flows south of the fault rest on Cretaceous rock. The composite map unit is present on the topographic nose east of North Fork in the northeast corner of the mapped area. There, where exposures are poor, the flows are interbedded with andesitic breccia 
and mapped as part of it. Seager (1944) described similar rocks in an adjacent area to the east.

The remaining total thickness of the composite trachyandesite unit is probably less than 200 feet in all mapped areas. Where included in the andesitic breccia and protected by it east of North Fork, the unit appears to be much thicker.

Trachybasalt or mafic trachyandesite was probably the first rock type deposited, but it does not underlie all parts of the trachyandesite map unit. Trachybasalt (shoshonite, orthoclase basalt) was discussed at length by J. P. Iddings (in Hague and others, 1899, p. 339$347,275-276$ ), who gave two chemical analyses of the rock from this area. The analyses and one norm (Washington, 1917, p. 471) confirm the unusual composition indicated by the mineralogy. Most trachybasalts are porphyritic. They contain 15-30 percent dark minerals and have been highly altered, probably by prolonged Eocene weathering. They have a characteristic waxy luster, amygdules and veinlets filled with chalcedony and calcite, and green or brown secondary minerals. Altered olivine, clinopyroxene, and opaque oxides are common phenocrysts. In rocks that contain little or no olivine, labradorite is a common phenocryst and orthopyroxene may be present as well. Where not too altered to identify, the groundmass contains plagioclase laths mantled by orthoclase, abundant apatite needles, opaque oxides, and pyroxene. Some groundmass plagioclase is andesine rather than labradorite.

Trachyrhyolite welded tuff is poorly exposed in a few places north of the Gardiner fault. Precise stratigraphic relationships are indeterminate, but the trachyrhyolite appears to be younger than the trachybasalt and older than some trachyandesite flows of intermediate composition. The term "trachyrhyolite" is modified after the trachytic rhyolite of Iddings and Weed (1894) and J. P. Iddings (in Hague and others, 1899 , p. 321-325) to indicate a composition between trachyte and rhyolite. The most conspicuous exposures in the Gardiner area are red, black, or light-yellowish-brown partly devitrified vitrophyre. The rock is characterized by its vitroclastic and collapsed pumicebreccia textures (generally determinable only in thin section), by an absence of quartz phenocrysts, by fresh sanidine and altered plagioclase phenocrysts, and by rare altered biotite and pyroxene phenocrysts. Quartz is present in the groundmass of lithoidal varieties, and, very locally, as xenocrysts. Lithoidal varieties are difficult to distinguish from other light-colored flows in the same map unit. In the Casey Lake area a Pleistocene welded tuff (Yellowstone ,Tuff) is in contact with the trachyrhyolite and with other flows in 
the trachyandesite map unit. The Yellowstone Tuff has abundant quartz phenocrysts and no biotite.

Altered generally light-colored trachyandesites make up the bulk of the map unit north of the Gardiner fault. Locally they pass into flow breccia, and, in the North Fork area, both light and dark pyroclastic breccias of similar composition are included with the andesitic breccia. The lavas are finely and sparsely porphyritic and have a trachytic groundmass. Platy flow structure is present locally. Broken phenocrysts and inclusions of felsitic rock are common. Small altered labradorite or andesine phenocrysts make up 5-25 percent of most rocks. Sanidine is also present in the more felsic varieties. Very small mafic phenocrysts - clinopyroxene, biotite, highly altered orthopyroxene, and hornblende - total 2-15 percent. The cloudy groundmass contains orthoclase, oligoclase, opaque oxides, and, in some rocks, quartz. In a few rocks in which groundmass quartz is abundant the rocks are quartz latite or rhyodacite. The trachyandesites can be distinguished from lava flows associated with the dacitic breccia by the absence of quartz phenocrysts and, generally, by less biotite and smaller phenocrysts.

Iddings and Weed (1894) found patches of trachyrhyolite interbedded with andesitic breccia and flows on the south flank of the Beartooth uplift 21/2-16 miles east of where we found a similar relationship. In the Gardiner area the trachyrhyolite is at or near the base of the andesitic breccia. Throughout the Beartooth area the andesitic breccias are lithologically similar to the early basic breccia found in much of the Yellowstone region. In north-central Yellowstone National Park, many workers have found what probably is the same trachyrhyolite, but in that area it is interbedded with the early acid breccia (J. P. Iddings, in Hague and others, 1899, p. 321-325). If the correlation of the trachyrhyolite, an ash-flow sheet, is correct, it indicates that acid breccia from one source was deposited at the same time as basic breccia was deposited from another. In places the two breccias intertongue (H. J. Prostka, written commun., 1967). As the trachyrhyolite is present in both kinds of breccia, its age must be approximately early middle Eocene (Dorf, 1960, p. 258). By implication, other flows in the trachyandesite unit at Gardiner are essentially the same age. The trachyrhyolite is probably the same as the Lost Creek Trachyte of Howard (1937) and the Lost Creek Tuff of Brown (1961), though Brown's (Pliocene) date is clearly refuted by Iddings and by others who have studied the problem.

The source for trachyandesite lavas north of the Gardiner fault must have been nearby and uphill. Ash Mountain (formerly called Sunset Peak), only 3 miles east of the northeast corner of the mapped. 
area, could have been that source. Though trachybasalt flows in the Yellowstone valley could have come from the northeast too, they may have flowed down an ancient Yellowstone valley from a more distant source east or southeast of Gardiner where similar rocks have been found. The map pattern of the trachyrhyolite suggests a topographically high source east of Gardiner, either in the Beartooth uplift or in north-central Yellowstone National Park.

\section{ANDESITIC BRECCIA}

Though rocks described in the older literature as basic breccia are by far the most voluminous and widespread Eocene deposits in the Yellowstone region, only two small and widely separated patches occur in the Gardiner area. One, in the southwest corner, has been modified by Quaternary landsliding so that its contact with the earlier dacitic breccia is obscured. The other patch, in the northeast corner, is interbedded with and dominated by a basal facies of trachyandesite, so that it too is an atypical sample. In this report we call the map unit andesitic breccia, a term equivalent to basic andesicic breccias and flows (Iddings and Weed, 1894). Lithologically these rocks are similar or identical with the early basic breccia of Yellowstone National Park (Hague and others, 1896), but they are not wholly equivalent in age.

The coarse highly variable fragmental texture, very incomplete crystallization, and changes in composition both local and regional make it extremely difficult to determine an average composition and, hence, a correct name. Because we do not know the average composition but hesitate to use the outmoded term "basic," we call the dark-colored quartz-free breccias andesitic breccia in this report. J. P. Iddings' study of the Electric Peak-Sepulcher Mountain area (in Hague and others, 1899, p. 89-148) suggests, for that area only, that the andesitic breccias range from Daly's (1933) average andesite to more sodic and silicic types approaching rhyodacite in composition. However, in areas further north, the basal lava-rich facies of the andesitic breccia is more potassic and less silicic, as noted in the preceding section. These rocks, and probably most associated breccias within and above them, are potassic trachyandesites which have a wide range in composition. Thus, even in the small Gardiner area, the andesitic breccias probably were derived from two chemically and geographically different sources, each of which changed with time to yield a wide variety of rock types. The lower Cenozoic section in the Yellowstone region is dominated by similarly diverse dark-colored breccias.

The andesitic breccia contains tuff breccia, flow breccia, lapilli tuff, tuff, volcanic conglomerate, volcanic sandstone, and unbrecciated 
lava flows. The dominant textural type is tuff breccia coarser than the dacitic breccia. Where tuff is abundant, as in some parts of Sepulcher Moutain, the layering may be well defined; but tuff layers more than 6 feet thick are rare in the Gardiner area, and most of the formation is crudely bedded or unbedded. Near the base, inclusions or boulders of dacitic rocks may be mixed with andesitic breccia.

Blocks 1 foot in diameter are common in the tuff breccia, and much larger ones are present locally; the average diameter is about 4 inches. Characteristically, the dark-gray or dark-brown blocks weather in bold relief over a lighter gray tuffaceous matrix that makes up about 30 percent of the rock. However, the tuff component ranges from slight to dominant. Most blocks have an extremely fine texture with few or no visible phenocrysts. Some are vesicular or scoriaceous; others are flintlike. Bombs also are present in some rocks.

The dominant mode of deposition was probably cold volcanic mudflows-cold because abundant fossil wood is not charred, mudflows because of crude or absent bedding and the heterolithologic nature of some parts (Parsons, 1960, p. 143). Initial deposition may well have been directly from the air, at least for the tuff components, but shortly thereafter mudflows probably rearranged the deposit. That mobility can be regained under special circumstances long after deposition is amply demonstrated by Quaternary earthflows around the northeast base of Sepulcher Mountain.

Petrographic examination of lithic fragments from the Sepulcher Mountain area shows that microphenocrysts are mostly zoned labradorite laths and glomerocrysts or scattered crystals of pyroxene, both arranged in a fluidal pattern. The cloudy microcrystalline or devitrified base contains about 5 percent opaque oxides. In some blocks plagioclase has a seriate development and makes up 60 percent of the rock, but most examined rocks contain less than 30 percent microphenocrysts of any kind. Clinopyroxene generally exceeds orthopyroxene, and together they make up 5-10 percent of most rocks. Basaltic hornblende that has opacite rims is a rare constituent of many rocks but is abundant or dominant locally, as at the top of Sepulcher Mountain (J. P. Iddings in Hague and others, 1899, p. 123). Iddings also found olivine and biotite as very rare constituents. The tuff matrix contains broken fragments of the same crystals found in the large lithic fragments and small globules or irregular patches of brown glass rimmed with chloritic alteration minerals.

Breccia in the northeast corner of the mapped area is different. In places it resembles the dacitic breccia but can be distinguished from it by the absence of quartz phenocrysts, fewer and smaller 
phenocrysts, and less biotite and hornblende. These breccias and associated lava flows are mostly trachyandesite.

Many of the stratigraphic relations, including the erosional unconformity at the base, have been discussed in preceding sections. About 3,000 feet of andesitic breccia caps Sepulcher Mountain southwest of the southwest corner of the mapped area (J. P. Iddings, in Hague and others, 1899, p. 122). Within the mapped area, on the shoulder of Sepulcher Mountain, the contact with the underlying dacitic breccia is obscured by Quaternary landslides so that we were unable to map it. We have mapped most of the southwest corner as Quaternary deposits, but it should be emphasized that about 1,200 feet of andesitic breccia above the 6,800-foot contour has been disturbed mainly by large-scale block glides that left the primary structures intact. Below that level, stratigraphic anomalies and rather complete mixing of the breccias occur.

Stratigraphic thickness in the northeast corner of the area is indeterminate, for one cannot tell how much of the very irregular deposition surface was completely filled and leveled and how much was only mantled or veneered by the breccia. Because the deposition of mudflows and lava is controlled by topography, thickness in North Fork valley must have been greater than on adjacent ridges. Most of the deposit, which may have been more than 3,000 feet thick in the valley, has been eroded away, and nowhere in the area does a younger volcanic deposit overlie it. About 1,000 feet of andesitic breccia and trachyandesite flows remains on the ridge east of North Fork where the prevolcanic base is 2,000 feet higher than it is in the valley. To the west in the saddle south of Five Lakes, residual fossil wood, presumably from andesitic breccia, is more than 2,200 feet above North Fork. Andesitic breccia extends more than 20 miles northeast of the mapped area, capping most of the highest peaks and lining most of the deepest valleys in a rugged mountain terrain (Iddings and Weed, 1894). The breccia must be more than 2,000 feet thick in a large part of that region.

None of the fossil wood collected during this study was diagnostic of age. The partly equivalent early basic breccia in nearby parts of the Yellowstone region is early middle Eocene (Dorf, 1960, p. 259).

There were many different sources for the voluminous and widespread andesitic breccias in the Yellowstone region, but none were found in the mapped area. The southward slope of the deposition surface north of the Gardiner fault, the great volume of andesitic breccia north and east of the mapped area, and the existence of the Gardiner fault, which probably acted as a barrier to northward flow of mudflows or lava, suggest that deposits in the northern part of 
the area came from sources north and northeast of the Gardiner area. The dissected volcanic center at Electric Peak was the source for deposits at Sepulcher Mountain (J. P. Iddings, in Hague and others, 1899, p. 141). Probably the two batches differ in age as well as in composition.

\section{INTRUSIVE ROCKS}

In this area all Cenozoic intrusive rocks are dacitic or andesitic, which suggests that they were emplaced in Eocene time when extrusive rocks of similar composition were being deposited throughout the region. Late Cenozoic volcanism, characterized by rhyolite and basalt, is not represented in the intrusives of the Gardiner area.

Intrusives north of the Gardiner fault and in or close to the fault zone seem closely related to the extrusive dacitic breccia, which they resemble in many details. Intrusives at Sepulcher Mountain and Mount Everts are probably more closely related to andesitic breccia erupted in great volume from the Electric Peak volcano southwest of the mapped area or to late derivatives of that andesitic magma.

DACTTIC INTRUSIVES NORTH OF THE GARDINER FAULT

The porphyritic dacitic rocks that form small plugs, apophyses, and dikes southwest of Sheep Mountain resemble the extrusive dacitic breccia so closely that there can be little doubt of the genetic and temporal association. The intrusives are believed to be the roots of dacitic volcanoes whose surface structure has been entirely removed. All are porphyritic and petrographically similar to abundant blocks and lapilli found in the extrusive dacitic breccia. Biotite and hornblende are the common mafic phenocrysts; plagioclase and, to a lesser extent, quartz are the felsic phenocrysts. The groundmass contains plagioclase, orthoclase, and quartz. Some rocks may be rhyodacite instead of dacite. All or part of some intrusive bodies is brecciated; the breccia contains abundant angular chunks of Precambrian schist and gneiss exactly like that in the extrusive dacitic breccia.

Breccia rich in Precambrian fragments is present in thin dead-end apophyses and dikes in the Precambrian wallrock, which suggests that the breccia formed underground and is not a vent agglomerate. Breccia formation seems to require shallow emplacement, freezing of magma, and renewed intrusion to break the solidified dacite and the wallrock to which it was bonded. Addition of still-liquid magma from below and explosion at some higher level are hypothesized to explain vitric tuff in the extrusive dacitic breccia.

INTRUSIVES IN OR NEAR THE GARDINER FAULT

In several places northwest of the mapped area, small dikes and sills of rock similar to the dacite described above, including some 
intrusive breccia, are intruded in or close to the Gardiner fault. At least two generations of intrusions are indicated at the east base of Cinnabar Mountain (fig. 1), southwest of Corwin Springs, and in a few places the intrusive rocks are sheared, indicating that the Gardiner fault was active, at least in a small way, during or after intrusion. An unbrecciated dacitic dike is present between Bear Creek and Deckard Flats near the center of sec. 19, T. 9 S., R. 9 E., close to the Gardiner fault.

The small size of the intrusives indicates that the Gardiner fault was not a major conduit in the Gardiner area. Moreover, the altitude of extrusive dacitic breccia close to the Gardiner fault shows that in Eocene time the fault area was too low to have supplied lava flows to the much higher areas farther north. Apparently dacitic magmas were available throughout a large part of the uplifted and fractured Beartooth block (Iddings and Weed, 1894).

DAOITE SILL SOUTH OF THE GARDINER FAULT

Probably there was little underground communication for magmas across the Gardiner fault. Southwest of the fault zone, intrusive rocks in the downthrown block probably had sources within that block. Part of a large porphyritic dacite sill is exposed at the north base of Sepulcher Mountain in the southwest corner of the mapped area. In places baked remnants of the Landslide Creek Formation adhere to the upper surface, but generally the overburden has been stripped by glacial erosion and landsliding. Part of the exposed slope appears to be nearly the upper surface of the sill.

The light-gray finely porphyritic rock contains zoned calcic oligoclase and hornblende phenocrysts which have maximum diameters of about $5 \mathrm{~mm}$, smaller and less common biotite and quartz phenocrysts, and a groundmass rich in oligoclase and quartz-orthoclase intergrowths. The rock contains 65.5 percent silica and more than 8 percent total alkali. Soda exceeds potash ( J. P. Iddings, in Hague and others, 1899 , analysis 494, p. 135).

The dacite and some other intrusives near Sepulcher Mountain were called hornblende-mica andesite by Iddings, but probably only a few are andesite by current definition. Many other intrusives, presumably more siliceous ones, were called dacite, and these are especially common just east of a fault in Reese Creek valley that separates Sepulcher Mountain and Electric Peak (Hague and others, 1899, pl. XVI and analyses 521 and 523, p. 135). Probably all these rocks are younger than the extrusive andesitic breccia that many of them intrude. 
Though andesitic breccia was deposited in quantity both north and south of the Gardiner fault, only one andesite intrusive was found in the mapped area. This is a sill as much as 60 feet thick that was intruded near the base of the Everts Formation on Mount Everts. The sill pinches out and is partly covered to the north. This rock is porphyritic hornblende-pyroxene andesite which has hornblende phenocrysts as long as $1.3 \mathrm{~cm}$; other sills in the same mountain are pyroxene andesite (J. P. Iddings, in Hague and others, 1899, p. 85). The andesite could have been intruded at any time from the late Cretaceous to the Oligocene, but probably it was intruded during a middle Eocene episode of andesitic volcanism at Electric Peak.

\section{UPPER CENOZOIC VOLCANIC ROCKS}

No deposits of late Eocene, Oligocene, or Miocene age are known in the area, though some may exist beneath thick cover in the Yellowstone valley and others may have been eroded away. Volcanism during the hiatus probably did not stop entirely. Magma from dacitic intrusives that cut andesitic breccia south and north of the mapped area (Iddings and Weed, 1894; Hague and others, 1896; Hague, 1904) may have furnished tuff a little younger than the andesitic breccia. Elsewhere in the region, early Tertiary volcanism continued longer than is indicated in the Gardiner area (Hague and others, 1896; 1899). Oligocene volcanic rocks are known in the Madison Range to the west (Hamilton and Leopold, 1963); upper Miocene and lower Pliocene tuffs occur in the Yellowstone valley 20 miles north of Gardiner (Horberg, 1940) ; Eocene, Oligocene, Miocene, and Pliocene tuffaceous deposits are known in Jackson Hole to the south (Love, 1956, p. 86-93) and in many intermontane basins throughout southwestern Montana.

BASALT

Pliocene(?) basalt discontinuously mantles the bench northeast of the Yellowstone River for $61 / 2$ miles from Little Trail Creek to Deckard Flats. Much of the once-continuous and much more extensive deposit, all confined to an ancient Yellowstone valley, is covered or eroded away, but nearly complete exposures at either end of the bench contain five separate flows. One or two lower flows commonly fill channels, are discontinuous, and have irregular or fanlike columnar joints (fig. 2). Except where subsequently deformed, the three upper flows generally have flat tops, vertical joints, and poorly defined horizontal flow planes.

In an up-faulted block northwest of Little Trail Creek at the west edge of the mapped area (fig. 4), individual flows thin and abut the 


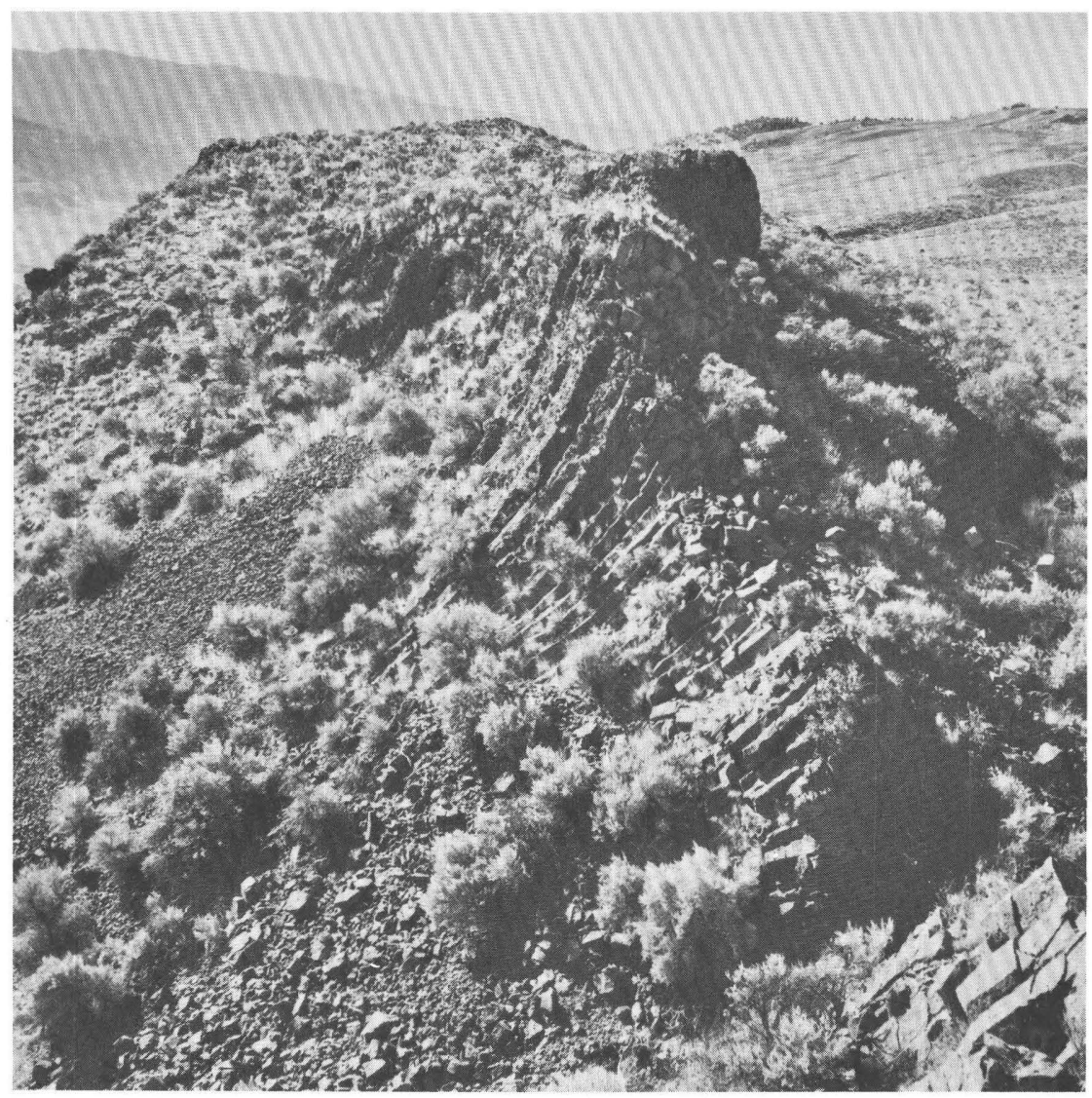

FIgURe 2.-View looking northwest at irregular channel-filling basalt flow. Columns are perpendicular to flow planes. Left of hill (near center of sec. 24, T. 9 S., R. 8 E.), flow planes dip left toward the Yellowstone River; across Jardine road to right of picture, basalt emerges from covered channel to form flat flow. Most remaining basalt behind camera is also flat lying.

north side of the old valley wall and are overlapped successively by younger flows that feather out at higher levels. This arrangement, also suggested at the northeast edge of exposures elsewhere along the bench, shows that the basalt ponded in the valley and did not flow downslope from the north. Other aspects of the distribution pattern indicate that the basalt flowed into the mapped area from upstream along the Yellowstone River.

In the deepest part of the old valley, the composite thickness of flows may have been more than 400 feet, and probably more than five flows were represented. The somewhat tapered remnant has a maximum composite thickness of about 300 feet. Individual flows are 40-60 feet 
thick where they can be examined in cross section. In places only one flow or part of one flow remains.

The basalt is essentially unaltered except in hot-spring areas. The fresh character, the areal distribution, and the rarity of mafic phenocrysts in the basalt distinguish it from previously described trachybasalt. A principal characteristic of the young basalt is the general lack of pyroxene phenocrysts and the rarity of olivine phenocrysts. The basalts are dark gray; they generally contain less than 5 percent vesicles, though more vesicular zones, even clinkery and scoriaceous zones, are present at top and base of some flows. Quartz xenocrysts and inclusions of Precambrian rock are rare and small. Textures range from ophitic and intergranular to hyalo-ophitic, containing as much as 30 percent impure and nearly opaque glass. Sparsely porphyritic varieties are common, but rarely do phenocrysts exceed 10 percent of the rock, and nearly all the phenocrysts are labradorite. The maximum observed size of labradorite crystals is $15 \mathrm{~mm}$, but most of the crystals are much smaller.

The same mineral species occur in all examined rocks, but their proportions range widely : labradorite, 40-50 percent; clinopyroxene, 10-35; olivine, 3-15; opaque oxides, 3-7; apatite, a trace. In wellcrystallized rocks the partly ophitic clinopyroxene is the dominant mafic mineral, olivine occurs as clear grains, opaque oxides occur as relatively large discrete grains, and the glass (about 10 percent of the rock) is brown and transparent, charged mainly with apatite needles. In some rocks that contain about 30 percent impure glass, the clinopyroxene is confined mainly to the glass as poorly defined cloudy crystals, the opaque oxide also is concentrated in the glass, and the olivine, interstitial to labradorite and altered incipiently to yellow "iddingsite," is the conspicuous mafic mineral. Olivine in these rocks has separated in excess of its stoichiometric proportion. Probably most young basalts are approximately saturated, containing considerably less than 5 percent normative olivine or quartz (Boyd, 1961, p. 401, table 3). The rocks are chemically and petrographically distinct from the older trachybasalts of the region.

Intracanyon basalts both older and younger than the Pleistocene Yellowstone Tuff have been found upstream along the Yellowstone River and in other parts of Yellowstone National Park (J. P. Iddings, in Hague and others, 1899, p. 433; Boyd, 1961, p. 402), but in the Gardiner area the basalt does not contact the Yellowstone Tuff. Locally at Deckard Flats the basalt is underlain by a thin and discontinuous stream deposit of conglomerate and siltstone, which Seager (1944, p. 35) believed to be Pleistocene. Alden (1932), Wilson (1934a), and Horberg (1940) also believed that the basalt was 
Pleistocene. However, the deposit beneath the basalt contains no recognizable Yellowstone Tuff, and the geomorphic arguments advanced to indicate a Pleistocene age are inconclusive. Thus, the basalt can not be dated more accurately than late Tertiary or Pleistocene from purely geologic evidence in the Gardiner area.

Though the present downstream limit of the basalt is approximately the west edge of the mapped area, the flows did not stop there. Probably correlatives were mapped 16 miles downstream from Gardiner (Iddings and Weed, 1894) on a bench above the Yellowstone River. The upper of two basalt flows in the downstream area has a reported potassium-argon age of 8.4 million years (Bush, 1967). Therefore, we have assigned a Pliocene(?) age to the basalt at Gardiner.

We found no vents or feeder dikes in the Gardiner area and presume, therefore, that the basalt flowed into the area from upstream along the Yellowstone River. This route rather than the Gardner River valley is indicated because the large deposit at Deckard Flats could not have been fed from the Gardner valley without a stream reversal. Also, there are no residual patches of basalt nearby in the Gardner valley, where glacial and postglacial erosion was presumably less intense. Though correlatives of the basalt at Gardiner undoubtedly are present along the Yellowstone drainage not far upstream from Deckard Flats, we have not studied that area and cannot tell which of the many flows are the correlative ones.

Wilson (1934a, p. 663, fig. 6) suggested that the basalt was derived from a dike that intruded the thrust plane of the Gardiner fault and then emerged as a flow. The outcrop seen by Wilson is the hill 2,200 feet southwest of Blanding Station, just south of the Jardine road in sec. 24 , T. 9 S., R. 8 E. (fig. 2 ; pl. 1). We believe that the entire outcrop is extrusive and unrelated to the Gardiner fault.

The dikelike structure seen by Wilson is similar to others found in the first one or two channel-filling flows. Irregularities in the basal flows, commonly indicated by flaring or curving columnar joints, result from deposition on an uneven surface. Erosion of superjacent flows and exposure of only one side of a basalt-lined channel give the impression of an inclined dike passing upward into a nearly flat flow. Most basalt in the area noted by Wilson is essentially flat, but parts of the tabular layer dip southwest toward the river, and other parts dip northeast (fig. $2 ;$ pl. 1). The controlling layer of basalt appears to have been twisted like a ribbon, and the columnar joints are roughly perpendicular to the plane of the ribbon. Probably the axis of one channel that caused this irregularity is covered by glacial till and lies close to the Jardine road; north of the road the basalt is 
again flat, which indicates that it overflowed the channel. The southwesterly dip in the basalt on the southwest corner of the main outcrop may reflect a subparallel channel or the main bank of the ancestral Yellowstone River.

Less spectacular irregularities of the same kind occur elsewhere. One located 2,100 feet southeast of the previous outcrop is roughly anticlinal. Others occur near the old travertine quarries north of Gardiner, where one distorted basalt flow was quarried for riprap. At the base of the cliff at Deckard Flats, a U-shaped basalt-lined channel about 15 feet deep is exposed in cross section. Exceptional irregularities in basalt deposition of the same kinds as those described here have been described and photographed in the Snake River area (Waldron and Gard, 1951, p. 15-18, 50).

Along the front of the basalt bench near Gardiner, slabs of basalt flows were detached and steeply tilted in Holocene time. Some slabs have a dikelike form and one was photographed and interpreted as a dike by Howard (1937, pl. 7, fig. 2, p. 66). The block-faulted and superficially disrupted bench is discussed further in the section "Structure."

\section{YELLOWSTONE TUFF}

Boyd (1961) named, described, and mapped the Yellowstone Tuff over a large part of the Yellowstone region and distinguished it from the upper Cenozoic rhyolites that had been mapped with it previously (Hague and others, 1896). The other rhyolites, none of which occur in the Gardiner area, are mostly younger lava flows restricted to the central area of the Park. The Yellowstone Tuff, however, is an ash-flow sheet that moved into outlying valleys. New evidence indicates that the Yellowstone Tuff is Pleistocene. Erosional remnants, which crop out in the Gardiner area 6-71/2 miles north of the northernmost exposure mapped on Mount Everts by Boyd, were mapped as rhyolite by Iddings and Weed (1894) and Seager (1944). The original deposit probably extended farther up North Fork and Bear Creek. Most remnants are densely welded tuff, but the featheredge and the upper part, where present, are only partly welded to nonwelded and are indurated mostly by crystallization.

The original deposit in the park averaged about 500 feet thick and locally was as thick as 1,000 feet (Boyd, 1961, p. 393). Remnants that cap the irregular surface and fill ancient stream valleys in the Gardiner area probably have a maximum vertical thickness of about 200 feet. However, maximum stratigraphic thickness may have been much greater, because ash-flow deposits generally have flat tops (Ross and Smith, 1961, p. 23), and in this area the local relief from 
base to top of a single remnant exceeds 1,100 feet (pl. 1, secs. 5, 8, 17, T. 9 S., R. 9 E.).

The Yellowstone Tuff is rhyolite that contains about 75 percent silica, more than 30 percent normative quartz, and quartz phenocrysts (Boyd, 1961, p. 398, 408, 409). It is considerably more silicic than the older trachyrhyolite, which has few, if any, quartz phenocrysts.

Though composition probably remains essentially the same throughout the deposit, texture varies depending on stratigraphic and geographic position. Three principal textural zones and transitions between them have been observed in the Gardiner area (terminology after Smith, 1960): a basal, vitrophyric zone; a eutaxitic, medial devitrified zone; and an upper, vapor-phase zone. The rocks in all three zones are composed dominantly of shards and subordinately of pumice and contain similar phenocrysts, but the degree of welding and the type and the degree of crystallization are variable. The only conspicuous differences between the Gardiner remnants and those described by Boyd are the general absence of a basal air-fall ash and the presence, very locally, of a vapor-phase zone without vitrophyric or devitrified zones. The air-fall ash presumably was present in the area, however, because a small patch was found on the east side of Hanlon Hill.

In the Gardiner area the basal, black vitrophyre is present whereever the deposit is thick enough to have a devitrified zone as well. The vitrophyre is well exposed at a small quarry in the tuff along the Jardine road in $\mathrm{SW} 1 / 4$, sec. 8 , T. 9 S., R. 9 E. At that locality it is 1-5 feet thick and lines an ancient south-trending channel tributary to ancestral Bear Creek. Much of the vitrophyre is perlitic, and locally it is brecciated. The numerous sanidine, quartz, and sodic plagioclase phenocrysts are conspicuous in hand specimen, but deformed and welded shards molded around the phenocrysts and small collapsed streaked-out pumice fragments generally are visible only under the microscope. Mafic phenocrysts make up less than 1 percent of the rock: green slightly pleochroic ferroaugite is most abundant, magnetite is common, and yellow fayalite is rare. Many crystals are broken; others, particularly the plagioclase, are embayed.

The vitrophyre grades upward within about 6 inches into a massive purplish-gray lithoidal porphyritic layer about 5 feet thick, which commonly is overlain by a zone of coarse lithophysae. The tuff then passes into the dominant devitrified zone which is about 200 feet thick northwest of the quarry. The devitrified zone is generally platy and easily weathered to a fine gravellike colluvium. It is medium light gray, contains discontinuous very light gray streaks of flattened devitrified pumice, and weathers brown or purple. Devitri- 
fication has partially obscured the welded vitroclastic texture in most rocks and has obliterated it in a few. Axiolitic patterns can be recognized in some shards. The rock contains the same phenocrysts as the vitrophyre, but the sanidine is mottled and partly unmixed to cryptoperthite (Boyd, 1961, p. 399). Most pumice and some shards are coarsely devitrified to dominant tridymite and subordinate alkali feldspar.

The vapor-phase zone is present in only a few places. It is white, light gray, or pink, lightweight, soft, and rich in uncollapsed devitrified pumice set in a dominant matrix of undeformed and generally axiolitic shards. Some exposures are so soft that a geology pick can be driven about 1 inch into them without breaking the rock. The best exposures occur on the sides of two gullys about half a mile southeast of Casey Lake. On the east side of the southern gully, the upper zone, about 100 feet thick, appears to grade downward through a vesicular zone to the devitrified zone. On the north side of the northern gully, a thin layer of the vapor-phase zone rests directly on older rock with no intervening lithoidal or vitrophyric tuff but is identical with the upper vapor-phase zone elsewhere. South of Pole Creek an abundantly vesicular zone may be transitional upward or laterally to the vapor-phase zone and downward to the devitrified zone. Phenocrysts in the vapor-phase zone are similar to those in the main part of the deposit, but rare small scraps of reddish-brown biotite were noted in a single thin section. The biotite, like abundant alien inclusions of subjacent trachyandesite, may have been picked up from the surface over which the tuff flowed. Tridymite and alkali feldspar are common as cavity linings and replacements of pumice and shards.

Alien inclusions were found in all three zones from bottom to top of the deposit. Where the formation rests on Precambrian rock, the inclusions, which are as large as 2 inches across near the base and half an inch across near the top, are mostly Precambrian. Where the formation rests on trachyandesite, the inclusions, locally as large as 6 inches, are mostly of that rock. This distribution of alien inclusions points strongly to a surface origin, as does the presence locally of included material that appears to be baked clay or soil. The general absence of the basal air-fall ash also suggests that the ash flow picked up loose surface debris.

The stratigraphic thickness (possibly more than $1,000 \mathrm{ft}$ in the Bear Creek area), the similarity of the densely welded vitrophyric and devitrified zones to those described by Boyd that are 7 miles closer to the source, and the surface-derived inclusions throughout the deposit suggest that the bulk of the formation was emplaced as 
a vigorous and turbulent gas-charged avalanche that apparently was thickened and impacted as it flowed upstream. The west edge of the north-trending salient flowed up tributary gullys and thinned abruptly. Probably the frothy featheredge, which may have been deposited at a different time, extended only half a mile west of Casey Lake. The entire deposit has been removed from the east side of Bear Creek valley, and any lobes that flowed up or down the ancestral Yellowstone River valley also have been eroded away.

Formerly the Yellowstone Tuff was correlated with the Pliocene Teewinot Formation of Jackson Hole (Boyd, 1961, p. 410; Love, 1961, p. 1754). Now it appears that only certain older welded tuffs south of Yellowstone National Park intertongue with the Teewinot (J. D. Love, written commun., 1966).

A new study in Yellowstone National Park by R. L. Christiansen and H. R. Blank indicates two major cooling units in the Yellowstone Tuff separated by an erosional unconformity; paleomagnetic polarities and preliminary potassium-argon dates indicate a Pleistocene age (Christiansen and Blank, oral commun., 1967). The bulk of the deposit in the Gardiner area is identical with the lower unit, which was described at Mount Everts by Boyd (1961).

\section{SURFICLAL DEPOSITS}

CONGLOMERATE BENEATH BASALT

Discontinuous stream-deposited conglomerate of Pliocene(?) age underlies the basalt at Deckard Flats. In most exposures the deposit is less than 10 feet thick. Seager (1944, p. 36) reported that the deposit had been worked for gold by underground as well as surface methods and that in places it may be more than 25 feet thick. Less well defined deposits, partly or entirely colluvial, are present elsewhere, especially beneath the perched basalts northwest of Little Trail Creek at the west edge of the area. These contain fragments of Precambrian rock and dacitic breccia. The deposits are very thin and discontinuous and have not been mapped.

The deposits at Deckard Flats include coarse poorly cemented gravel that contains rounded boulders as much as 3 feet in diameter, finer conglomerate, sandstone, and siltstone. This ancient alluvium, derived from the Bear Creek drainage and deposited near the ancestral mouth of that stream, contains boulders and cobbles of crystalline Precambrian rock and a great variety of lower Tertiary volcanic rocks. The volcanic-rock cobbles are mostly porphyritic quartz-free varieties that contain labradorite and two pyroxenes; tuffaceous rocks are common. The volcanic material was probably derived from the trachyandesite flows and the andesitic breccia. 


\section{CONGLOMERATE YOUNGER THAN BASALT}

In a few places Pleistocene conglomerate or breccia that is younger than the basalt and older than most of the travertine is located beneath or close to travertine. This material includes thin and discontinuous colluvial, fluvial, and glacial deposits differentially cemented by clay or calcium carbonate and locally altered by hot-springs solutions. In places, the deposit is nearly pure basalt talus; elsewhere, Precambrian or Tertiary debris is abundant. Only a few deposits are thick enough to map. Most if not all of the deposits are remnants of postbasalt glacial and interglacial deposits that were protected from subsequent glacial and fluvial erosion by the travertine. Some may be very late Pleistocene in age, and some probably are pre-Wisconsin.

\section{TRA VERTINE}

Many areas in the vicinity of the Gardiner fault are veneered by an irregular hot-spring deposit of travertine. This material ranges in age from Pleistocene to the present. Just west of the mouth of Bear Creek and also west of the mapped area, a small amount is still being deposited by feeble hot springs, but a large part was deposited before glaciation of Wisconsin age which scraped away some travertine and left a veneer of boulders on the remainder. Glacial boulders altered by hot springs have been found beneath and within travertine, but most of them are on top and unaltered. Locally the travertine itself occurs as glacial boulders.

The travertine ranges in thickness from a thin film to 40 feet. In many places it is at least 15 feet thick. Probably the original deposit was about 4 miles long and half a mile wide-comparable to the one at Mammoth in Yellowstone National Park. Presumably the deposit at Gardiner formed on a different fault but in the same way (Allen and Day, 1935, p. $33,88,360)$ : hot juvenile solutions initially rich in carbon dioxide and water rose along the Gardiner fault, mingled with and heated the ground water in the fracture zone, dissolved Paleozoic and Mesozoic limestone present in the fault zone, and then precipitated calcium carbonate at the surface.

The travertine has been quarried for many years and was still being quarried in 1964. Most of it is used as a decorative facing for buildings, among which is the Gardiner Post Office. The stone has a mottled white, gray, pink, and brown color and an irregular laminar and porous structure that has a pleasing appearance as rough, sawed, or polished building stone. Small specimens are popular items in the local rock shops.

GLACIAL DEPOSIIS

Glacial deposits of at least three different ages are in the Gardiner area. Apparently each subsequent glaciation was smaller than the 
preceding one and more nearly confined to valleys, but all glaciers in the Yellowstone valley were unusually large (Weed, 1893; Howard, 1937 ; Horberg, 1940; Love, 1961). Precise criteria for separation of the different deposits were not found in the Gardiner area, and the discussion must be considered tentative. Except for Pinedale moraine in and near the town of Gardiner, deposits of different ages and origins, including till and glaciofluvial material, have not been separated on the map. The deposits that are obviously fluvial and probably of Pinedale or younger age have been mapped as alluvium.

The oldest known glacial deposits are erratics on the high ridges. On the ridge northeast of Niggerhead Peak, such deposits extend to 9,000 feet. An ice cap that filled all valleys that existed at that time and left only the highest peaks and ridges exposed is suggested. Similar deposits and other evidence for early high-level glaciation have been found elsewhere in the region (Hall, 1959; Love, 1961; Montagne, 1964; Richmond, 1964). Generally such evidence is assigned to pre-Bull Lake glaciations of unknown number and age. The highest erratics are 1,000 feet or more above integrated deposits of till, and none have been mapped in this report.

\section{UNDIFFERENTIATED DEPOSITS}

The oldest mapped glacial deposits, which discontinuously mantle many surfaces below 7,800 feet and probably include both Bull Lake and Pinedale deposits, are thin and variable and do not form welldefined moraines in this area. They have been mapped only where bedrock geology is completely masked. Erratics extend to even higher altitudes, so that the dimensions of the ice lobe suggested below are minimal. The irregular and patchy but very widespread distribution of till suggests ground moraine deposited by lobes of ice too large for the valleys. Deposits of this type mantle parts of Mount Everts as high as 2,000 feet above the present Yellowstone River, occur sparingly on the northeast slope of Sepulcher Mountain 1,600 feet above the river, extend northward from the basalt bench above Gardiner to the vicinity of Parker Point 2,600 feet above the river, and occur in the northwest corner of the area 2,300 feet above the river. In many places the upper edge merges with thick colluvium. The lower edge along the basalt bench is slumping in many places and there too becomes colluvium. Locally the deposits are crudely bedded and contain some glaciofluvial material. Generally the lower edge is less than 1,000 feet vertically above the Yellowstone River and is coarse, fresh, and knobby; these characteristics suggest a Pinedale age.

Ice-marginal channels above the basalt bench in the Phelps Creek and Eagle Creek areas and nearly as far north as Casey Lake indi- 
cate, along with the distribution of till, that the ice lobe at one time was at least 5 miles wide through Gardiner. The ice must also have been very thick-perhaps 2,500-3,000 feet. Downstream from Gardiner about 15 miles, the ice was at least 3,000 feet thick according to Horberg $(1940$, p. 296). Some idea of the size and thickness of the lobe can be gained from the grooved topography, the undrained depressions, and the drift high on the northeast slope of Mount Everts. (See U.S. Geol. Survey Mammoth, Wyo.-Mont., topographic quadrangle map.) The ice must have passed over this mountain.

Remnants of a silt deposit are found 1-2 miles upstream from the mouth of Bear Creek on either side of that stream. Seager (1944, p. 37) suggested that this material was deposited in a lake dammed by basalt at Deckard Flats. This seems unlikely because the silt, some of which is varved, extends to altitudes above the basalt and is capped by terrace gravels also higher than the basalt. All this material is mapped collectively as part of the undifferentiated glacial unit. Glacial scouring and flushing should have removed any unconsolidated deposit impounded by basalt. It is possible, therefore, that the silt was deposited in a late Pleistocene lake impounded by ice or moraine (later flushed away) near the mouth of Bear Creek when the Bear Creek glacier no longer joined the Yellowstone glacier.

As noted above, we were unable to separate discrete ages of glaciation in most areas. Probably Pinedale ice occupied much of the same area previously occupied by Bull Lake ice. Poorly defined deposits at higher levels may represent Bull Lake till modified in Pinedale time by glacial or periglacial activity.

PINHALIE DEPOSITS

Parts of a young moraine are exposed near the schoolhouse in the town of Gardiner at an altitude of about 5,280 feet, well below previously discussed deposits. Other exposures are north of the Yellowstone River and upstream from the town, where they overlap the basalt bench and probably merge with older Pinedale and Bull Lake deposits (pl. 1). Surely the lowest material is Pinedale, but whether the moraine at Gardiner represents the Pinedale terminus or is merely recessional is unknown.

Horberg $(1940$, p. 281,301$)$ found what he believed was the Pinedale terminal moraine about 30 miles downstream from Gardiner, less than 5 miles upstream from the Bull Lake terminus. This would require an early Pinedale lobe thick enough to overlap the basalt bench even downstream from Gardiner. Till and erratics, probably of Pinedale age, are present on the basalt bench as far as 3 miles downstream from the Pinedale moraine at Gardiner. Horberg's interpre- 
tation, which implies that the Pinedale moraine at Gardiner is recessional, is the probable one on the basis of published data.

Other patches of till exist, mostly in areas well above and remote from the Yellowstone River. Probably most of these result from glaciation localized in relatively late Pinedale time.

\section{LANDSLIDES}

Conspicuous landslides, mostly but not entirely of Holocene age and partly still active, started from the Sepulcher Mountain area and moved downhill toward the Yellowstone and Gardner Rivers. The landslides have been described by Waldrop and Hyden (1963). Supplementary data are offered here in explanation of the slightly modified map units (fig. 2) and the ambiguous bedrock-surficial relationships.

All gradations occur, from lobate and elongate earthflows, which extend all the way to the rivers, to large jostled blocks confined mostly to Sepulcher Mountain and delineated by locally mappable fissures and faults. The downhill ends of the earthflows are mappable Quaternary units which have a discernible chronology (Waldrop and Hyden, 1963) that is shown on plate 1; but the uphill part is mappable andesitic breccia-lower Tertiary bedrock-only slightly disturbed by Quaternary landsliding. Between these extremes is a poorly defined area, composed mostly of slump and glide blocks, where neither the bedrock nor the surficial contacts can be delineated consistently. The poorly defined area is given a special Quaternary map symbol, and its contacts are arbitrary (pl. 1).

Before sliding, the poorly defined area contained mostly dacitic breccia, which is still the dominant rock type in many areas; but as this material oozed out, its upper contact with the andesitic breccia and its lower contact with the Cretaceous Landslide Creek Formation were modified or destroyed. Plastic bentonite, abundant in the dacitic breccia and the Landslide Creek Formation, lubricated the landslides.

The distal end of the westernmost earthflow mapped by Waldrop and Hyden (1963, fig. 182.1) is exclusively dacitic breccia, much of it a firm lithified rock that looks exactly like the original Tertiary deposit in hand specimen and in outcrop. That it is not a Tertiary deposit can be demonstrated by its external relationships, its unmodified shape and surface features, and its uphill changes in lithology. This and many other earthflows formed in postglacial time. In nearly all flows it is possible to identify one or more of the three bedrock components known to have been involved. The several components were transported, mixed, redeposited, and (locally and superficially) relithified by dehydration of altered volcanic ash. 
Eocene trachybasalt, whose remnants are mapped at the base of Sepulcher Mountain, presumably was deposited in an ancestral Yellowstone River valley cut through dacitic breccia before andesitic breccia was deposited. It is quite possible that Eocene landslides moved into that valley, around and over the trachybasalt, in much the same way that the Quaternary ones did, but we cannot prove Eocene landsliding here. We attach no primary stratigraphic significance to very local deposits of dacitic or mixed breccia above trachybasalt at the south edge of the mapped area.

Recent faults along the front of the basalt-covered bench northwest of Gardiner indicate a peculiar type of landslide caused by earthquakes and a combination of other special circumstances. Because of their nearness to the Gardiner fault and a somewhat indirect genetic association, the superficial faults are discussed in the section "Structure." In part of that area, as well as the Sepulcher Mountain area, it was necessary to use arbitrary contacts and a special Quaternary map unit to designate material that has been fragmented and moved too much to be bedrock but is too coarse grained and contains too much landslide material to be ordinary colluvium. In addition to landslide blocks, the basaltic surficial unit includes abundant Holocene talus that was not mapped separately.

\section{ALLUVIUM AND COLLUVIUM}

Alluvium ranges from fluvial deposits of latest Pleistocene age to modern stream deposits. The oldest alluvium is gravel in an abandoned channel several hundred feet above the Gardner River at Eagle Nest Rock. It is possible that this does not represent an ancient level of deposition for the Gardner River but does represent an upper Pleistocene kame terrace on the side of the valley.

Younger and topographically much lower alluvium is deposited on remnants of at least four different terraces near the mouth of the Gardner River and the town of Gardiner from the level of the present rivers to about 150 feet above them. The most extensive surface is a high one at about the level of the town of Gardiner. Gravels on this surface are outwash of Pinedale age mixed locally with moraine. Lower terraces, most conspicuous along the Gardner River, are veneered with material that was reworked as the valley fill was dissected in latest Pleistocene and Holocene time. Southwest of the line formed by the Gardner and Yellowstone Rivers, most glacial deposits and terraces have been destroyed or covered by earthflows. Old high-level benches remain in a few places (Waldrop and Hyden, 1963, fig. 182.3), but no mappable alluvium was found on them.

Even though relatively old alluvium found above stream level has been mapped with young alluvium found closer to the streams, the 
part of the geomorphic record represented by all mapped deposits is very short. Glacial till, old outwash, Yellowstone Tuff, and other deposits of Pleistocene age are considered elsewhere in the report.

Colluvium mantles much of the area, particularly the Precambrian part north of the Yellowstone River. This debris has been mapped only where it obscures the post-Precambrian structure and bedrock contacts.'In places poorly defined glacial or alluvial deposits merge imperceptibly with colluvium or change into colluvium by downslope movements, so that the surficial contacts are picked arbitrarily. The coarse-grained colluvium that is partly or wholly landslide debris has been described previously.

\section{STRUCTURE}

\section{REGIONAL RELATIONS}

The Beartooth uplift is an elongate, arched, fractured, and nearly rectangular block about 80 miles long and 40 miles wide. The uplift trends $\mathrm{N}$. $60^{\circ} \mathrm{W}$. and is bounded in most places by large high-angle faults (Foose and others, 1961). The Gardiner area (fig. 1; pl. 1) straddles the southwest edge of the Beartooth block, where the Gardiner fault is the boundary structure. Northeast of the fault the uplifted Beartooth block is stripped of its sedimentary cover down to the Precambrian and veneered with patches of Cenozoic volcanic rock, but southwest of the fault the down-dropped block, which contains the Yellowstone valley, Mount Everts, and Sepulcher Mountain, retains a section of Paleozoic and Mesozoic rock about 10,000 feet thick. The sedimentary rock dips away from a structural high in Yellowstone National Park and toward the Gardiner fault, but it is curled up and locally overturned along the fault to form an asymmetric syncline.

The Gardiner fault probably extends northwest across the Gallatin and Madison Ranges (Peale, 1896; Iddings, 1904; Wilson, 1934a; Horberg, 1940) and may extend southeast across the Absaroka Range (Wilson, 1934a), which would make its total length about 140 miles, but large areas are covered by Cenozoic volcanic rock so that continuity is in doubt. Transverse north- to northeast-trending faults bound a graben in the down-dropped block southwest of the Gardiner fault, determine the structural grain of the Gallatin Range, and in other areas are the short-direction boundaries of the Beartooth uplift (Horberg, 1940; Foose and others, 1961).

In this report the term "Laramide" is used for the time interval between deposition of the last preserved Cretaceous formation and the first preserved Tertiary formation. This stratigraphically lost 
interval, perhaps 20 million years long, was the time of the most intense differential uplift, deformation, and erosion since the Precambrian. Though the height of the region above sea level may have doubled since then, nearly all structural relief across the Gardiner fault was acquired in Laramide time when Paleozoic and Mesozoic rocks were stripped from the uplifted block and the major faults and folds were formed. The northwest end of the Beartooth uplift was reactivated in Quaternary time, but only 400 feet of Quaternary movement can be demonstrated on the Gardiner fault at the west edge of the mapped area.

Many workers have postulated a Precambrian influence on Laramide structure in the Beartooth uplift, but there is no consensus on the extent to which the Precambrian anisotropy controlled later structure. Foose, Wise, and Garbarini (1961, p. 1152, 1153) summarized the evidence and expressed some skepticism about an absolute Precambrian control. In the Gardiner area we found no evidence for Precambrian control. The Gardiner fault, one of the principal boundary faults for the Beartooth uplift, strikes at a high angle to the schistosity and to the major inferred Precambrian folds. There is no evidence in the Precambrian rocks or in Paleozoic and Mesozoic rocks deposited across the Gardiner fault that the fault was active before Laramide deformation began. Similarly, we found no Precambrian plutons whose size, shape, and alinement suggest that the Beartooth uplift is a reactivated pluton.

\section{GARDINER FAULT}

Structural relief across the Gardiner fault was at least 10,000 feet before mid-Eocene time, for that is the thickness of Paleozoic and Mesozoic beds that was stripped from the uplifted Beartooth block before the dacitic breccia was deposited. Patches of dacitic breccia deposited on Precambrian rock of the uplifted block remain as little as 250 feet vertically from sedimentary beds in the downthrown block, which indicates that nearly all differential uplift across the fault was Laramide. If drag and shear zones in both blocks are considered and allowance is made for erosion of some Precambrian rock, then net shift across the fault zone must have been considerably more than 10,000 feet. Apparent movement was nearly all dip slip, and most of that can be considered as throw if the average dip angle is as steep as it seems.

DIP

At the level now exposed by erosion, the Gardiner fault appears to be a high-angle reverse fault or upthrust. Published cross sections 
show it variously as a vertical fault (Iddings and Weed, 1894; Calvert, 1912), a moderately low angle thrust dipping $35^{\circ} \mathrm{NE}$. (Wilson, 1934a), and a high-angle thrust steepening downward and flattening upward (Brown, 1961, p. 1190). Brown's conception fits the regional picture deduced for the Beartooth uplift (Foose and others, 1961) and is the theoretical view favored here, but evidence for near-surface flattening is slight, possibly because Laramide erosion removed part of the structure.

The precise dip on the Gardiner fault cannot be determined in most places. Proof of high dip is available where the fault crosses the Yellowstone River (pl. 1). There, the fault has a nearly straight trace 1 mile long in spite of the highly irregular topography. A three-point determination shows a high-angle reverse fault that dips $75^{\circ} \mathrm{NE}$.

Elsewhere, the fault must also be steep, but cover, bifurcation, or strike changes prohibit meaningful three-point determinations. In areas where sedimentary rocks crop out adjacent to the fault, most beds are nearly vertical. Extreme overturn generally occurs some distance from the fault and in some places is the result of surficial creep rather than primary structure. Where overturn is primary, it is local and is associated with shear zones, weak and highly deformed stratigraphic zones, or small derivative thrusts in the 1-mile-wide drag and shear zone of the downthrown block. Most derivative thrusts are flatter than the master fault. Wilson (1934a, fig. 6) measured the $35^{\circ}$ dip about 1,400 feet southwest of where we place the main Gardiner fault (pl. 1).

Just west of the mapped area at Little Trail Creek and farther northwest at Cinnabar Mountain, Precambrian rock appears to be in nearly vertical contact with vertical sedimentary beds. At Cinnabar Mountain none of the sedimentary section is missing from the downthrown block. Nowhere did we find Precambrian rock in low-angle thrust contact with sedimentary rock. There are no klippen or windows. The trace is not sinuous enough to indicate more than moderate strike changes in a high-angle fault or (outside the mapped area) offsets on cross faults. (Compare pl. 1 with Iddings and Weed, 1894, Calvert, 1912, and Wilson, 1934a.) Steep Eocene(?) dikes in the fault zone northwest of the mapped area, the very large Quaternary deposit of travertine on the fault zone, and Quaternary reactivation all suggest a high-angle fault.

\section{IARAMIDE STRUCTURE IN THE DRAG ZONE}

In areas not covered by basalt, most visible structure in the drag zone of the downthrown block is Laramide, not only because the 
Laramide deformation was more general and much larger but because few Quaternary structures can be detected where the brittle caprock is missing. In Laramide time the drag zone was flexed and broken and then, as some 2 miles of rock sheared past it at a high angle, was curled upward to or beyond the vertical, sheared and stretched vertically, squeezed horizontally, and intricately faulted. In most places the lower part of the stratigraphic section was cut out at depth, and nearly vertical Cretaceous beds are in steep fault contact with crystalline Precambrian rock.

The minor structures described below probably have little relation to the family of larger upward-flattening thrusts and overfolds that have been found or predicted by theory along mountain fronts adjacent to other upthrusted areas (Bengston, 1956; Sanford, 1959; Foose and others, 1961; Berg, 1962; Howard, 1966). The Gardiner area differs from most other faulted mountain fronts (and from laboratory and mathematical models) either because the uplift continued longer, thus exposing and continuously modifying the steep root zone, or because there was no large adjoining basin dipping away from the mountain front and into which the uplifted mass could expand. Whatever the reason, the large flat thrusts of the foreland are missing here, and the small ones that are found, with the possible exception of the Everts fault, seem not to be the roots of larger ones.

Among the drag-zone structures that seem definitely to be Laramide is the Everts fault (pl. 1; Wilson, 1934a; Brown, 1961), which marks the outer edge of the drag zone in the southeastern part of the mapped area and perhaps elsewhere under cover. The Everts fault is a thrust that is much smaller and probably flatter than the Gardiner fault. The asymmetric syncline that was formed by drag collapsed as its steep limb, the drag zone, moved up and southwest on the Everts fault.

The imbricate area of miniature thrusts and folds (pl. 1) is the most highly deformed segment of the drag zone. The most conspicuous miniature thrusts are at the stratigraphic top of the overturned competent Quadrant Quartzite and the Cloverly Formation, but other thrusts, not all mappable and some essentially bedding-plane faults, occur throughout the section. The area is segmented by small tear faults that commonly pass into thrusts. Though generally transgressive and flatter than the Gardiner fault, nearly all the miniature thrusts begin and end in the stratigraphic section between the Madison Limestone and the Eagle Sandstone. The small plates did not move beyond the drag zone to overthrust the gentle limb of the syn- 
cline, and heave on individual faults is probably less than 1,500 feet even at points of maximum stratigraphic displacement.

There are geometric reasons why the miniature thrusts did not and could not develop into major faults. They began in the nearly vertical drag zone, which is much too small a source for major thrust plates. Even if all structure within the imbricate area is Laramide and orogenic (a doubtful assumption), the thrusts and the overfolds have a shallow flaplike form that limits their size. An essentially orogenic mechanism for deriving flat subsidiary thrusts from a highangle master fault is diagramed in figure 3. Another possible mechanism-overfolding and near-surface collapse-is shown diagrammatically in the cross section of plate 1 .

\section{SURFICIAL MODIFICATION OF DRAG-ZONE STRUCTURE}

The transverse Mammoth fault, which seems to be mostly Laramide in age in this area, offsets miniature thrusts in the imbricate

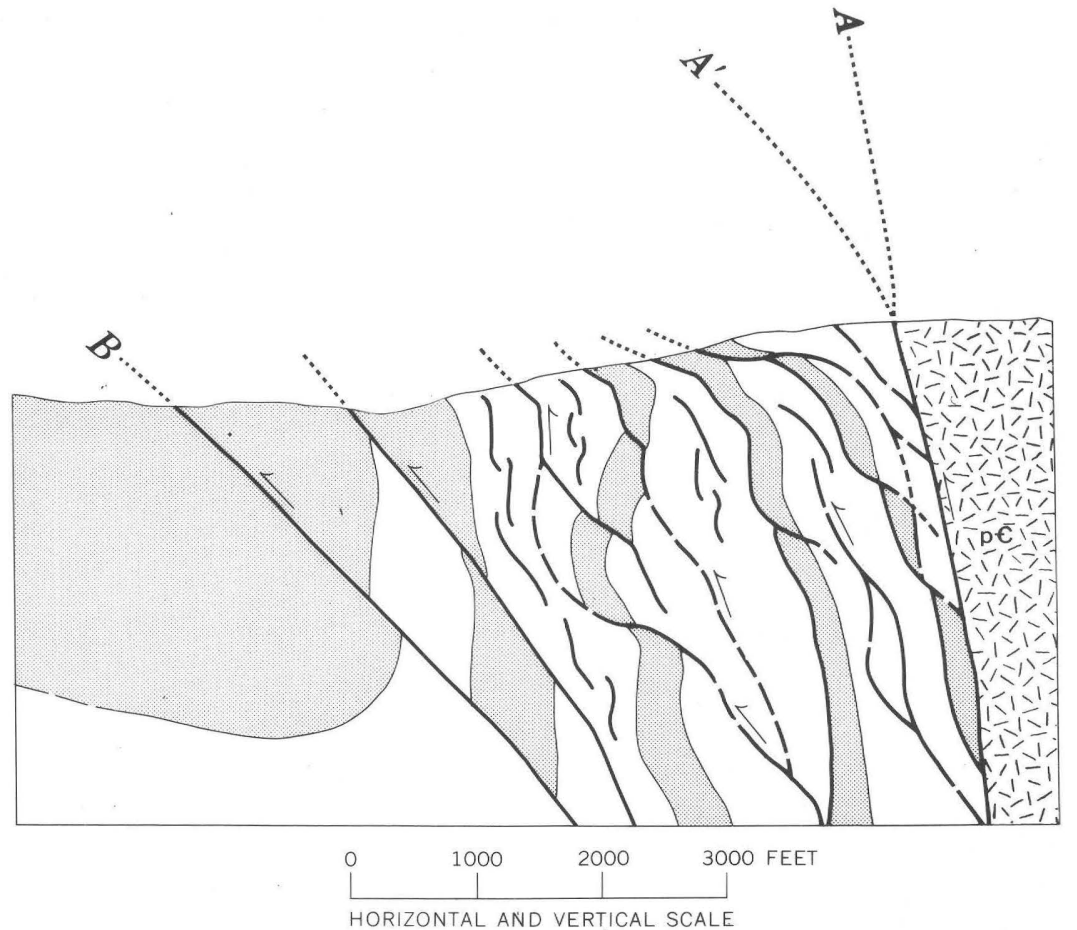

FIGURE 3.-Diagram illustrating how competent beds (shaded) can be irregularly pulled apart vertically and squeezed together horizontally to pinch out the incompetent beds in the downthrown drag and shear zone adjacent to a high-angle fault. Master fault $A$, which could have begun as a vertical or normal fault, mushrooms outward $\left(A^{\prime}\right)$ as flatter derivative thrusts develop between $A$ and $B$. Near-surface creep also overturns beds and flattens faults. $\mathrm{\ell}$, Precambrian rocks. 
area (pl. 1). Near the Jardine road in sec. 24, T. 9 S., R. 8 E., Pliocene(?) basalt was deposited on an already emplaced thrust plate of overturned Quadrant Quartzite. Therefore, it is reasonable to assign most of the thrusting to the Laramide deformation.

However, as noted above, extreme overturning appears very shallow and probably has a flaplike form. Shallow structure is conspicuous in sec. 19, T. 9 S., R. 9 E., where trails on the Cody Shale are being disrupted today by small unmappable creep folds, slumps, and superficial faults. In one place a nearly flat thrust segment of Quadrant Quartzite, possibly a superficial flap, is broken by a normal fault (pl. 1), which probably is superficial and Holocene like most normal faults that break flat-lying basalt to the northwest (pl. 1). Deep strike gullys downhill from nearly vertical beds may have permitted, and may yet permit, short fault-bounded segments of steep beds to form superficial flaps. Regardless of when such modifications of orogenic structure occur, locally they increase the stratigraphic displacement on existing thrust faults, and they overturn or flatten the dips on steep beds or faults. Similarly, a very localized and shallow cascade of Cretaceous shale moved downhill along the range line between secs. 19 and 24 in what seems to be a superficial modification of existing folds and thrusts. This evidence for Holocene gravity-collapse structure suggests, along with the discontinuity and small scale of the other imbricate structures, that even the Laramide structure may be partly superficial, because a deep ancestral Yellowstone River valley existed here in late Laramide time and was protected at several different times by thick volcanic deposits.

\section{QUATERNARY REACTIVATION OF GARDINER FAULT}

Northwest of Little Trail Creek at the west edge of the mapped area (pl. 1), a small patch of Pliocene(?) basalt north of the Gardiner fault is perched about 400 feet higher than remnants of the same basalt just south of the fault. Only the northwest end of the Gardiner fault segment considered here seems to have been involved in this late-stage reactivation. Displacement probably dies out to the southeast and increases to the northwest.

Neither the base nor the top of the basalt is a reliable datum to evaluate the Quaternary reactivation because the cross-sectional shape of the ancestral Yellowstone valley is unknown and differential erosion has removed the basalt top in places. Nevertheless, these are the only available datums. One could postulate a Yellowstone valley filled with basalt to the level indicated north of Little Trail Creek, which would eliminate all Quaternary movement; but this would require 800 feet of basalt, and no available evidence supports such. a thickness. 
The base of the basalt directly across the fault is 400 feet lower than the lowest part of the base at the perched exposure (figs. 4, 6; pl. 1). The five perched flows total about 300 feet in maximum thickness. Five to 6 miles upstream along the Yellowstone River at Deckard Flats, on the same side of the river and on the upthrown side of the Gardiner fault, five similar flows also total 300 feet in thickness, but here both top and base are 400 feet lower than in the perched exposure. We found no evidence for more than five flows, for more than 300 feet of basalt, or for a major stream reversal since basalt deposition. Neither the perched basalt nor the basalt at Deckard Flats was appreciably eroded. The basalt-covered bench, 400 feet lower than the perched basalt and including Deckard Flats, must represent to a first approximation the flat floor of the ancestral Yellowstone River valley.

The above data show that the perched basalt at Little Trail Creek was uplifted to its present position, not deposited there, and that deformation dies out upstream. If there had been no deformation, basalt at Deckard Flats would be slightly higher than the perched

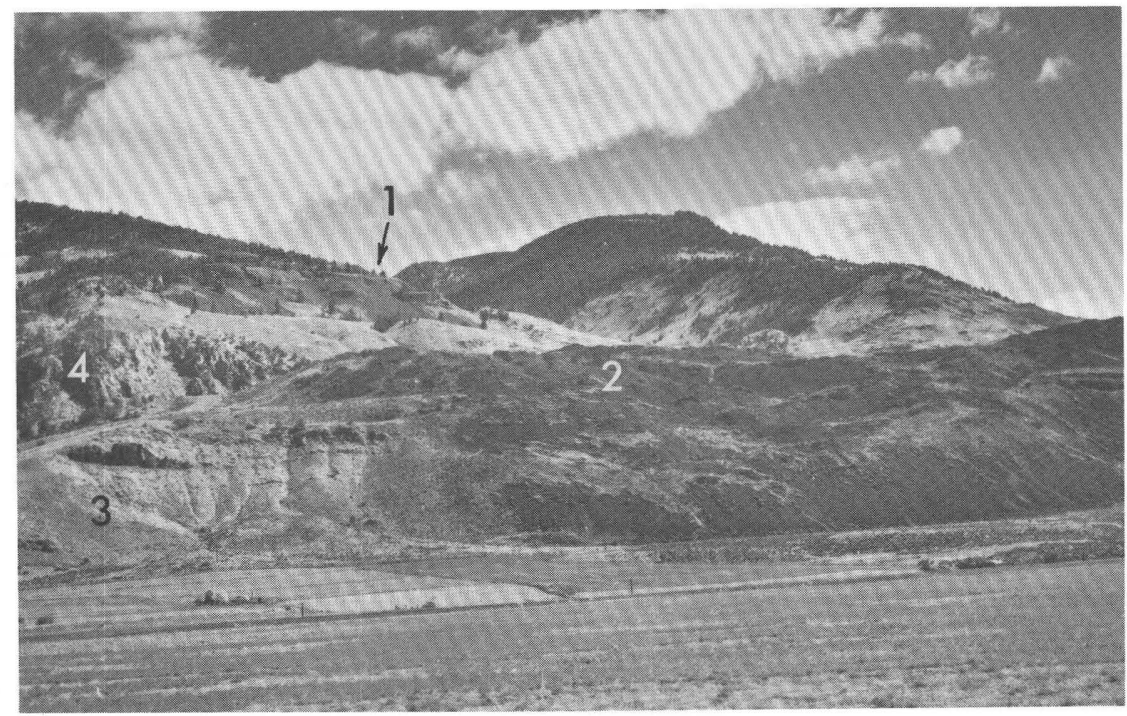

FIgURE 4.-View nontheast across Gardiner fault and drag zone at elbow in Little Trail Creek. 1, Uplifted Pliocene(?) basalt 400 feet above, 2, superficially faulted basalt on dropped side of reactivated Gardiner fault, resting on, 3, overturned Landslide Creek Formation that dips toward fault and shows dark lenses of andesitic boulder conglomerate. Laramide Gardiner fault trace follows lower, northwest-flowing segment of Little Trail Creek at contact between sedimentary rock and, 4, Precambrian granite. Note parallelism of sedimentary beds and superficial faults in basalt. Most overturning is superficial, as reflected in broken and tilted basalt. 
basalt instead of 400 feet lower. Similarly, because of stream gradient, the basalt base at Deckard Flats should be slightly higher than it is in the downthrown block at Little Trail Creek. Because this is not true, one can postulate a slight upward drag in the downthrown block at Little Trail Creek.

Quaternary uplift at Little Trail Creek was not concentrated in the principal Laramide fault plane between Precambrian and Cretaceous rocks or in any single fault between the perched basalt and the main Gardiner fault. Rather, the differential uplift seems to have been distributed across about 1,500 feet of the shear and drag zone in the upthrown block and, at this level, may be more nearly a monoclinal flexure than a fault. This is because no fault scarp is present in the upthrown block, and Eocene dacitic breccia, located between the Gardiner fault and the perched basalt, is not uplifted as much as the basalt. That the deep faulting which caused this flexure may have broken through to the surface locally is indicated by poorly defined shear-breccia zones and by young colluvial deposits, both of which are cemented by calcium carbonate derived presumably from hot springs.

The minor uplift indicated by displaced Pliocene(?) basalt includes all or nearly all differential uplift across the Gardiner fault zone in this area since deposition of the Eocene dacitic breccia. Reactivation probably began in Pleistocene time, because that is when travertine deposition began along the fault zone. Also, prior to the last glaciation, the basalt bench was more deeply eroded near Little Trail Creek than it was upstream, which suggests a localized Pleistocene hump in the Yellowstone valley. However, part of the deformation must have been Holocene, because nearly all visible faults adjacent to the Gardiner fault in the downthrown basalt bench are Holocene.

\section{MINOR QUATERNARY STRUCTURES}

The obscure surficial structure noted in the imbricate area east of Gardiner becomes obvious and takes on a different character in the basalt-covered area 3 miles long and half a mile wide between Gardiner and Little Trail Creek. Here there are countless fissures, normal faults, and tilted fault blocks, mostly of Holocene age, and they are not all mappable on the scale of plate 1 . The faults are visible only within or above Pliocene(?) basalt and only where it was deposited on weak sedimentary beds in the drag zone of the downthrown block. The originally horizontal basalt, though it may have overloaded the once-vertical sedimentary rock, probably was more important in preserving young structures than in forming them. Moreover, the brittle and resistant character of the basalt may 
account for the large size of some faults because each minute displacement can be preserved and then the next displacement increases it. Sudden earthquake displacements and gradual creep or slump displacements were recorded and integrated in the basalt. West of the mapped area, where basalt has been stripped away, faults seem to vanish abruptly in bedding planes, contacts, and strike gullys, apparently because erosion erases the scarps as fast as they form.

Most Quaternary faults strike in a northwesterly direction, roughly parallel to the Gardiner fault and to subjacent bedding. planes, and they range from tiny irregular fractures to straight faults that have 100 feet of throw and are more than 1 mile long. Generally they are downthrown on the southwest, or Yellowstone valley, side, but some individual and clustered faults moved in the opposite direction. In places there are horsts and grabens. Near the Gardiner fault a long, narrow, straight graben dropped 100 feet (fig. 5). The basalt-covered tops of most blocks are tilted southwest, some more than $60^{\circ}$.

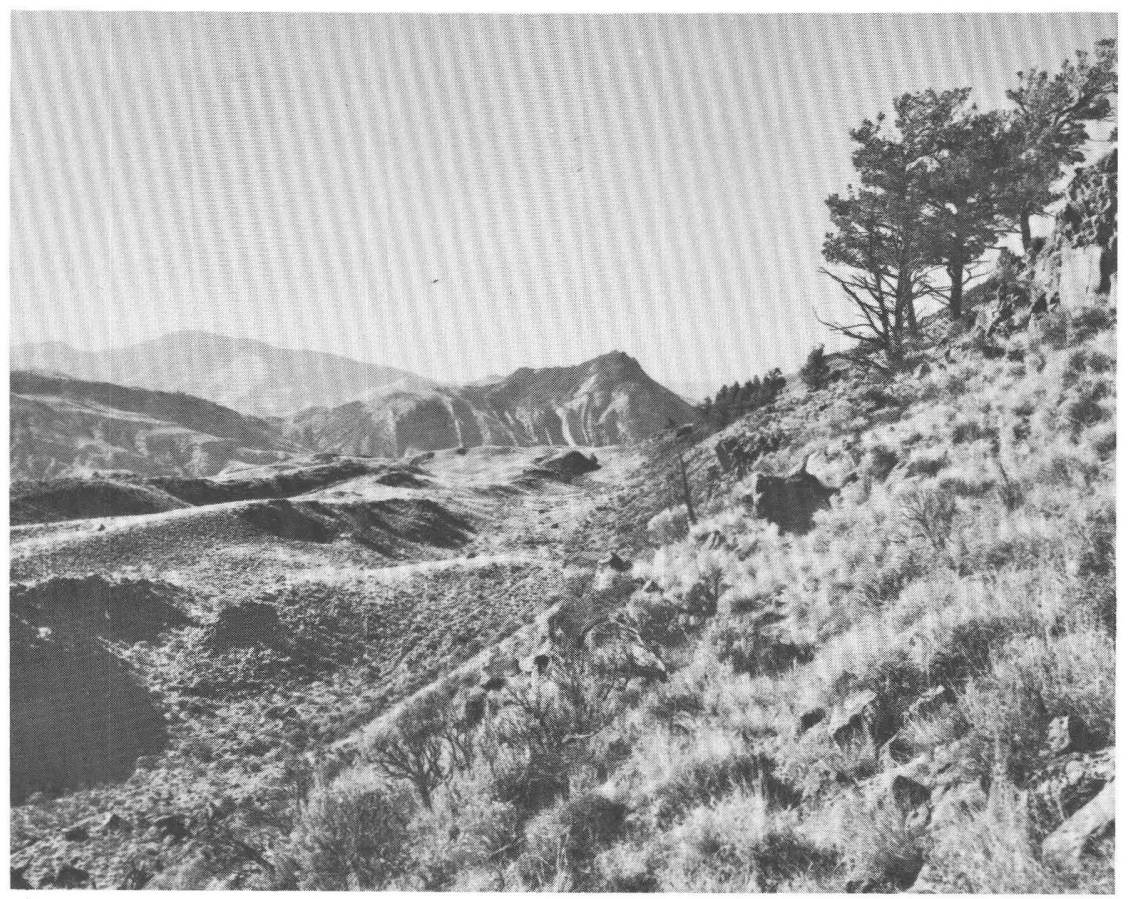

FIGURE 5.-View along axis of Quaternary graben in Pliocene(?) basalt, looking diagonally across the concealed Yellowstone River (flowing right) and toward Cinnabar Mountain (in the distance). Basalt is underlain by weak, nearly vertical Cretaceous beds. Note basalt blocks tilted left, toward Yellowstone valley. 
Disruption of the basalt bench is diagramed in figure 6 and discussed further in succeeding paragraphs. Though some orogenic structure undoubtedly is present in the basalt bench, most conspicuous structure is superficial. Massive creep along the front of the bench clearly belongs to the superficial category, as do the earthquakeinduced slumping and lurching. Bedding-plane slip or slippage along older faults during earthquakes, perhaps the dominant kind of failure found here, produces faults that grade into rather large structures. Some of these, the inferred flexure or drag of sedimentary rock beneath basalt, and the uplift of the Beartooth block are clearly orogenic, though, of course, minor and in a sense superficial when compared with the much larger Laramide structures.

Sedimentary rock in the frontal zone all along the basalt bench is moving toward the Yellowstone valley by a combination of creep and slump and is lubricated in places by thick bentonite layers. Removal of material at the front allows basalt-covered blocks farther back to settle differentially. Generally, the large-scale frontal processes are obscured by a thick veneer of basalt talus and glide blocks through which one must climb to reach the fault blocks on top of the bench, but obscure scarps in the talus can be traced into contacts or bedding planes in exposed pockets of bedrock. Moreover, in one place at the west edge of the mapped area, where a slab of basalt is still attached to its sedimentary floor, the basalt is tilted steeply southwest and the sedimentary beds are overturned steeply. The tilt angle in the basalt is the complement of the dip angle in the beds. Thus, before the basalt was pulled apart, the sedimentary drag zone was essentially vertical. The conspicuous overturning at the front of the bench is due to local Holocene creep unrelated to Laramide movement on the Gardiner fault and related only indirectly and superficially to Quaternary movement on the Gardiner fault.

In an area closer to Gardiner, Howard (1937, pl. 7, fig. 2, p. 66) photographed and described inclined basalt that he interpreted as a dike dipping southwest. In our opinion this is not a dike but another tilted slab. Not all southwesterly tilt results from creep in the sedimentary bedrock; some results from free gliding down the frontal slope. Reverse tilt observed in some areas is interpreted as a consequence of toreva-block slumping or, farther back on the bench, differential settling.

The top of the basalt-covered bench can be divided transversely into three poorly defined segments characterized by different patterns. In the travertine- and till-veneered segment closest to Gardiner, many fault traces are concave downhill. These faults indicate large slump blocks. Further northwest is a segment that contains the long, 


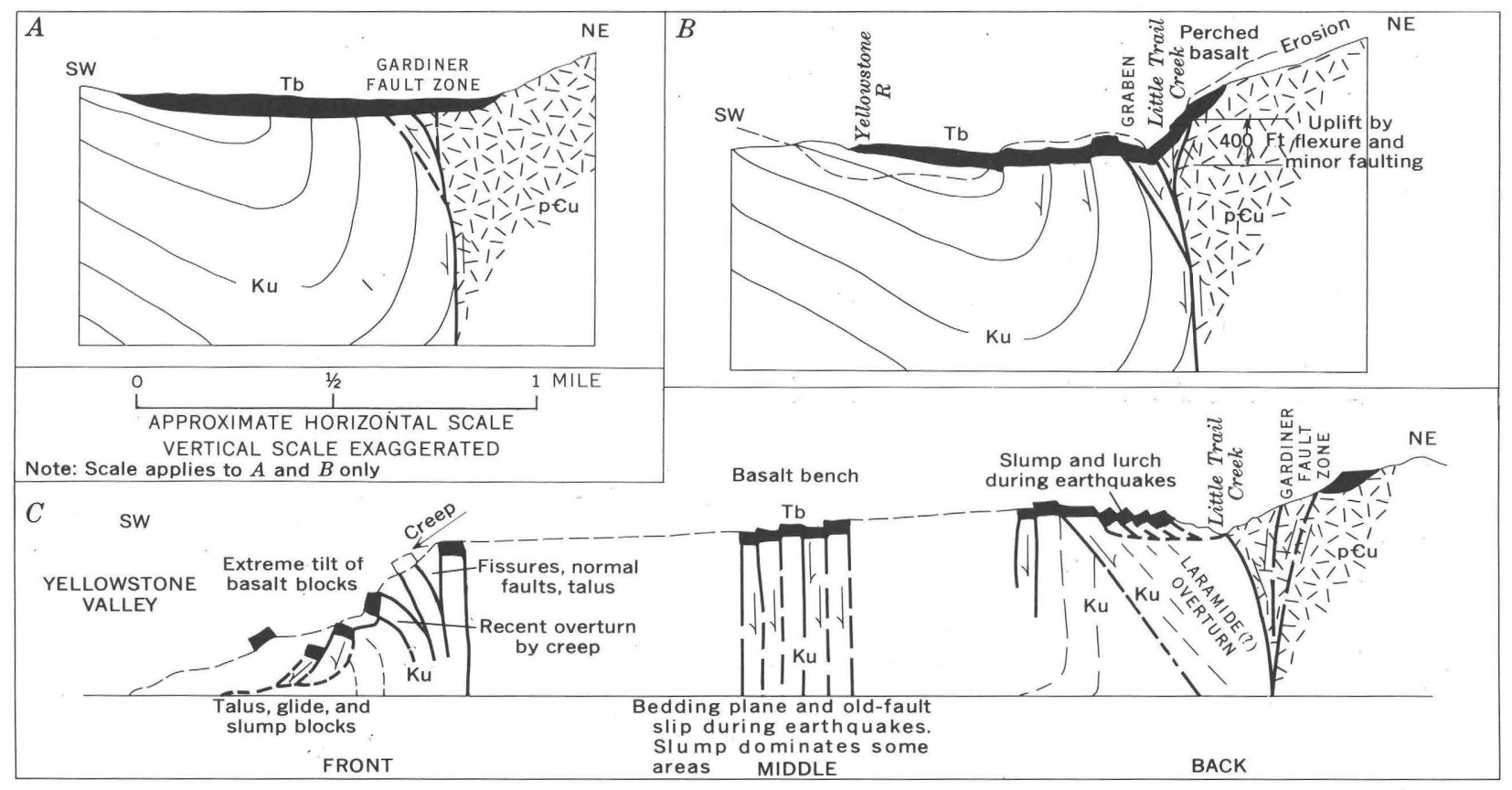

FIGURE 6.-Diagrammatic cross sections showing Quaternary disruption of basalt near Little Trail Creek. Tb, Pliocene(?) basalt; Ku, Cretaceous strata undivided; $p € u$ Precambrian rock undivided. A, Flat lying basalt before orogenic deformation. $B$, Orogenic deformation (greatly exaggerated) before superficial modification; subsequent erosion removed rocks above dashed line, thinned them below line, and provided relief into the Yellowstone River and Little Trail Creek valleys. $O$, Earthquake-related fault modification of orogenic deformation accompanied and followed by slump and creep. Not to scale. 
straight faults and the large previously noted graben. Faults in that segment probably are controlled by bedding or old Laramide faults. A relationship to the reactivated Gardiner fault and to earthquakes also is likely. South of Little Trail Creek, just outside the mapped area, are numerous small fault blocks which, when viewed from a distance, look like a row of dominoes tilted toward the Yellowstone River (figs. 6, 7).

Throw on each of the dominolike blocks is only 10-15 feet and is down on the Little Trail Creek side; a plane through the upper edges slopes slightly toward Little Trail Creek. Slump and lurch into nearby valleys during earthquakes is the explanation favored here (fig. 6C, this report; Richter, 1958, p. 59, 124). Southwest of the small blocks, larger ones are displaced in the more usual mannerthat is, down on the Yellowstone River side. Bedding-plane slip during earthquakes may explain these structures.

\section{AGE OF THE YOUNG FAULTS}

The basalt surface has been glacially eroded, grooved, and polished, and erratics litter the area. But countless fissures and scarps are not

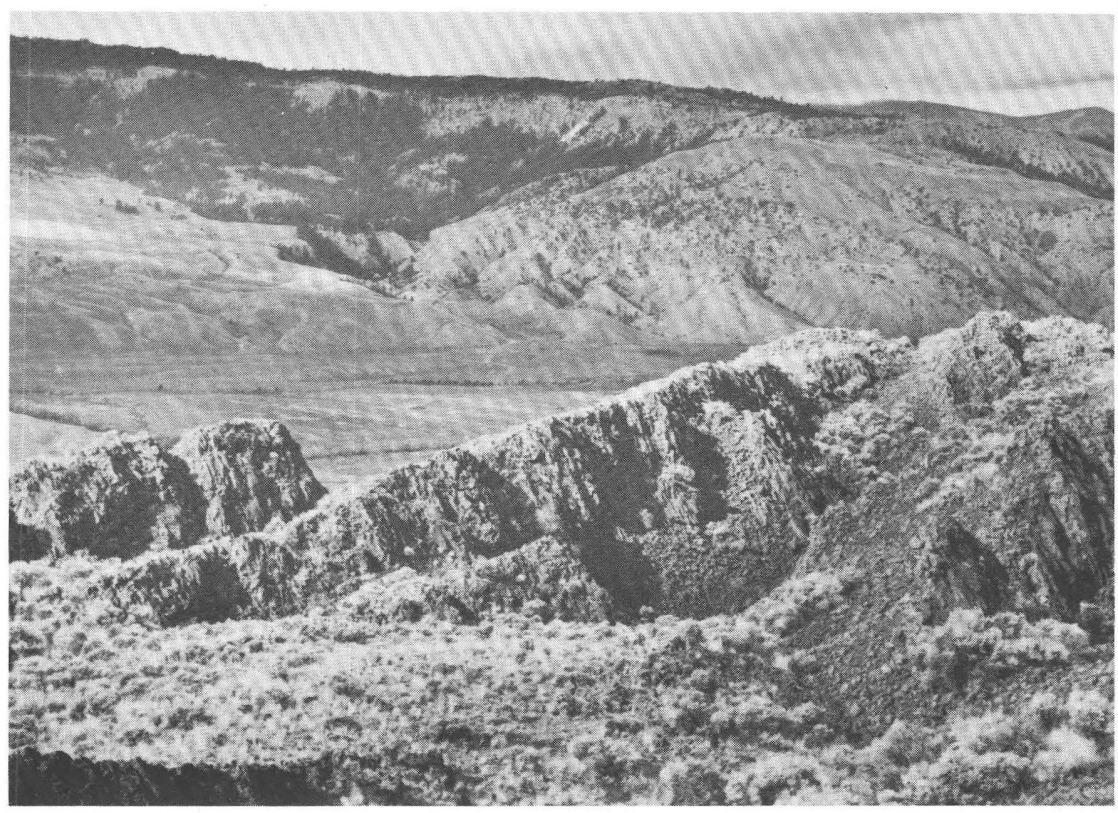

FIGURE 7.-View southwest across westernmost edge of the basalt-covered bench near Little Trail Creek. Holocene superficial scarps are 10-15 feet high. Upper surface of Pliocene(?) basalt is glacially polished; scarp faces are fresh, indicating postglacial faulting. Note that each block moved down toward the right (Little Trail Creek) and is tilted left, toward the Yellowstone River valley. 
glacially eroded, talus is fresh, and no till was found impacted in fissures and grabens. Thus, nearly all datable structure is at least partly Holocene. This is disturbing because, from previously cited evidence, it seems that Quaternary uplift began here in Pleistocene time. One plausible explanation for the apparent time lag between uplift and faulting is that glacial erosion probably did modify some older scarps but Holocene movement rejuvenated them and new talus covered till. Doubtless, postglacial incision of the Yellowstone valley increased instability, which marle all downhill movement easier. Removal of ice from the valley and thawing of permafrost may have helped Holocene gravity collapse. It is possible, therefore, that the principal Quaternary orogenic activity-uplift at Little Trail Creek and formation of some larger faults-was Pleistocene, but the principal modification - pulling apart and tilting of blocks by earthquake shaking, creep, and slump-was Holocene.

Examination of the Hebgen Lake area, 25 miles southwest of Gardiner, immediately after the 1959 earthquake showed earthquake damage patterns qualitatively similar to the fissure and normal-fault pattern near Gardiner. Of particular interest there are the sags and grabens developed in the downthrown block adjacent to a fault scarp or monoclinal flexure (Witkind, 1964a, b; Myers and Hamilton, 1964; Fraser and others, 1964). Sags and grabens are conspicuous in surficial deposits, but they also occur in unstable bedrock and are characteristic of earthquake deformation. A good example of a graben in the Gardiner area has been previously described (p. 70).

\section{EARTHQUAKES}

Destruction of the basalt bench is not a uniform process nor is it completely spontaneous. Doubtless, more fault damage has been done during a fow violent earthquakes than during thousands of years of slow erosion and creep, for this is an earthquake area. Recent fault scarps, some probably only a few hundred years old, are present 15-20 miles downstream (Horberg, 1940, p. 280; John de la Montagne, oral commun., 1963), and about 5,000 years ago a landslide similar to the one that dammed the Madison River during the Hebgen Lake earthquake (Hadley, 1964, p. 107-121) dammed the Yellowstone River 10 miles downstream from Little Trail Creek (Good, 1965).

Steep bedding planes became faults in a very large area around the Hebgen Lake epicenter. These faults were smaller than the ones at Gardiner-slip rarely exceeded 1 foot and generally the length was less than one-fourth mile. However, the bedrock in which nearly all larger faults at Hebgen Lake occurred was covered by colluvium; 
some large faults may have been bedding-plane structures at depth, and many were reactivated faults. Certainly, reactivated faults, whether bedding-plane structures or not, are probable in the steep drag and shear zone of the Gardiner fault. Slip on such structures during an earthquake is not primarily a creep phenomenon. In this region it is mainly high-angle faulting in which the free, or valley, side drops down, and this may explain why most faults in the basalt bench are downthrown to the southwest.

Because earthquakes recur for thousands of years in the same fault zones, more earthquake activity at Gardiner is possible. Earthquakes cannot be predicted, evaluated, or located in advance, but rough estimates based on the 400-foot uplift at Little Trail Creek suggest that a large earthquake every $500-1,000$ years is possible along the Gardiner fault zone. Moreover, it is not necessary in an unstable area for the epicenter to be precisely in the area for some damage to occur. A large earthquake 10-20 miles away could damage the Gardiner area.

New motels and homes have been constructed along the base of the basalt bench near Gardiner. Though there is little evidence for catastrophic landslides at that locality, there are places where landslides could occur, and large blocks did tumble downslope into areas now occupied. The safest guide to future development is probably the evidence of what happened in the recent past. Thus, it is unwise to build on or below the steepest slopes or where large blocks have rolled. Buildings should be well braced, masonry should be reinforced, and large masonry structures should be avoided.

\section{TRANSVERSE FAULTS}

\section{MAMMOTH FAULT}

Three major high-angle northeast-trending faults transverse to the Gardiner fault near Gardiner were postulated by the early workers, but only one fault is within the present mapped area, and it was not shown on the early maps. This fault, which extends down the valley of the Gardner River (Iddings, 1904, p. 101) and probably localizes the famous hot springs at Mammoth, Wyo., was named the Mammoth fault by Brown (1961, p. 1186, 1190). The Mammoth fault forms the east margin of what may be termed the "Sepulcher graben," a transverse structure that butts into the Gardiner fault at a high angle but does not offset it visibly or cross into the Beartooth block (pl. 1; Iddings, 1904, p. 101).

The Mammoth fault is covered in most places but is indicated near Eagle Nest Rock where the Landslide Creek Formation apparently has been dropped to about the same level as the older, Telegraph 
Creek Formation. Stratigraphic throw at that point exceeds 2,000 feet. Probably the same fault or a branch of it is indicated further north near the Yellowstone River and in the imbricate area where north-dipping overturned beds and miniature thrusts have been differentially offset.

The drag zone of the Gardiner fault was intricately and differentially deformed before and, to a lesser extent, during transverse faulting, probably was modified by superficial collapse, and is now partly covered, so that precise calculation of throw on the Mammoth fault near its junction with the Gardiner fault is impractical. Two approximations based on different offsets in different beds indicate close to 1,500 feet of stratigraphic throw. This figure seems reasonable. Because the offset of steeper beds seems to be systematically less than that of flatter beds, except where superficial movement can be inferred to have reduced the structural offset, dip slip rather than strike slip is the preferred explanation of the offset.

The junction between the Gardiner and Mammoth faults and a large area around it is covered so that no offset of the Gardiner fault can be detected. Moreover, it is possible that there is little or no offset. If the Gardiner fault is nearly vertical, throw on the Mammoth fault could be expressed simply as increased throw on the Gardiner fault west of the junction, but if the Gardiner fault dips $35^{\circ}$ as postulated by Wilson (1934a, figs. 3, 6), the large offset $(2,000 \mathrm{ft})$ shown by Wilson is more probable. Wilson's hypothesis implies, however, that the Mammoth fault extends into the Beartooth block. He does not show this, and we found no evidence for it.

If the Sepulcher graben does not penetrate the Beartooth block, it can only serve to increase throw on the high-angle Gardiner fault along the north end of the graben. This hypothesis finds some support in the unusual amount of sedimentary rock that remains along the Gardiner fault west of the Sepulcher graben at Cinnabar Mountain.

\section{AGE}

Throughout the elevated Beartooth-Gallatin region of which the Gardiner area is a part, enclaves of sedimentary rock were preserved from Laramide erosion because they were not uplifted as much as adjacent areas. Relative downdropping of the sedimentary blocks occurred along major faults, most of which trend northwest like the Gardiner fault (Ross and others, 1955), but there is evidence that the transverse faults also were active in Laramide time. Recent work in Yellowstone National Park by Edward T. Ruppel and William R. Keefer (oral commun., 1968) confirms and amplifies the suggestions by Iddings (1904) that many north-trending faults are at least 
partly post-Laramide. Some north-trending faults show Quaternary movement. The question here is the age of the principal movement, particularly on the faults that bound the Sepulcher graben in and near the Gardiner area.

The Gallatin Range is bounded on the east by north-trending faults. Early reconnaissance showed thick deposits of the oldest Eocene formation (dacitic breccia of this report) adjacent to the Gallatin Range in both the Beartooth uplift and the park, but the same formation was not found in the Gallatin Range. Thick Eocene deposits of andesitic breccia were found in the Gallatin Range, where they rest on Precambrian rock in places (Iddings and Weed, 1894; Hague and others, 1896, Gallatin sheet; Hague, 1904). These distribution patterns permit an incipient Gallatin Range of Laramide age, but they do not rule out later and perhaps greater faults to accentuate the range.

Similarly, the Sepulcher graben seems to have localized a deposit of Eocene dacitic breccia. The graben is bounded on the west by one of the Gallatin Range faults, the Reese Creek fault of Iddings (1904, p. 101), and on the east by the Mammoth fault. The Reese Creek fault has a stratigraphic throw of 4,300 feet near the mouth of Reese Creek, $11 / 2$ miles west of the Gardiner area, and the Mammoth fault has a stratigraphic throw of 1,500 feet near the Gardiner fault on the east edge of the graben. As hypothesized above, formation or reactivation of the graben would reactivate the Gardiner fault. The amount of post-Laramide movement should be indicated by displacement of the dacitic breccia, which covered the Gardiner fault. As patches of dacitic breccia remain in the upthrown block of the Gardiner fault, only 250-500 feet above sedimentary rock in the downthrown block, more than two-thirds of the movement of the Sepulcher graben appears to have been Laramide.

\section{OTHER FAULTS AND FOLDS}

Other faults, some within the Precambrian block and some associated with the Gardiner fault, perhaps as bifurcations, are shown on plate 1. These are not large enough or well enough known to merit extended discussion. They must, however, be representative of a much larger group of fractures that break the area intricately. Unmapped faults in the Precambrian Beartooth block, suggested by straight lines on aerial photographs and by stream patterns, are difficult to prove and may be mostly joints or groups of joints. Faults in some parts of the drag zone are too small, too numerous, or too superficial to be mapped. It is apparent only that the entire region has been highly fractured (Iddings, 1904). 
One small scarp in surficial deposits in the Yellowstone valley at the west edge of the mapped area on the line between secs. 16 and 21 , T. 9 S., R. 8 E., may indicate a Holocene fault. As this may also indicate a former bank of the Yellowstone River, it has not been stressed. This fault(?) could indicate compaction or tectonic dropping of the valley during a Holocene earthquake. Such a feature is certainly compatible with the much more common faulting north of the Yellowstone.

The only major fold known in the area is the syncline formed by drag along the Gardiner fault. The mostly covered axial region of this syncline probably is broken by the Everts and other faults throughout much of its length, and such faults probably increase in number toward the northwest, as indicated by the complex structural pattern across the Yellowstone River in the Electric coal field (Calvert, 1912; Wilson, 1934a).

\section{ECONOMIC GEOLOGY}

\section{COAL DEPOSITS}

Though thin and discontinuous coal beds of low grade have been found in other formations, the only formation that has economic possibilities is the Eagle Sandstone. In former years coal was mined from the Eagle in the Livingston area 40 miles north of Gardiner (Roberts, 1957) and in the Electric (formerly named Cinnabar or Horr) coal field (fig. 1) adjacent to the Gardiner area on the west (Iddings and Weed, 1894; Calvert, 1912; Wilson, 1934a; Combo and others, 1949). At the time the Electric field was being mined, thin beds of coal of similar grade in the Gardiner area, though locally exposed, were ignored because of the vertical or overturned dip, the intense and unpredictable structure, and the (generally) thick cover in the area.

\section{ELECTRIC COAL FIELD}

Because information on the coal of the Gardiner area is scanty, data on the adjacent Electric field is reviewed briefly here. This section is compiled from the sources referred to in the paragraph above, from a written communication (1965) by Paul Averitt, and from field investigations by the authors.

From about 1885 to 1910 , coal was mined from three structurally separate parts of the Electric field whose total productive area is less than 3 square miles. The 300 -foot shale and sandstone sequence above the Virgelle Sandstone Member of the Eagle Sandstone contains all the workable coal, and only one bed, the No. 1 coal of Cal- 
vert, which is about 300 feet above the Virgelle, was extensively mined. Though all coals are lenticular and variable within thicker carbonaceous zones, the No. 1 is most consistent, and generally a bed $11 / 2-5$ feet thick can be identified. The No. 1 coal averages about $31 / 2$ feet thick, including clay and sandstone partings. The No. 2 and No. 3 coals, about 100 feet and 50 feet, respectively, above the Virgelle, though locally as thick as No. 1, are much more variable. The No. 2 and No. 3 coal beds were mined only locally, presumably because they were noncoking in most places or were too deep, too thin, or too variable.

Structure in the three-part field is complex. The Little Trail Creek area lies in the highly deformed drag zone of the Gardiner fault. The Electric and Aldridge districts (Calvert, 1912), on the opposite side of the Yellowstone River 11/2-4 miles west of the Gardiner quadrangle, are in the gentle, or southwest, limb of the syncline formed by drag on the Gardiner fault. In addition, the Electric and Aldridge districts are bounded, broken, and drag-folded by major northeast-trending high-angle faults of the Gallatin Range and by other high-angle faults that trend mostly east. Faults disrupted the coal in every mine, which made mining difficult and hastened closing of the field.

Coal in the Electric field generally ranges from high-volatile $\mathrm{C}$ to medium-volatile bituminous. Locally in fault and drag zones it is semianthracite. In many places it is so highly fractured that it can be shoveled out in small pieces; elsewhere some block coal is present.

Most coal mined in the main Electric and Aldridge districts was converted locally to coke in beehive ovens and shipped to copper smelters at Anaconda and Butte. The operators had difficulty meeting smelter requirements for an ash content of less than 18 percent, but in other respects the coke was apparently of good grade.

According to Paul Averitt (written commun., 1965), "The inferred original resources in the No. 1 bed are $* * *$ about 7 million tons. When this figure is reduced to allow for past production and losses in mining, and estimated future losses in mining, the estimated recoverable resources in the No. 1 bed are on the order of 3 million tons."

\section{LITTLE TRATL CREEK AREA}

Included in the Electric field as mapped by Calvert (1912, pl. 30) is a small area (NE1/4 sec. 8 , NW1/4 sec. 9, T. 9 S., R. 8 E.) designated, for purposes of this discussion only, the Little Trail Creek area. This area lies about half a mile west of the mapped area of the present report. It is separated from the main parts of the Electric field by the large Reese Creek fault (described in the section 
"Structure") and by the Yellowstone River, and it lies on the opposite, steep side of the asymmetric syncline formed by drag on the Gardiner fault. Thus, the Little Trail Creek area is part of the drag zone that continues southeastward to make up the only potentially valuable coal area within the Gardiner quadrangle. Cover and location within the highly deformed drag zone make it impossible to trace coal beds for any great distance. Everywhere the strata have been curled up to or beyond the vertical, and the thin weak coal beds within deformed carbonaceous shale zones commonly have been squeezed or faulted out by countless structures which cannot be mapped. Thus, even though the coal has been thickened locally or repeated (and spot measurements reveal fractured beds as thick as 3 feet), structural discontinuities render most of it unworkable. Most coal lenses in the isolated pockets are less than 18 inches thick.

Mining and prospecting were attempted in a few places in the Little Trail Creek area. At various times two mines produced a small amount of coal for local domestic use. The Bowers mine was in operation in 1889 and 1890 but not in 1906; the Jones mine was producing in 1906 but not in 1890 . By 1890 the Bowers mine extended 175 feet on an incline of $40^{\circ}-60^{\circ}$ (overturned), and the coal mined then was 2-3 feet thick. The coal had not been mined appreciably on some levels, which suggests that it may not have been of workable thickness everywhere within the mine (Weed, 1891, p. 355, 356; Rowe, 1906, p. 26).

These two mines exploited the only significant pockets of coal exposed at the surface, and most workable coal was extracted before the mines closed. Doubtless, other pockets of structurally isolated and highly deformed coal (generally of at least as good quality as that found in the main Electric field) exist somewhere in the area, though all such coal will be difficult to locate and even more difficult to mine because of the intense and unpredictable structure.

\section{GARDINER AREA}

Drag-zone conditions similar to those just described for the Little Trail Creek area but deeply covered in most places project southeast into the Gardiner area about 4 miles to the park boundary in sec. 24 , T. 9 S., R. 8 E., then continue further southeast into the park to where the Eagle Sandstone is sheared out completely along the Gardiner fault west of Rattlesnake Butte. Gentler dipping and much less deformed Eagle Sandstone crops out along the west face of Mount Everts, but it is not discussed here because it is in the park and cannot be mined. However, it should be noted that the stratigraphic position of coal beds probably changes within the mapped 
area. No well-defined No. 1, 2, or 3 coal bed was found at Mount Everts. (See "Measured Sections," Mount Everts section 4.)

From Little Trail Creek southeast nearly to Gardiner, a distance of about 3 miles, is an area comprising three-fourths of the available coal land in the Gardiner quadrangle. The nearly vertical Eagle Sandstone is covered by Pliocene(?) basalt (0-300 ft thick), travertine (0-40 ft thick), and a thin veneer of glacial till; consequently, little is known about the coal in that area. In addition to the shearing and subsidiary faulting found everywhere in the drag zone, superficial normal faults (described in the section "Structure") are present that disrupt the basalt or travertine in this area. Intelligent prospecting for coal seems out of the question. Mining would be extremely difficult and, because of current instability of the rock, hazardous.

From Gardiner to the park boundary the Eagle Sandstone diverges slightly from the Gardiner fault, is probably a little less deformed, and is very locally exposed. The best coal exposure is on the Jardine road about 0.3 mile above Gardiner. Here the thickest known coal beds east of the Electric field were found. Part of the vertical to slightly overturned section was measured by tape:

Thickness
(feet) (inches)

Impure coal 8. 0

Interbedded mudstone and sandstone 60

Upper coal zone:

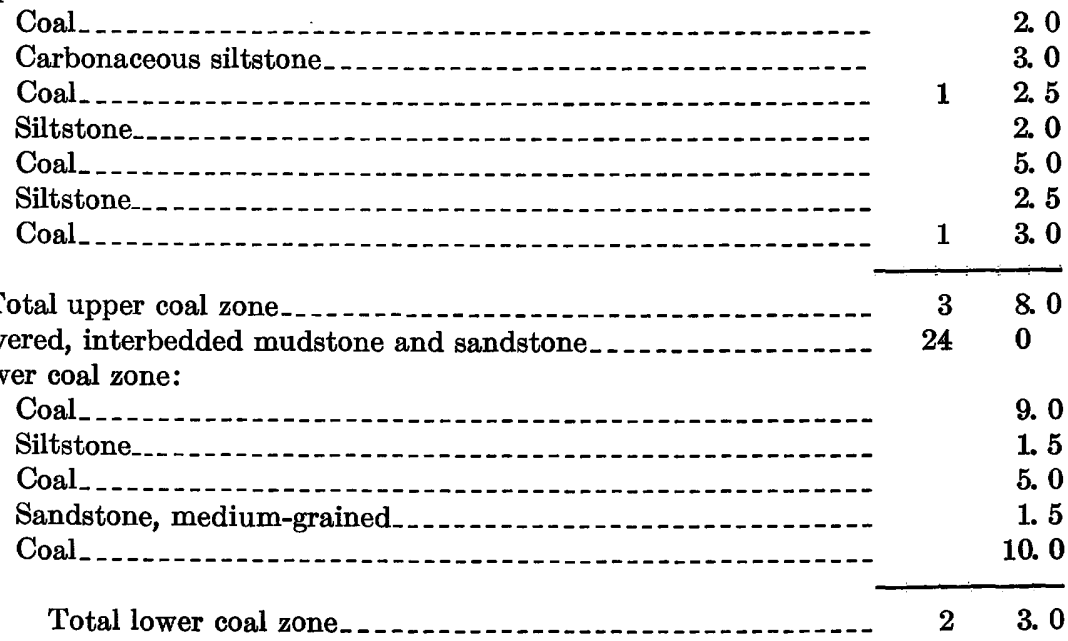
Cover, mudstone and sandstone.

This section is isolated by alluvial cover and travertine and is poorly exposed. It cannot be traced laterally or positioned precisely within the Eagle, nor can it be evaluated for repetition of beds, 
thickening, and thinning. The close spacing of the two thick coal zones suggests structural complications or stratigraphic differences between this section and those measured in the Electric district, the Little Trail Creek area, and Mount Everts. Nevertheless, the exposure does indicate a probability of sizable pockets of coal in parts of secs. 23 and 24 . Isolated exposures of deformed and slumped coal beds of indeterminate thickness and quality were found about half a mile northwest and southeast of the measured partial section. None of the probable coal pockets have been defined as to shape or continuity, and none have been mined. There is evidence of local and somewhat informal prospecting in these areas.

Across the Yellowstone River in the park, the Eagle is still vertical, but thin coal beds near the top of the formation appear fairly continuous.

\section{ECONOMIC POTENTIAL}

Isolated pockets of coal crop out very locally from the vicinity of Gardiner southeast to the Yellowstone River, a distance of about 1 mile. This coal is extractable from surface pits and suitable for local domestic use in times of economic depression or local conditions of poverty but probably is not suitable for commercial production. Mining in these weak vertical beds to any great depth would be extremely hazardous and expensive. There is no assurance that sufficient tonnage could be developed to make such mining profitable. Thicknesses indicated in the partial section above are close to the maximum that can be expected. Much of this land is part of the expanding residential and motel area of the town of Gardiner, which suggests that it will be more valuable unmined than mined. Because of the conditions outlined above, there appears to be no scientific way to estimate coal tonnage and no meaningful way to evaluate or use such estimates should they be made.

\section{OTHER DEPOSITS}

\section{GOLD, ARSENIC, AND TUNGSTEN}

Quaternary placer gold, discovered in 1866 in Bear Creek, and high-temperature Precambrian vein deposits of gold, arsenopyrite, and scheelite, discovered in 1870 at Mineral Hill, have been worked in the Jardine district, which lies partly within the mapped area. More than $\$ 4$ million in gold, about $\$ 485,000$ in arsenic trioxide, and about $\$ 305,000$ in tungsten concentrates had been produced through 1942 (Seager, 1944, p. 1-6). Active mining ceased shortly after World War II when the mill burned; in 1960 and 1961 only small-scale 
prospecting was going on, principally in the Crevice Mountain area southeast of Jardine.

Most of the surface in the part of the Jardine district within the mapped area is covered by glacial deposits, alluvium, colluvium, or timber, and no mines were accessible during the present study. Consequently, no new information was acquired. A detailed report on the district is available (Seager, 1944).

\section{OIL AND GAS PROSPECTS}

The geography of the area limits exploration for oil or gas to the strip, $4 \frac{1}{2}$ miles by 1 mile, of the drag zone of the Gardiner fault. Other sedimentary rock lies in Yellowstone National Park. Because of intense and unpredictable structure (Laramide), local igneous activity (Eocene), renewed movement on the Gardiner fault, and prolonged hot-spring activity (Pleistocene and Holocene), the possibility of finding oil and gas in the drag zone is remote. Faults parallel and transverse to the Gardiner fault have broken the sedimentary rock to the southwest, and erosion in Laramide, Tertiary, and Quaternary time deeply beveled the sedimentary rocks on both sides of the syncline. Igneous rock invaded the sedimentary rock within 2 miles of the Gardiner fault, and large-scale hot springs issue from one of the transverse faults. The area from which hydrocarbons might have migrated into the drag zone is probably only about 10 miles long and 2 miles wide. The presence of dead oil in Permian, Triassic, and Jurassic rocks at Cinnabar Mountain (6 miles northwest of Gardiner) suggests that hydrocarbons migrating into the drag zone escaped in that area. Probably the same thing happened in the Gardiner area, and any residual pools that may remain would be extremely small and could be located only by sheerest chance. This area seems highly unfavorable for the accumulation of oil and gas.

\section{NONMETALLIC DEPOSITS}

Travertine along the Gardiner fault was used for making lime before 1890 (Iddings and Weed, 1894). Quarrying for building stone has been going on for many years and was increasing in 1960 and 1961.

Granite boulders that were deposited by the glaciers in sec. 19, T. 9 S., R. 8 E., have been "quarried" in past years, presumably for tombstones.

Columnar basalt from the bench north of Gardiner was quarried in 1960 and 1961 to provide riprap for a retaining wall to stop an earthflow into the Gardner River in Yellowstone National Park. 
Sand and gravel have been dug, principally from areas along the Yellowstone River, for local use as road metal, aggregate, and building stone.

Phosphate rock, though present in small volume at Cinnabar Mountain, was not found in the Gardiner quadrangle.

\section{GEOLOGIC HISTORY}

Precambrian geologic history is about four times as long as subsequent history and is far from clear. Because of this and because the relationship to subsequent history is even less clear, the Precambrian was discussed previously and only Phanerozoic history is considered here.

Phanerozoic sedimentation began in the Gardiner area in Middle Cambrian time and continued until early Late Cretaceous time, much as it did in nearby parts of Montana and Wyoming, so that formation names from Flathead Sandstone to Eagle Sandstone can be borrowed from other areas and used here with little difficulty. Study of such "normal" sedimentation adds little that is new to the much discussed history of the region, though the dominance of carbonate sedimentation in the Permian may require slight changes to the paleogeography. Volcanoes that contributed bentonite to several pre-Eagle Cretaceous formations must have been located far to the west.

From Cambrian through Triassic time, the area was well out on the stable shelf of the Cordilleran geosyncline. Only about 2,100 feet of pre-Jurassic rock remains in the Gardiner area. Subsequently, in the Rocky Mountain geosyncline, whose axis did pass through the Yellowstone region, perhaps five times as much sediment was deposited in Jurassic and Cretaceous time. However, at no time was the Gardiner area part of a very deep or very deeply buried geosyncline, and a total Paleozoic and Mesozoic stratigraphic thickness of only 9,000-10,000 feet is present in the dropped and almost completely preserved block. The total sedimentary load and the rapidly deposited Cretaceous load both were less than in many other parts of the Rocky Mountains.

From Eagle time onward, conditions at Gardiner were different from those in other areas. The Eagle Sandstone is older (Niobrara) here than in most other parts of Montana, reflecting its known regressive character and a rising landmass to the west. One may postulate that the Laramide orogeny was beginning in nearby areas in Niobrara time. In the Gardiner area, the once-continuous Cretaceous seaway was being choked by continental debris which consisted of intercalated lenses of sand and mud, possibly part of a delta. Probably there 
was more land than water, and fluctuating coal swamps, flood plains, tidal flats, and marine shorelines were common.

Similar conditions prevailed during deposition of the Everts Formation, though by this time nearly all the sea had retreated to the east and most of the coal swamps had dried up. Sedimentary basins 40 miles north and 100 miles south, as well as the one at Gardiner, were each receiving a local and almost exclusively continental deposit that differed in some essential respect from the others. Incipient tectonic compartmentation of the old north-south trough had begun. Still, there is no evidence that a well-defined Beartooth uplift existed or that the Gardiner fault was active. Gentle warping and uplift probably began in this area late in Everts time, for the top of that formation is deeply channeled and overlain by a strikingly different formation.

The Landslide Creek Formation, the last of the Cretaceous units in this area and probably (as originally deposited) the thickest, is wholly continental in origin. Streams from the west or the northwest passed through the area depositing quartz- and chert-rich gravel and dark-colored partly volcanic sand and mud; nearby volcanoes contributed thick layers of light-colored ash, some of which was reworked by the streams; at the west edge of the area channels were cut and filled with thick lenses of andesitic pebbles, cobbles, and boulders, especially near the top of the formation. Though the Beartooth region undoubtedly had risen somewhat, all or nearly all fault movement in the Gardiner area came later. If the Gardiner fault was active, the activity must have been to the northwest, where increasing volcanism also is indicated.

The Laramide orogeny, as approximately defined for this area (p. 62), embraced the long period of time from the end of known Cretaceous deposition to the beginning of known Eocene deposition. Probably at least 20 million years are missing from the stratigraphic record. During this time the entire sedimentary cover and some crystalline Precambrian rock in the upfaulted Beartooth block were removed, and whatever formations were deposited at the same time in the very small negative area to the south were eroded away. Sedimentary beds in the downthrown block were dragged upward along the Gardiner fault to form a narrow asymmetric syncline, and later in Laramide time a transverse graben formed across the syncline. At least 10,000 feet of structural relief developed across the Gardiner fault zone.

The principal result of the orogeny was a pattern of northwestand northeast-trending high-angle faults and a mosaic of differentially uplifted blocks. Sedimentary rocks were saved only in struc- 
turally low areas, mostly in fault troughs and grabens. Evidence for strong lateral compression was not found here, though it has been found in some nearby areas. The major structures were well defined and deeply eroded before Eocene volcanism began, and relatively little differential movement has occurred on the faults since. Because erosion was concurrent with uplift, a local topographic relief in excess of 5,000 feet or an altitude above sea level of more than 5,000 feet, even for the highest Laramide peaks, seems unlikely. The present height above sea level $(5,200-10,500 \mathrm{ft})$ probably results from sporadic epeirogenic uplift, not specifically datable here, that occurred mainly in middle and late Cenozoic time.

Eocene volcanism contributed thousands of cubic miles of dacitic and andesitic breccia to a huge region that now comprises the Gallatin, Beartooth, and Absaroka Ranges and Yellowstone National Park. In the Gardiner area and in many other areas, the airborn pyroclastic debris, volcanic mudflows, fluvially reworked volcanics, and lava flows were deposited on a constantly eroding mountainous surface topographically similar to that of today. In places, including part of the Yellowstone valley, the current valleys are exhumed Eocene valleys. Two early Cenozoic felsic-to-mafic cycles of volcanism have been recognized in the Yellowstone region, but secondcycle volcanics apparently were not deposited in the Gardiner area, and most first-cycle deposits, though erupted from vents in and near the Gardiner area, were removed during Eocene and younger erosion intervals.

Deep middle to late Tertiary erosion is indicated in most parts of the Yellowstone region, and a volcanic hiatus is suggested; but apparent cessation of volcanism may be more the product of subsequent removal and covering of the record than of absolute volcanic quiescence, because nearly all intermontane basins in the Rocky Mountain region, including those adjacent to Yellowstone National Park, contain mid-Tertiary tuff beds. By the time late Cenozoic volcanic deposition began in the Gardiner area with Pliocene(?) basalt flows, an essentially modern drainage pattern not as deeply incised as today's had been established, and only small remnants of the Eocene volcanic pile were left. At least five young basalt flows moved down the Yellowstone valley and through the Gardiner area.

In Pleistocene time a rhyolitic ash-flow sheet moved rapidly into outlying areas from a source in central Yellowstone National Park. Lobes spread northward to bank up on the south side of Sepulcher Mountain and to flow down the Gardner River valley, over Mount 
Everts, and across the Yellowstone valley a short distance up tributary valleys that drain the Beartooth uplift. This Yellowstone Tuff, though mostly welded, is easily eroded. Only small patches remain in the Gardiner area. Later in Pleistocene and perhaps Holocene time, rhyolite and basalt lava flows were deposited in other parts of the park but not at Gardiner.

The northwest end of the Beartooth uplift was reactivated in late Pleistocene time. This flexed and fractured a short segment of the Gardiner fault zone at the west edge of the mapped area. The late uplift can be detected and approximately measured (400 ft) because it displaced the basalt deposited across the fault trace.

The latest events in the Gardiner area include: glaciation, which erased some evidence for Pleistocene faulting, quarried away much basalt in the downthrown block, and left thin deposits of till which indicate that the ice was about 5 miles wide and at least 2,500 feet deep here; hot-spring deposition of travertine along the Gardiner fault zone, which began before some glaciation and continues feebly to this day; incision of the basalt and other rocks mostly by melt water; Holocene earthquakes and minor faulting; landsliding of unstable areas into the newly cut valleys; and continued stream erosion and localized deposition. Thus, geologic history that began perhaps 2.5 billion years ago is still being scribed, very slowly, on the earth's surface, and the Gardiner fault that moved mountains 70 million years ago may still be feebly active.

\section{MEASURED SECTIONS}

A section of Paleozoic and Mesozoic formations from the Amsden through the Frontier was measured 2 miles west of the quadrangle at Cinnabar Mountain to provide stratigraphic information that is not available in the sheared and poorly exposed mapped area. In addition, four separate sections from areas on the northern projection of Mount Everts provide information covering the Upper Cretaceous interval from the upper part of the Telegraph Creek through the Landslide Creek Formations. Finally, three additional partial sections of the Landslide Creek Formation were measured near the west edge of the mapped area to show the variable "western" or coarsely volcanic facies.

A key, table 2, locates each formation in its measured section(s) and summarizes thickness data. 


\section{TABLE 2.-Measured sections and total thicknesses}

[Total thicknesses under $100 \mathrm{ft}$ are rounded to the nearest $5 \mathrm{ft}$; over $100 \mathrm{ft}$, to the nearest $10 \mathrm{ft}$; over 1,000 ft, to the nearest $50 \mathrm{ft}$. Measured thicknesses are rounded to the nearest foot]

\begin{tabular}{llc}
\hline Formation & Measured section & $\begin{array}{c}\text { Thickness (ft) } \\
\text { Measured Total } \\
\text { interval }\end{array}$ \\
\hline
\end{tabular}

Landslide Creek

Eastern facies:

Base.

Western facies:

2,000

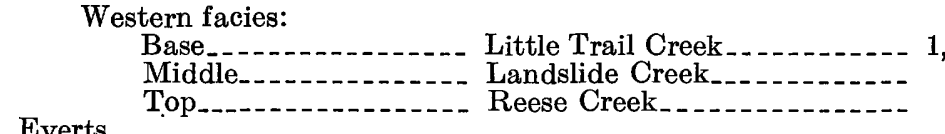

Everts Top._... $372+$

Top

Total

Top missing

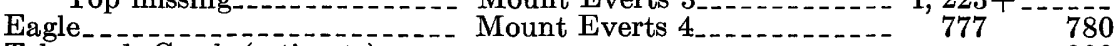

Telegraph Creek (estimate)

Cody
Frontier.

Mowry

Thermopolis.

Cloverly

Morrison_..

Ellis Group

Without basal sandstone.-- From Imlay, Gardner,

Rogers, and Hadley

$$
\text { (1948). }
$$

Basal sandstone

Cinnabar Mountain

Chugwater.

From Newell and Kummel 95

(1942).

Dinwoody

do.

6260

Park City

Phosphoria and Shedhorn..... After Cressman and Swanson $\quad 62 \quad 60$

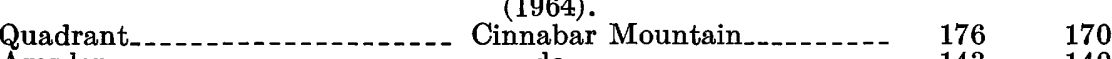

Amsden

Madison... From Wilson $(1934 \bar{b})$ 


\section{Cinnabar Mountain section}

[Sec. 31, T. 8 S., R. 8 E.; top in SW1/4 at abrupt contact with Frontier and Cody Formations near east edge of ridge. As tabulated, section progresses irregularly northeast through Devils Slide. Nearly vertical section measured with tape by G. D. Fraser and H. J. Hyden, June 1960]

Cody Shale.

Frontier Formation:

Upper sandstone member:

144. Sandstone, light-gray (weathers yellowish gray), salt-

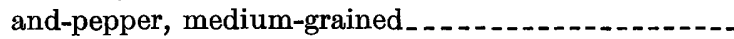

143. Sandstone, like unit 144

Thickness

(feet)

11. 0

20. 0

142. Sandstone, like unit 144

8. 0

141. Shale, black, siliceous; locally contains carbonaceous flecks; interbedded with thin beds of sandstone and siltstone

140. Sandstone, grayish-yellow, salt-and-pepper, mediumgrained with lenses of siliceous shale pebbles, calcareous, locally quartzitic, locally laminated and crossbedded

Total upper sandstone member

Middle shale member:

139. Shale, very dark gray, siliceous; grades downward to

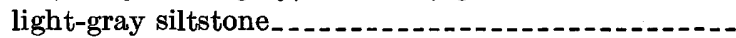

138. Porcellanite, pale-olive

137. Siltstone, fine sandstone, and shale interlaminated, dark-gray

136. Sandstone, dark-gray (weathers brown), fine-grained.-

135. Shale and siltstone interlaminated, dark-gray

134. Sandstone, dark-gray (weathers brown), fine-grained, lenticular

133. Shale, siliceous, and siltstone interlaminated, like

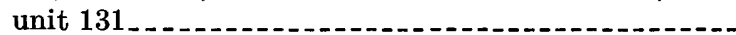

132. Sandstone, fine-grained, quartzitic

131. Shale, siliceous, and siltstone interlaminated; mostly covered; shale is dark gray, siltstone is light gray; both have carbon flecks

3. 0

20. 5

1.5

130. Covered; thin-bedded sandstone and dark-gray shale float

74. 5

64. 0

129. Sandstone, dark-gray, fine-grained, carbonaceous, nodular, irregularly bedded; pinches out in $50 \mathrm{yd}$

128. Covered; mostly dark-gray shale..................

127. Sandstone, light-olive-gray, fine-grained, laminated..--

126. Covered.

125. Shale, black; intercalated with fine-grained thin-bedded siltstone and sandstone; partly covered

71. 0

Total middle shale member 


\section{Cirnabar Mountain section-Continued}

Frontier Formation-Continued

Lower sandstone member:

124. Sandstone, dark-gray, stained dark-reddish-brown, thin and irregularly bedded..................................

123. Sandstone, salt-and-pepper, medium-grained, crossbedded; caps lowest ledge in formation.........

122. Sandstone, medium- to dark-gray (weathers rusty), thin-bedded to laminated; begins low ledge; partly covered.

Total lower sandstone member

55.0

Total Frontier Formation

497. 0

Mowry Shale:

121. Covered

18. 0

120. Shale, black, siliceous

48. 0

119. Sandstone, medium-gray, fine-grained, quartzitic, laminated.

118. Shale, black with rusty stains (some beds weather very light gray), siliceous

117. Covered; mostly black shale

116. Sandstone, light-olive-gray, medium-grained, quartzitic,

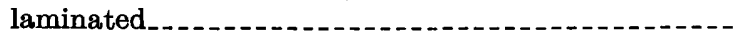

115. Shale, black (weathers with rusty stains), siliceous; locally contains fine sandstone intercalations

114. Sandstone, light-olive-gray, fine-grained, laminated...

113. Covered; siliceous shale and quartzitic sandstone float.-

14. 0

1. 0

186. 0

$$
\text { Total Mowry Shale }
$$

324. 0

Thermopolis Shale (section in downward steps from high on ridge to about $100 \mathrm{ft}$ vertically above valley floor):

Muddy Sandstone Member (measured about one-fourth mile up draw between two sandstone ledges):

112. Sandstone, light-gray, pepper-and-salt, medium-grained; locally coarse grained with chert pebbles as large as half an inch; calcareous; thin bedded; crossbedded; upper $1 \mathrm{ft}$ is quartzitic and rusty; forms conspicuous wall

21. 0

111. Sandstone, light-gray, pepper-and-salt, medium-grained, laminated, nonresistant..............................

110. Covered; mostly thin-bedded sandstone..........-

109. Sandstone, fine-grained, calcareous; weathers grayish brown; contains carbonaceous hash; forms low ledge....

108. Siltstone, medium- to dark-gray (weathers light gray and light brown); grades upward to shale; basal $2 \mathrm{ft}$ is very fine grained sandstone

107. Shale, medium-gray, platy; forms base of gully between upper and lower parts of Muddy 
Cinnabar Mountain section-Continued

Thermopolis Shale-Continued

Muddy Sandstone Member-Continued

Thickness

(feet)

106. Sandstone, like unit 105 but softer

7. 0

105. Sandstone, light-olive-gray, pepper-and-salt, very fine grained, thin and irregularly bedded, crossbedded, ripple-marked; contains local carbonaceous flecks, worm trails, and fossils Ostrea anomioides Meek; grades both ways to less resistant beds

20. 0

Total Muddy Sandstone Member

114. 5

Shale member:

104. Sandstone and lesser shale interbedded, partly covered, slumped; thickness adjusted for slope measurement; like unit 103

20. 0

103. Shale and sandstone interbedded, partly covered, slumped. Sandstone is light olive gray and calcareous, has a pepper-and-salt appearance, contains carbonaceous flecks, and is in 2-in.-to 1-ft-thick wavy crossbedded beds. Worm trails. Adjusted thickness _. -

102. Covered; probably black shale.

26. 0

18. 0

101. Shale, dark-gray to black, interbedded with rare sandstone; about $30 \mathrm{ft}$ from top is $3-\mathrm{ft}$-thick bed of gray to brown fine-grained thin-bedded sandstone.

105. 0

100. Shale, gray to black, intercalated with minor siltstone and fine-grained sandstone.

30. 0

99. Siltstone, gray; contains as much as 50 percent black shale; contains carbonaceous impressions and worm trails.

25. 0

98. Siltstone, dark- to brownish-gray, intercalated with black fissile shale; quartzitic, carbonaceous, resistant; contains worm trails; forms rounded hump ...........-

97. Shale, partly covered, black, fissile, carbonaceous; grades upward into quartzitic siltstone; shows worm trails; contains thin-bedded sandstone in basal $6 \mathrm{ft}$....-

Total shale member

280. 0

Total Thermopolis Shale

394. 0

Cloverly Formation:

Upper sandstone member:

96. Sandstone, light- to medium-gray (weathers rusty), medium-grained, quartzitic, crossbedded, ripplemarked; conspicuously lensing and resistant; abrupt upper contact

95. Shale, black, locally iron stained; intercalated with thin beds and laminae of fine-grained sandstone and siltstone at top.

94. Sandstone, fine-grained, quartzitic; interbedded with 25 percent siltstone and gray to black shale 


\section{Cinnabar Mountain section-Continued}

\section{Cloverly Formation-Continued}

Upper sandstone member-Continued

93. Sandstone, olive-gray (weathers rusty), fine to very fine grained, quartzitic, wavy-bedded............

92. Covered; fine-grained sandstone in upper part .......

91. Sandstone, fine-grained, quartzitic, crossbedded; weathers light olive gray

90. Shale, dark-gray; interbedded with very fine grained

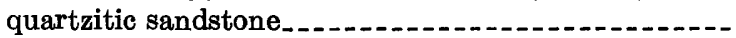

89. Sandstone, yellowish- to brownish-gray, fine-grained, quartzitic; locally contains siltstone laminae, especially at top........

Middle member:

88. Covered; light-gray shale in part._........

87. Limestone, medium-gray (weathers yellowish gray), finely crystalline, dolomitic; contains limestone chips and poorly preserved gastropods and ostracodes, which may indicate top of Kootenai Formation of

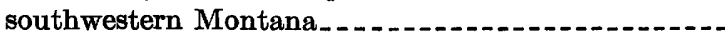

86. Covered.

85. Sandstone, medium- to coarse-grained; contains granules and pebbles; forms ledge stronger than limestone below

84. Covered; mostly gray shale.

83. Limestone, gray, locally limonite stained, dolomitic, shaly, knobby; forms weak ledge................

82. Shale, greenish-gray, calcareous_...................

81. Dolomite, gray (weathers rusty), knobby; grades to calcareous gray shale above.

80. Covered.

79. Limestone, dolomitic, argillaceous, coarsely nodular; matrix is red calcareous shale; contains sparse chert pebbles

78. Shale, grayish-red, mostly covered; contains thin nodular lenses of limestone

77. Limestone, light- to dark-gray, yellow- and red-stained, silty, nodular; grades upward to conglomeratic calcareous sandstone

76. Shale, red._.

75. Mudstone, calcareous; contains limestone nodules and lenses and sparse chert pebbles. . . . . .

74. Covered; contains some red calcareous siltstone and red shale

73. Mudstone, brownish-gray, calcareous; contains limestone nodules.

72. Siltstone, grayish-brown, siliceous; grades upward to calcareous mudstone. 
Cinnabar Mountain section-Continued

Cloverly Formation-Continued

Middle member-Continued

71. Mudstone, grayish-purple, calcareous; contains nodular

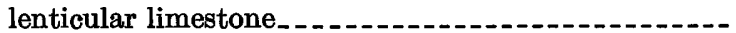

70. Mudstone, light- to dark-gray, limonite-stained; contains nodular lenticular limestone

Total middle member

Lower sandstone and conglomerate member (Pryor(?) Conglomerate Member of Bighorn Basin and south-central Mon$\operatorname{tana):}$

69. Siltstone, light- to dark-olive-gray, siliceous; contains chert pebbles at base

68. Sandstone and siltstone, laminated; forms subordinate ledge; locally channeled by conglomeratic sandstone.-

67. Sandstone; similar to unit 66 but contains fewer and smaller pebbles; forms upper part of conspicuous ledge

66. Sandstone, light- to dark-gray (weathers brown), pepper-and-salt, coarse-grained and conglomeratic in lenses; contains black chert pebbles as large as 3 in., mostly one-half in.; contains channels and crossbeds..-

Total sandstone and conglomerate member

Total Cloverly Formation

360.0

Morrison Formation (top of section near conspicuous brown ledge of Cloverly conglomerate; base about $75 \mathrm{ft}$ vertically above valley floor):

65. Covered

64. Shale, light-gray, siliceous, platy

63. Shale, gray to black, carbonaceous

62. Coal, black to brown, banded, soft, flaky, lignitic....-

61. Sandstone, fine- to medium-grained; weathers yellowish brown; contains carbonaceous flecks.

60. Covered

59. Sandstone, thin-bedded; contains carbonaceous laminae and chips; interbedded with shale; partly covered.--

58. Covered; probably gray shale and some sandstone

57. Sandstone, light- to dark-gray to pale-yellow-brown, medium-grained; contains rare mud and carbonaceous chips; forms weak ledge

56. Covered; mostly shale

30. 0

55. Sandstone, very light gray to pale-yellow-brown (weathers white to light brown), medium-grained, lenticular, crossbedded.

53. Sandstone pale-yellow-brown to light-yellow-gray, fine- to medium-grained, calcareous, crossbedded; contains mud-chip conglomerate in lower half; forms low discontinuous ledge. 


\section{Cinnabar Mountain section-Continued}

\section{Morrison Formation-Continued}

52. Shale, greenish-gray, partly covered

51. Sandstone, yellow-gray (weathers grayish orange), fine- to medium-grained, calcareous, laminated, wavy-bedded, crossbedded; strongest ledge in medial part of formation. . . .

50. Siltstone, red-gray, gray, and green-gray, calcareous;

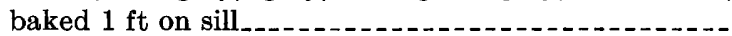

Sill, as below, $5 \mathrm{ft}$, not included.

49. Shale, calcareous, baked, fossiliferous(?)

48. Shale, gray, calcareous, locally baked along 1.5 -ft-thick apophysis from above sill (not included) . .........

47. Siltstone, very light gray (weathers dark yellow orange and brown), calcareous.

46. Shale, gray, partly covered

45. Sandstone, very light gray (weathers yellow gray), very fine grained, calcareous, irregularly laminated .-

44. Shale, variegated, mostly covered; 6-in.-thick very light gray fine-grained microcrossbedded sandstone beds

2. 5

Sill, medium-gray to green, finely crystalline, altered andesite(?); $6 \mathrm{ft}$ (not included).

43. Shale, gray to red variegated; baked $1 \mathrm{ft}$ at top_.....-

42. Siltstone and shale, red-gray, calcareous, fissile to thin-bedded

41. Covered; gray to red siltstone and shale

40. Shale, variegated, blocky to fissile; interbeds as thick as $1 \mathrm{ft}$ of calcareous siltstone and very fine grained sandstone

12. 0

39. Sandstone, light-gray (weathers brown gray), very fine grained, laminated and cross-laminated; lenticular.-

38. Shale, gray-red, light-gray in basal $1 \mathrm{ft}$, fissile; contains laminae and thin beds of gray-brown calcareous siltstone in top half . . .

37. Limestone, light-gray, stained dark-yellow-orange, laminated; shows irregular conchoidal fracture; grades upward to fissile calcareous shale..........-

36. Claystone and shale, variegated, interlaminated with light-gray silty limestone beds from 2 in. to $1 \mathrm{ft}$ thick; contains fossils near base

35. Shale, pale-brown, calcareous, silty, laminated......-

34. Siltstone, gray-yellow-green, calcareous, 1/4-in.-thick beds; contains sparse glauconite from Swift Formation below. 


\section{Cinnabar Mountain section-Continued}

Ellis Group:

Thickness

(feet)

Swift Formation (Imlay and others, 1948)

65. 0

Rierdon Formation (Imlay and others, 1948)

81. 0

Sawtooth Formation (Imlay and others, 1948)

291. 0

Sawtooth Formation (part):

33. Limestone, dark- to light-gray, laminated, sandy,

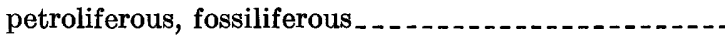

Basal sandstone:

32. Sandstone, brown- and yellow-gray (differentially stained and weathered dark gray), fine- to mediumgrained, calcareous, oil-stained; shows ripple marks; locally nonresistant

6. 5

31. Sandstone, light-gray to light-olive-gray ranging to very dark gray or black owing to dead oil (weathers light brown to dark gray), fine-grained, locally medium grained, very calcareous, locally quartzitic and very fine grained, laminated; laminae grouped in layers from 6 in. to $2 \mathrm{ft}$ thick; petroliferous odor; oil stain conspicuous in basal $10 \mathrm{ft}$; locally veined with calcite; ripples conspicuous in upper $10 \mathrm{ft}$; forms conspicuous ledge

59.5

30. Sandstone, detail from higher in strike gully: lightgray (weathers grayish orange), fine-grained to silty, calcareous, crossbedded; contains scattered dark rounded grains and local lenses of medium- to coarsegrained sandstone; many grains rounded and frosted; weathers down to low, mostly covered shoulder.....

Total basal sandstone.

Total measured Sawtooth Formation

14. 8

80. 8

Total Ellis Group

Chugwater Formation (Newell and Kummel, 1942, p. 995)

Dinwoody Formation (Newell and Kummel, 1942, p. 990-991)

Park City Formation:

Carbonate member:

29. Sandstone and siltstone, thin-bedded; weathers back .

28. Sandstone, brown- to black-stained from dead oil, fineto medium-grained, calcareous; forms weak ledge.

27. Siltstone, gray to brown, dolomitic, platy

26. Limestone, medium-gray (weathers gray brown to light gray), silty, dolomitic; upper 3-4 ft contains abundant nondiagnostic pelecypods; forms conspicuous ledge..

25. Covered

24. Limestone, medium-gray (weathers light brown),

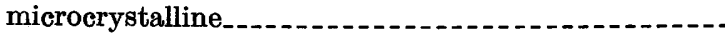

23. Covered_.

22. Limestone, medium-gray (weathers light brown), silty, dolomitic, microcrystalline, vuggy; beds $1-3 \mathrm{ft}$ thick

21. Limestone and dolomite, mostly covered, light-gray; wavy laminations 


\section{Cinnabar Mountain section-Continued}

Park City Formation-Continued

Carbonate member-Continued

20. Limestone, medium-dark-gray (weathers to conspicuous light yellowish brown to reddish brown), thin-bedded.

19. Limestone, light-gray, dolomitic, thin-bedded; weathers easily

18. Dolomite, light-gray to white (weathers brown locally); contains vuggy coarsely crystalline calcareous petroliferous nodules...............

17. Limestone, rubbly, vuggy, cherty, thin to very thin bedded; locally contains dead oil, particularly in basal $1 \mathrm{ft}$

Total carbonate member.

96. 3

Chert, phosphorite, and sandstone; a complex mixture of tongues of Phosphoria Formation and Shedhorn Sandstone (after Cressman and Swanson, 1964, p. 547, excluding 4.8-ft-thick limestone bed at top)

Total Park City Formation

Quadrant Quartzite (measured about $300 \mathrm{ft}$ laterally from valley floor at second level of outcrops; very generalized; dominantly quartzite with differential development of calcareous sandstone; light to dark gray with common yellowish or brownish tints from weathering; dominantly fine grained, locally medium grained; generally massive in appearance but laminae and cross-laminae visible locally):

16. Sandstone and quartzite; forms slope into contact valley with Park City Formation; overlain by reworked bed 1-3 ft thick containing fossil hash and scattered chert pebbles, which was included in Permian

15. Quartzite; forms uppermost conspicuous ridge........-

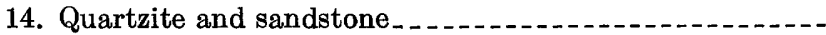

13. Covered; weathers easily

12. Quartzite; contains 1-ft-thick breccia zone at base_..---

11. Sandstone; weathers to small valley; locally very calcareous........................................

10. Sandstone, dolomitic; contains chert nodules ........

9. Dolomite, siliceous; contains limonite-stained chert nodules $3 \mathrm{in.}$ thick and $1 \mathrm{ft}$ long . .

8. Quartzite and sandstone; beds 3-4 ft thick 


\section{Cinnabar Mountain section-Continued}

Amsden Formation (measured $200-300 \mathrm{ft}$ laterally from valley floor in red strike valley; generalized):

7. Dolomite, light-gray; beds 1-6 ft thick

6. Covered

(feet)

39. 0

30.0

5. Dolomite, brown to reddish-gray, silty, finely to coarsely crystalline; beds laminated to $2 \mathrm{ft}$ thick; contains chert locally and 1.5-ft-thick bed of purplish-gray shale

4. Covered...........

3. Dolomite, yellow to pinkish-gray, finely crystalline,

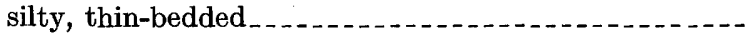

2. Sandstone, light-gray to white, pink- and yellowmottled, medium-grained, calcareous; contains scattered coarse grains; forms ledge ....................

1. Dolomite, limestone, and mudstone interlaminated, differentially pink and gray, thin-bedded; irregular base with $50 \mathrm{ft}$ of relief; limestone or sandstone cobbles as large as 7 in. very locally in pockets

Total Amsden Formation

Madison Limestone:

Limestone, light-gray (locally stained pink), dolomitic, dense to sugary, brecciated, massive; contains black chert especially about $30 \mathrm{ft}$ from top.

\section{Mount Everts section 1}

[Base 0.8 mile east of Eagle Nest Rock. Measured by G. D. Fraser and H. A. Waldrop with Jacob's staff and tape, August 1961]

Landslide Creek Formation (eastern facies, basal part):

Thickness (feet)

53. Sandstone, light-olive-gray to dusky-yellow (weathers dark gray); contains interbedded fine to very coarse grained and conglomeratic lenses; pebbles are as large as 1 in., mostly chert and quartzite; resistant; uppermost exposure on this cliff; not top of formation; more exposed to south.......

52. Mostly covered; conglomeratic sandstone at top; dusky-yellow

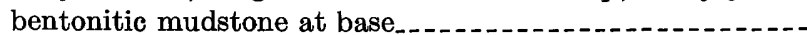

51. Sandstone, medium-olive-gray (weathers dark olive gray), medium-grained; weathers to rounded forms

121. 0

50. Mudstone, dusky-yellow, bentonitic; contains interbedded thin rare medium-grained sandstone.

39. 0

49. Sandstone, olive-gray, medium-grained, cross-laminated; contains rusty mudstone concretions and mud chips near top.

48. Sandstone, olive-gray, iron-stained; conglomeratic at top; silicified; contains mud chips; forms distinctive dark bed.-

47. Mudstone, dusky-yellow, bentonitic; contains medium- to coarse-grained sandstone lenses.

32. 0

Section above measured $200 \mathrm{yd}$ south of top of section below. 


\section{Mount Everts section 1-Continued}

Landslide Creek Formation-Continued

46. Sandstone, dusky-yellow (weathers yellow brown), very fine grained with local medium- to coarse-grained lenses; contains scattered chert pebbles and mud chips; $200 \mathrm{yd}$ south, sandstone is underlain by 4 -ft-thick carbonaceous shale

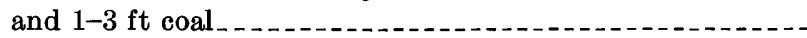

45. Covered; probably dusky-yellow mudstone; thin sparse sandstone beds exposed.

Thickness

(feet)

8. 0

67. 0

44. Sandstone, light-olive-gray, salt-and-pepper, medium-grained, calcareous; cross-laminated in thick to very thick bedded units; contains scattered chert granules and mud chips near top; weathers to rounded form.

43. Mudstone and 25 percent sandstone interbedded; mudstone mostly covered; sandstone is medium gray, salt-and-pepper,

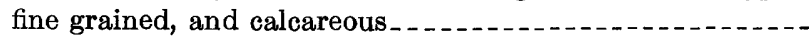

Section above measured 100 yd south of top of section below.

42. Sandstone, pale-yellow-gray (weathers rusty brown), salt-andpepper, fine-grained, calcareous; beds 1-3 ft thick; intercalated with covered mudstone.

41. Sandstone, medium-dark-gray (weathers yellow or brown gray), very fine grained, laminated to thick-bedded, wavybedded; contains shaly intercalations ...................

40. Claystone, nonresistant, partly covered; coarse-grained to conglomeratic sandstone at top; light-gray bentonite at base

39. Mudstone, dark-gray, siliceous; contains siliceous wood fragments.

38. Mudstone, dusky-yellow, bentonitic; contains concretions at top.

37. Sandstone, olive-gray (weathers rusty brown), very fine grained; wavy laminations at base; grades downward ...-

36. Covered; mostly gray to brown carbonaceous shale and claystone... -

35. Sandstone, gray-green (weathers olive gray with rusty stains), very fine grained.

16. 0

34. Mudstone, gray, bentonitic; stained yellow at top; partly covered.

13. 0

19. 0

33. Mudstone, dusky-yellow, bentonitic

32. Sandstone, gray-green, coarse-grained, nonresistant; contains scattered chert granules and pebbles in clay cement; rounded weathering; contains rusty mudstone concretions... -

31. Mudstone, light-olive-gray, bentonitic

30. Sandstone ledges as thick as $3 \mathrm{ft}$ in mudstone matrix, lightolive-gray (weathers brown), fine- to medium-grained...-

6. 2

14. 0

17. 3

Section above measured $100 \mathrm{yd}$ north of top of section below.

29. Coal, black to brown, shaly; includes sandstone laminae and plant fossils. . . .

28. Mudstone, dusky-yellow soil; contains two 1-ft-thick beds of yellow-gray, light-brown-weathering very fine grained sandstone. 


\section{Mount Everts section 1-Continued}

Landslide Creek Formation-Continued

27. Mudstone, dusky-yellow soil; intercalated thin olive-brown sandstone like unit 26.

Thickness (feet)

32. 0

26. Sandstone, olive-brown; medium to very coarse grained with chert granules in clay matrix; nonresistant.

2. 0

6. 5

24. Shale, dusky-yellow, mostly covered; contains three beds 0.5-1.0 ft thick of gray-olive, dark-brown-weathering fine-grained calcareous sandstone that contains mud chips.

23. Sandstone, very light gray to olive or greenish-gray at base (weathers rusty brown), salt-and-pepper, fine- to mediumgrained, calcareous; massive with internal laminae; contains scattered 0.5-in.-thick chert pebbles; includes

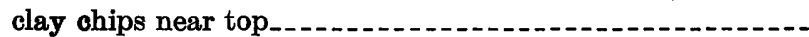

22. Claystone, light-brownish-gray; includes paper carbonaceous shale at top.

21. Sandstone, light-olive-brown, medium to very coarse grained, carbonaceous; clay matrix; contains clay chips as large as 1 in. and twig fossils.

Total measured Landslide Creek Formation.

Erosional unconformity with at least $50 \mathrm{ft}$ of local relief.

Everts Formation (upper part):

20. Covered; mostly light-olive-gray to light-gray claystone

19. Sandstone, light-olive-gray, brown-stained, fine-grained, calcareous

18. Covered; probably claystone...

17. Sandstone, light-olive-gray, brown-stained, fine to very fine grained, thin-bedded to laminated, cross-laminated, very calcareous.

16. Covered; shale and carbonaceous shale, gray to olive-gray and brown

15. Sandstone, light-olive-gray (weathers brown), fine- to

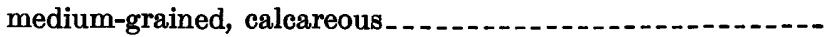

14. Shale and sandstone; shale is carbonaceous and contains plant fossils.

13. Sandstone, light-olive-gray (weathers rusty), very fine grained

12. Shale, olive-gray

11. Sandstone, like unit 13.

10. Claystone.

9. Sandstone, like unit 13

8. Claystone, light-olive-gray

7. Sandstone, like unit 13

6. Claystone, light-olive-gray

5. Mostly sandstone like unit 3 ; includes thin intercalations of claystone

10. 0

1. 2

2.5

1. 8

4. 5

2. 0

.5

2. 5

5. 0

2. 5

6. 0

4. Covered; mostly thin-bedded sandstone and claystone 


\section{Mount Everts section 1-Continued}

Everts Formation (upper part)—Continued

3. Sandstone, light-olive-gray, pepper-and-salt, fine-grained, calcareous; contains scattered heulandite(?) grains; massive units internally cross-laminated...............

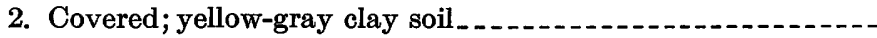

1. Sandstone, light-olive-gray (weathers yellow gray), finegrained, calcareous; contains one resistant unit that has internal lamination.

Total measured Everts Formation

Base covered.

End of Mount Everts section 1.

\section{Mount Everts section 2}

[Base 0.1 mile south of 45th parallel, 0.7 mile east of Gardner River in first gully north of old coal dump, Mammoth quadrangle. Measured by G. D. Fraser and H. J. Hyden with Jacob's staff and tape, August 1960]

Landslide Creek Formation (part):

54. Sandstone, light-gray (weathers brown), medium-grained, locally conglomeratic, crossbedded............

53. Covered; contact with Everts Formation estimated at slope break

Thickness

(feet)

10. 0

103. 0

Total measured Landslide Creek Formation

113. 0

Everts Formation:

52. Covered; contact estimated.

77. 0

51. Sandstone, dark-green-gray (weathers dark olive brown), medium-grained; contains clay chips; color like Landslide Creek Formation but no conglomerate for at least onefourth mile on strike.

8. 0

50. Covered; wooded valley

49. Sandstone, fine- to medium-grained locally, thin-bedded to laminated, wavy-bedded, crossbedded; weathers olive gray; changed dip to $26^{\circ}$

48. Covered; known to contain sandstone lenses

47. Sandstone, light-gray, fine- to medium-grained, thin-bedded to laminated.

10. 0

46. Covered; known to contain sandstone lenses; poor strike and dip control N. $50^{\circ} \mathrm{W} ., 24^{\circ} \mathrm{NE}$

235. 0

45. Sandstone, light-gray, medium-grained, massive, internally cross-laminated; pink and black grains and biotite common; contains shale chips as large as 3 in. in basal $3 \mathrm{ft}$

44. Sandstone and mudstone, mostly covered.......................

43. Sandstone, light-gray, fine-grained, thin-bedded to laminated.

42. Sandstone, lenticular, and mudstone; mostly covered.....--

41. Sandstone, medium-gray (weathers light gray), fine-grained, thin-bedded, crossbedded 


\section{Mount Everts section 2-Continued}

Everts Formation-Continued

40. Covered; thickness doubtful on long dip-slope shot using $\mathrm{N}$. $40^{\circ} \mathrm{W}, 16^{\circ} \mathrm{NE}$

Thickness

(feet)

25. 0

39. Sandstone, light-gray, fine-grained, laminated to mediumbedded; contains black, pink, and green grains; medium lenses and shale chips at base; forms ledge; weathers to rounded forms.

38. Sandstone, light-gray, fine-grained, irregularly bedded, nonresistant; contains gray shale chips as large as 1 in.....--

37. Sandstone, light-gray (weathers yellow to brown gray), very fine grained

36. Mudstone, light-gray where dry

35. Sandstone, light-gray, fine-grained, cross-laminated.........

34. Covered; probably lenticular sandstone and mudstone....-.

33. Sandstone, light-gray, pepper-and-salt, medium-grained; contains siltstone pebbles as large as 2 in.; laminated and cross-laminated in units as thick as $1 \mathrm{ft}$; differential cement. . . . - . - .

32. Covered; probably friable sandstone and mudstone.......-

31. Sandstone, light-gray, fine- to medium-grained; contains abundant black grains and scattered pink and green grains; cross-laminated in units as thick as $1 \mathrm{ft}$

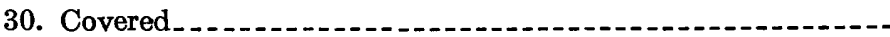

29. Sandstone, light-gray (weathers olive gray or dusky yellow),

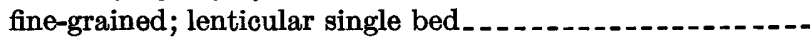

28. Covered.

27. Sandstone, light-gray, medium-grained, friable; contains abundant black grains and scattered pink and green grains

13. 5

12. 0

3. 0

27. 0

1. 0

24. 0

2. 0

26. Mudstone, gray, mostly covered; interbedded with cross-laminated lenticular sandstone

15. 0

25. Sandstone, light-gray, fine-grained; cross-laminated within beds 2-3 ft thick . . . . . .

Beds above sill measured 200 yd south of top of section below. Sill, hornblende andesite; hornblende as long as one-half in.; 60

ft thick (not included).

24. Mudstone and lenticular sandstone, mostly covered.......

23. Sandstone, light-gray, fine-grained, lami nated...........

22. Covered; probably mudstone.............

21. Sandstone, light-gray, salt-and-pepper, fine-grained, crosslaminated

20. Mudstone, covered; contains lenticular sandstone beds as thick as $1 \mathrm{ft}$

19. Sandstone, gray (weathers olive gray and brown), very fine grained

68. 0

1.3

10. 0

3. 5

17. 0

.8

3. 0

4. 0

22. 0

2. 0

3. 0

15. Sandstone, gray (weathers olive to brown), very fine grained.

14. Claystone, gray 


\section{Mount Everts section 2-Continued}

Everts Formation-Continued

13. Sandstone, medium-gray (weathers olive gray to brown), fine-grained.

12. Claystone, green and gray

11. Sandstone, light-gray, fine-grained, thin-bedded to laminated

10. Covered; mudstone

9. Siltstone, medium-gray (weathers brown gray), crosslaminated.

8. Covered; mudstone

7. Sandstone, gray-green, fine-grained, laminated

6. Covered; gray mudstone

Thickness (feet)

1. 8

5. 7

3. 5

15. 0

1. 0

9. 5

1. 0

3. 0

Total Everts Formation (only approximate because of uncertain dip in many areas and thick cover at top of formation)

Eagle Sandstone (top part only; strike N. $40^{\circ}$ W., dip $15^{\circ}$ NE.; top of Eagle Sandstone picked at top of first sandstone above last coal) :

5. Sandstone, light-gray, pepper-and-salt, fine to very fine grained, thin-bedded.

4. Covered; mudstone and fine-grained sandstone.

3. Sandstone, medium-gray (weathers light gray to rusty brown), pepper-and-salt, fine-grained, cross-laminated._...-.

2. Shale, gray to brown, locally carbonaceous, fissile

1. Coal, black, fractured.

Total measured Eagle Sandstone

End of Mount Everts section 2.

\section{Mount Everts section 3}

[Top about 0.3 mile south of island in the Yellowstone River on projected range line 8-9 E. Top faulted, base covered; but nearly the whole Everts Formation thickness is represented; nearly vertical beds. Measured by G. D. Fraser and H. A. Waldrop with tape, August 1961]

\section{Everts Formation:}

23. Claystone, yellow-gray, interbedded with calcareous yellowgray siltstone.

22. Sandstone, light-olive-gray, very fine grained, laminated.-

21. Sandstone and claystone interbedded; sandstone like unit 22 in beds as thick as $2 \mathrm{ft}$

13. 0

20. Claystone, medium-gray to light-olive-gray; locally includes very thin coal, carbonaceous shale, and siltstone lenses_--

19. Sandstone, pale-olive, fine-grained, calcareous; contains Corbula sp. coquina.

18. Limestone, medium-dark-gray; stained dusky-yellow and moderate-yellow-brown; shaly

1.5

17. Claystone, siltstone, and sandstone interbedded; sandstone is yellow gray to light olive gray, fine grained, and calcareous. 
Mount Everts section 3-Continued

Everts Formation-Continued

Thicknes8

( feet)

16. Covered...

29. 5

15. Sandstone and claystone interbedded; sandstone is yellow gray (weathers light yellow brown to dusky yellow) and very fine grained and forms serrate cross-laminated vertical ridges as thick as $5 \mathrm{ft}$; claystone is medium dark gray to yellow gray; Corbula sp. zone about $50 \mathrm{ft}$ from top......-

14. Claystone, mostly covered; interbedded with sandstone like unit 15; claystone dominant..........

13. Sandstone, light-gray, salt-and-pepper, fine- to mediumgrained, calcareous; cross-laminated but weathers to rounded ledges that elsewhere form conspicuous bluff; discontinuous ledges indicate lenticular sandstone........-

Offset westerly along strike.

12. Sandstone, like unit 13; lower $50 \mathrm{ft}$ slightly less resistant, partly covered; contains a few beds of dusky-yellow sandstone and probably claystone in covered intervals; contains limestone concretions as large as $1 \mathrm{ft}$

140. 0

87. 0

25. 0

131. 0

113. 0

10. Sandstone, light-olive-gray (weathers yellow gray), saltand-pepper, fine-grained, calcareous, thin-bedded, crossbedded; contains biotite; probably one of many sandstones intercalated with claystone on this slope

3. 0

9. Covered; contains sandstones and claystones

345. 0

8. Sandstone, light-gray, pepper-and-salt, fine-grained, calcareous, lenticular, thin-bedded, crossbedded; contains biotite and hornblende.

7. Covered; contains several beds of laminated calcareous siltstone, claystone, and fine-grained sandstone

6. Sandstone, yellow-gray (weathers yellow to brown gray), finegrained, calcareous, thin-bedded, crossbedded...........

5. Covered

50. 0

2. 8

18. 5

4. Sandstone, like unit 6 but very fine grained.......

3. Claystone, sandstone, siltstone, and carbonaceous claystone interbedded; sandstone is like unit 6 and in lenticular layers $0.5-3 \mathrm{ft}$ thick; claystone dominant

43. 0

2. Sandstone, pepper-and-salt, fine-grained, carbonaceous, friable, calcareous, thin-bedded, crossbedded, lenticular; fossiliferous at base, includes Ostrea sp., Cymbophora sp. of. $C$. utahensis Meek. .

1. Covered; base of formation arbitrary 140.0

Total measured Everts Formation 


\section{Mount Everts section 4}

1.3 miles NNE. of Mammoth, Wyo., on west slope of Mount Everts, $44^{\circ} 59^{\prime} 30^{\prime \prime} \mathrm{N} ., 110^{\circ} 41^{\prime} 00^{\prime \prime}$ W. Measured by G. D. Fraser and H. A. Waldrop with tape and Jacob's staff, August 1961]

Everts Formation (base only):

68. Shale, mostly gray, locally slightly carbonaceous, mostly covered

Thickness

(feet)

17. 0

Contact placed at top of sandstone just above last coal.

Eagle Sandstone:

Coal member:

67. Sandstone, yellowish-gray (weathers yellowish to brownish gray), fine-grained, calcareous, cross-laminated, thick to very thick bedded; forms conspicuous bluff.-

19. 0

66. Shale, dark-brown, carbonaceous; local black coal.-...--

65. Covered

64. Sandstone, light-gray (weathers yellowish gray), fineto medium-grained, calcareous, cross-laminated, thickbedded

63. Covered

62. Sandstone, light-gray (weathers brownish gray), finegrained, calcareous, thin-bedded.

61. Covered

60. Sandstone, light-gray (weathers brownish to yellowish gray), fine-grained, calcareous, thin-bedded, irregularly bedded.

59. Mostly shale, dark-gray; contains minor light-gray sandstone interbeds 1-2 ft thick and at top a nodular limestone bed 0-18 in. thick

58. Sandstone, light-gray (weathers yellowish to brownish gray), fine-grained, calcareous, crossbedded, thickbedded.

57. Covered; mostly shale; some carbonaceous shale that contains very thin slumped coal seams; contains rare thin sandstone beds.

56. Sandstone, light-gray (weathers yellow gray), fine-grained, calcareous, thick-bedded.

55. Shale, partly covered, light- to dark-gray and brown, locally carbonaceous; contains some thin coal seams.-

54. Sandstone, light-gray (weathers yellow to orange gray), fine-grained, calcareous, thin- to thick-bedded.....

53. Shale, carbonaceous and noncarbonaceous, partly covered; contains sandstone lenses 1-2 ft thick...-

52. Coal, black, slumped

51. Sandstone, thin- to thick-bedded, nonresistant; intercalated with thin shale beds. ......................

50. Sandstone, medium-gray (weathers yellowish gray), finegrained, calcareous; contains carbonaceous debris...--

49. Covered. . . .

48. Limestone, medium-dark-gray, concretionary, lenticular; not persistent laterally; stained grayish orange......-

47. Sandstone, thin-bedded, nonresistant; intercalated with thin shale beds

46. Shale, carbonaceous, and thin sandstone beds; partly covered 


\section{Mount Everts section 4-Continued}

Eagle Sandstone-Continued

Coal member-Continued

45. Sandstone, thin-bedded, shaly; intercalates downward with carbonaceous shale.

Thickness

(feet)

44. Shale, carbonaceous; partly covered; contains at least two slumped coaly beds and small lenses of sandstone_

27. 0

43. Sandstone, medium-light-gray, very fine grained, noncalcareous, siliceous, thin-bedded; stained moderate reddish orange on joint and bedding surfaces

42. Sandstone, pale-yellow-brown (weathers light brown), calcareous, thin- to medium-bedded; has wavy laminae; contains plant fossils at top.

41. Covered; nonresistant sandstone and carbonaceous shale

40. Sandstone, medium-gray (weathers yellowish gray), fine-grained, calcareous, thick-bedded..............

39. Covered; mostly carbonaceous shale

38. Coal, shaly

37. Shale, carbonaceous, mostly covered.

36. Sandstone, shaly, carbonaceous

35. Sandstone, light-gray (weathers yellow gray to yellow brown), fine-grained, calcareous, cross-laminated, very thick bedded; forms bluff, but only locally resistant; changes laterally to nonresistant slabby laminated sandstone

34. Sandstone, thin-bedded, friable, mostly covered.......-

33. Sandstone, light-gray (weathers yellowish gray), finegrained, calcareous, very thick bedded.........-.

32. Mostly covered; intercalated carbonaceous shale and thin-bedded laminated sandstone

31. Mostly covered; carbonaceous shale; has coaly zone at base

30. Sandstone, pale-yellow-brown, fine-grained, calcareous, ripple-laminated, thin- to thick-bedded; forms small ledge.

19. 0

3. 0

29. Covered.

28. Shale, carbonaceous.

27. Covered.

26. Shale, carbonaceous.

2. 0

21. 0

2. 0

25. Covered

18. 0

24. Sandstone, yellowish-gray (weathers light brown), calcareous, cross-laminated, thin- to thick-bedded....-.

23. Covered; probably carbonaceous shale.

18. 5

20. 0

22. Sandstone, medium-light-gray, fine-grained, calcareous, ripple-laminated

4. 0

12. 0

2. 0

1.5

20. Carbonaceous shale, partly covered

19. Coal, black, crumbly, slumped; thickness is uncertain

18. Covered; probably thin-bedded sandstone grading upward to carbonaceous shale

19. 0

Total coal member 


\section{Mount Everts section 4-Continued}

Eagle Sandstone-Continued

Virgelle Sandstone Member:

17. Sandstone, light-gray, fine- to medium-grained, calcareous, friable, thin-bedded to laminated; stained dark yellowish orange at bottom and top; mostly covered and weathers to gentle slope here but forms top of bluff $50 \mathrm{yd}$ to south........

16. Sandstone, arkosic, same as unit 15; contains fewer coarse lenses and no chert pebbles; top $10 \mathrm{ft}$ weathers easily.

Thickness
$($ feet $)$

16. 5

26. 0

15. Sandstone, same as unit 14 , but contains thin lenses of very coarse grained sandstone and scattered chert granules and very rare pebbles_.

14. Sandstone, light-gray (weathers yellow to brownish gray), fine- to medium-grained, calcareous, crosslaminated; contains biotite flakes; forms bluff; weathers to rounded forms

13. Sandstone, medium-light-gray, salt-and-pepper, calcareous, cross-laminated, platy, nonresistant; partly covered slope; separates lower and upper bluffs of

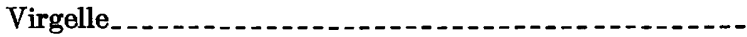

12. Sandstone, medium-light-gray (weathers light olive gray), salt-and-pepper, fine-grained, calcareous; has high-angle cross-laminae; massive, becomes thinner bedded at top; forms bluff

11. Sandstone, like unit 12 but weathers slabbier to 3 -in.thick composite beds; gradational contact with Telegraph Creek Formation. . . .

Total Virgelle Sandstone Member. 163. 0

Total Eagle Sandstone

777. 0

Telegraph Creek Formation (top part only):

10. Covered slope

16. 6

9. Sandstone, medium-light-gray (weathers brownish gray), fine-grained, calcareous; has laminae 3-10 mm thick that weather to wavy plates

8. Sandstone, medium-light-gray (weathers yellowish gray), fine-grained, laminated, calcareous...............

7. Covered.

6. Sandstone, light-gray (weathers pale yellowish gray), fine to very fine grained; has irregular laminae that weather to curving plates_.......... 28. 0

5. Covered; friable thin- to thick-bedded sandstone and
shale

5. Covered; friable thin- to thick-bedded sandstone and
shale

1. 9

3. 1

4. Sandstone, light-gray, salt-and-pepper, fine-grained, calcareous; cross-laminated in thick composite bed........

3. Covered slope 


\section{Mount Everts section 4-Continued}

Telegraph Creek Formation (top part only)-Continued

Beds above form grassy slope with sandstone in weak ledges; strike N. $55^{\circ}$ W., dip $21^{\circ} \mathrm{NE}$.

2. Sandstone, medium-light-gray (weathers yellow gray with rusty stains), salt-and-pepper, fine to very fine grained, calcareous; laminated within thin to very thick beds; contains sparse shale laminae; forms steep bluff.

1. Sandstone, siltstone, and shale interbedded; forms steep well-exposed slope; sandstone, some that contains microcrossbeds, dominant in laminated and unlaminated units as thick as $1 \mathrm{ft}$; shale, in units as thick as $0.5 \mathrm{ft}$; whole sequence light to dark gray, calcareous, weathers differentially; strike N. $55^{\circ}$ W., dip $18^{\circ} \mathrm{NE}$.-

Total measured Telegraph Creek Formation

Base covered.

End of Mount Everts section 4.

\section{Little Trail Creek section}

[NE1/4 sec. 8, T. 9 S., R. 8 E., Miner quadrangle, between U.S. Highway 89 and Little Trail Creek; beds overturned. Measured by G. D. Fraser and H. A. Waldrop with tape, August 1961]

Top covered.

Landslide Creek Formation (western facies, basal part):

32. Sandstone, light-olive-gray (weathers moderate brown), medium-grained; contains scattered chert pebbles and conglomerate lenses as much as 6 in. thick; forms lenticular ridge

31. Covered; yellow-gray soil

30. Sandstone, yellow-gray (weathers moderate brown), medium to very coarse grained; includes chert, andesite, quartzite granules, and rare pebbles; forms small ledge

29. Covered; yellow-gray soil

28. Sandstone, like unit 30

Beds below measured 50 yd SE of beds above.

27. Sandstone, similar to unit 30 but more coarsely conglomeratic and less resistant

24. 0

26. Conglomerate and sandstone, light-olive-gray (weathers brown gray); common granules and pebbles, less common cobbles as large as 5 in., upper $10 \mathrm{ft}$ not as coarse; andesite common, heulandite sparse; contains carbonaceous plant debris and rare dinosaur-bone fragments; forms conspicuous dark lens $50 \mathrm{yd}$ long on strike.

25. Claystone, light-olive-brown to pale-olive, bentonitic; partly covered.

24. Sandstone, pale-olive (weathers brown gray), fine- to mediumgrained, thin-bedded; contains biotite 


\section{Little Trail Creek section-Continued}

Landslide Creek Formation (western facies, basal part)-Continued

23. Covered; probably bentonitic claystone

Thickness

(feet)

28. 0

22. Sandstone and bentonitic claystone interbedded; sandstone is dusky yellow green, medium to coarse grained, and locally conglomeratic

34. 0

21. Claystone, sandstone, and siliceous mudstone interbedded; claystones are bentonitic; sandstones are conglomeratic; some siliceous mudstones have heulandite on joint faces...-

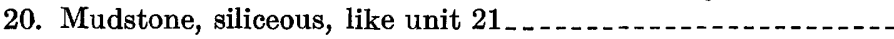

19. Claystone, bentonitic; contains brown carbonaceous layers and lenticular sandstone; mostly covered

18. Sandstone, dusky-yellow (weathers moderate brown), medium-grained

17. Covered; probably bentonitic claystone.

89. 0

21. 0

1. 5

59. 0

16. Sandstone, light-olive-gray (weathers grayish orange to dark yellow brown), thin- to thick-bedded, crossbedded, medium to very coarse grained; locally conglomeratic with chert, quartzite, and altered andesite pebbles as large as 3 in.; forms lenticular ridge.

51. 0

15. Claystone and sandstone interbedded, partly covered; contains local heulandite

14. Claystone, bentonitic; dusky-yellow covered zone $\ldots . . . . .$.

13. Sandstone, yellow-gray (weathers brownish gray), mediumgrained, thin- to thick-bedded, crossbedded; forms small lenticular ledge.

12. Bentonite, dusky-yellow; mostly covered.

4. 5

25. 0

11. Sandstone, like unit 13, locally coarse and conglomeratic; contains plant fossils and mud chips.

6. 5

10. Bentonite and bentonitic claystone, dusky-yellow and paleolive; mostly covered; thin lenticular sandstone at top.-.-

9. Bentonite, bentonitic mudstone, siliceous mudstone, and thin lenticular sandstone; largely covered and slumped.

11. 0

34. 0

69. 0

50. 0

8. Sandstone, yellow-gray (weathers dusky yellow to moderate brown), fine- to coarse-grained, thin- to thick-bedded, crossbedded, lenticular

7. Bentonite and claystone, yellow to brown; partly covered.--

6. Conglomerate; forms prominent dark-colored lenticular ridge for $300 \mathrm{ft}$ on strike; rich in andesitic boulders as large as $1 \mathrm{ft}$.

5. Covered; probably bentonitic claystone

4. Sandstone, yellow-gray (weathers brown gray), medium to very coarse grained and locally conglomeratic with mostly chert pebbles; crossbedded; forms low ridge. . . . . . . -

3. Covered

2. Sandstone, like unit 4

1. Covered.

28. 0

50. 0

60. 0

55.0

27. 0

230. 0

Total measured Landslide Creek Formation 


\section{Landslide Creek section}

[East of Landslide Creek, sec. 21, T. 9 S., R. 8 E., at west edge of Gardiner quadrangle. Measured by G. D. Fraser and H. A. Waldrop with Jacob's staff, August 1961]

Landslide Creek Formation (western facies, middle(?) part):

Top covered; st rike N. $85^{\circ}$ W., dip $25^{\circ} \mathrm{NE}$.

14. Sandstone, light-olive-gray (weathers gray brown to dark yellow brown), medium to very coarse grained, carbonaceous; forms small rounded ridge; interbedded with porcellanite and bentonitic claystone which dominate upper $10 \mathrm{ft}$

Thickness

( $f e e t)$

45. 0

13. Covered; sandstone, porcellanite, bentonite float

197. 0

12. Covered; trachybasalt unconformably above Landslide Creek Formation; typical Landslide Creek Formation float begins near top with white porcellanite and sandstone; thickness applies to Landsli de Creek Formation . . . . . . . . . . . . .

11. Covered; trachybasalt like unit 12 ; fills channel in sedimentary rock

130. 0

70. 0

10. Sandstone, like unit 8; forms low ridge between two higher and thicker ridges along strike

20. 0

9. Covered; sandstone float; much of interval is sandstone ridge on strike; sandstones lenticular or differentially resistant or both

60. 0

8. Sandstone, pale-olive (weathers moderate yellow brown), coarse-grained to conglomeratic, thin to very thick bedded, crossbedded; pebbles, some angular, include yellow-gray tuff and reddish-brown hornblende and biotite andesite...

7. Covered

6. Porcellanite, white; mostly covered and probably interbedded with sandstone.

5. Covered; sandstone float

4. Sandstone, mostly covered; forms rounded ridge with jostled sandstone blocks like unit 2 .

3. Covered; bentonitic soil in part . .

2. Sandstone, yellow-gray (weathers gray brown); contains coarse to very coarse grained granules of feldspar, biotite, and volcanic rock; mostly covered; forms low ridge

1. Covered; float is white porcellanite and fine to coarse grained sandstone

Total measured Landslide Creek Formation.

End of Landslide Creek section. 


\section{Reese Creek section}

[SE1/4 sec. 7, T. 9 S., R. 8 E., Miner quadrangle. Measured by G. D. Fraser and H. A. Waldrop with Jacob's staff ,August 1961]

Dacitic breccia:

Tuff breccia and tuff, generally light gray; contains angular clasts of Precambrian schist and gneiss; locally in this area large blocks and boulders of Precambrian rock at base; contact poorly exposed where underlying rocks measured.

Angular unconformity.

Landslide Creek Formation (western facies, top only):

Thickness (feet)

10. 0

85. 0

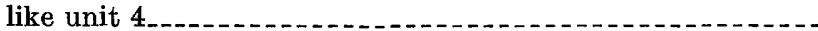

4. Sandstone and conglomerate interbedded, variegated, lightolive-gray speckled with abundant pale-red heulandite, medium to very thick bedded, friable, channeled; contains abundant andesitic pebbles and cobbles; forms weak bluff.-

3. Covered; some friable sandstone and conglomerate like unit 1.

2. Sandstone, like unit 1 , mostly coarse to very coarse grained, differentially friable; contains conglomerate lenses as thick as $5 \mathrm{ft}$ and abundant heulandite

1. Sandstone, medium-light-gray (weathers light olive gray), salt-and-pepper, medium-grained to conglomeratic, laminated to thick-bedded, crossbedded; contains conglomerate lenses as thick as $3 \mathrm{ft}$, cobbles as large as 3 in.; biotite on bedding planes; heulandite abundant; dominantly of andesitic composition

Total measured Landslide Creek Formation

372.0

Base covered.

End of Reese Creek section.

\section{REFERENCES CITED}

Alden, W. C., 1932, Physiography and glacial geology of eastern Montana and adjacent areas: U.S. Geol. Survey Prof. Paper 174, 133 p.

Allen, E. T., and Day, A. L, 1935, Hot springs of the Yellowstone National Park: Carnegie Inst. Washington Pub. 466, 525 p.

Anderson, C. A., 1933, Tuscan formation of northern California, with a discussion concerning the origin of volcanic breccias : California Univ. Dept. Geol. Sci. Bull., v. 23, no. 7, p. 215-276.

Bauer, C. M., 1948, Yellowstone, its underworld : geology and historical anecdotes of our oldest National Park: Albuquerque, New Mexico Univ. Press, 122 p.

Bengtson, C. A., 1956, Structural geology of the Buffalo Fork area, northwestern Wyoming, and its relation to the regional tectonic setting, in Wyoming Geol. Assoc. Guidebook 11th Ann. Field Conf., Jackson Hole, 1956: p. 158-168.

Berg, R. R., 1962, Mountain flank thrusting in Rocky Mountain foreland, Wyoming and Colorado: Am. Assoc. Petroleum Geologists Bull., v. 46, no. 11, p. 2019-2032.

Boyd, F. R., 1961, Welded tuffs and flows in the rhyolite plateau of Yellowstone Park, Wyoming: Geol. Soc. America Bull., v. 72, no. 3, p. 387-426. 
Brown, O. W., 1957, Stratigraphic and structural geology of north-centralnortheast Yellowstone National Park, Wyoming and Montana: Princeton Univ. Ph. D. thesis; available from Univ. Microfilms, Inc., Ann Arbor, Mich. $176 \mathrm{p}$.

1961, Cenozoic stratigraphy and structural geology, northeast Yellowstone National Park, Wyoming and Montana: Geol. Soc. America Bull., v. 72, no. 8, p. 1173-1193.

Bush, J. H., 1967, Basalts of the Yellowstone valley, southwestern Montana [abs.] : Geol. Soc. America, Rocky Mtn. section, 20th Ann. Meeting, Golden, Colo., May 10-14, 1967, p. 25-26.

Calvert, W. R., 1912, The Electric coal field, Park County, Montana : U.S. Geol. Survey Bull. 471-E, p. 406-422.

Cohee, G. V., chm., and others, 1961, Tectonic map of the United States, exclusive of Alaska and Hawaii: U.S. Geol. Survey and Am. Assoc. Petroleum Geologists [1962].

Combo, J. X., Brown, D. M., Pulver, H. F., and Taylor, D. A., 1949, Coal resources of Montana : U.S. Geol. Survey Circ. 53, $28 \mathrm{p}$.

Condit, D. D., 1918, Relations of late Paleozoic and early Mesozoic formations of southwestern Montana and adjacent parts of Wyoming: U.S. Geol. Survey Prof. Paper 120-F, p. 111-121.

Cressman, W. R., and Swanson, R. W., 1964, Stratigraphy and petrology of the Permian rocks of southwestern Montana: U.S. Geol. Survey Prof. Paper 313-C, p. 275-569.

Curtis, G. H., 1954, Mode of origin of pyroclastic debris in the Mehrten formation of the Sierra Nevada: Calif. Univ. Pubs. Geol. Sci., v. 29, no. 9, p. 453-502.

Daly, R. A., 1933, Igneous rocks and the depths of the earth: New York, McGraw-Hill Book Co., $508 \mathrm{p}$.

Dorf, Erling, 1960, Tertiary fossil forests of Yellowstone National Park, Wyoming, in Billings Geol. Soc. Guidebook 11th Ann. Field Conf., West Yellowstone-Earthquake area, 1960 : p. 253-260.

Fenneman, N. M., and Johnson, D. W., 1946, Physical divisions of the United States : U.S. Geol. Survey map.

Foose, R. M., Wise, D. U., and Garbarini, G. S., 1961, Structural geology of the Beartooth Mountains, Montana and Wyoming: Geol. Soc. America Bull., v. 72, no. 8, p. 1143-1172.

Fox, S. K., Jr., 1939, The stratigraphy and micropaleontology of the Cody shale in southern Montana and northern Wyoming : Princeton Univ. Ph. D. thesis; available from Univ. Microfilms, Inc., Ann Arbor, Mich., 195 p.

Fraser, G. D., Witkind, I. J., and Nelson, W. H., 1964, A geological interpretation of the epicentral area-the dual basin concept: U.S. Geol. Survey Prof. Paper 435-J, p. 99-106.

Fyfe, W. S., Turner, F. J., and Verhoogen, John, 1958, Metamorphic reactions and metamorphic facies: Geol. Soc. America Mem. 73, 259 p.

Gardner, L. S., Hendricks, T. A., Hadley, H. D., and Rogers, C. P., Jr., 1945, Mesozoic and Paleozoic rocks in the mountains of south-central Montana : U.S. Geol. Survey Oil and Gas Inv. Prelim. Chart 18.

- 1946, Stratigraphic sections of Upper Paleozoic and Mesozoic rocks in south-central Montana: Montana Bur. Mines and Geology Mem. 24, $100 \mathrm{p}$.

Good, J. M., 1965, Prehistoric landslide in Yankee Jim Canyon, Park County, Montana [abs.] : Geol. Soc. America Spec. Paper 82, p. 327-328.

Hadley, J. R., 1964, Landslides and related phenomena accompanying the Hebgen Lake earthquake of August 17, 1959: U.S. Geol. Survey Prof. Paper 435-K, p. 107-138. 
Hague, Arnold, 1904, Atlas to accompany Mon. 32 on the Geology of the Yellowstone National Park : U.S. Geol. Survey Mon. 32.

Hague, Arnold, Weed, W. H., and Iddings, J. P., 1896, Yellowstone National Park, Wyoming: U.S. Geol. Survey Geol. Atlas, Folio 30.

Hague, Arnold, and others, 1899, Geology of the Yellowstone National Park: U.S. Geol. Survey Mon. 32, pt. 2, 893 p.

Hall, W. B., 1959, Multiple glaciation and high-level till deposits in southwestern Montana [abs.] : Geol. Soc. America Bull., v. 70, no. 12, pt. 2, p. 1778.

Hamilton, Warren, and Leopold, E. B., 1963, Volcanic rocks of Oligocene age in the southern part of the Madison Range, Montana and Idaho, in Short papers in geology, hydrology, and topography: U.S. Geol. Survey Prof. Paper 450-B, p. B26-B29.

Horberg, C. L., 1940, Geomorphic problems and glacial geology of the Yellowstone Valley, Park County, Montana: Jour. Geology, v. 48, no. 3, p. 275-303.

Horn, G. H., 1963, Geology of the East Thermopolis area, Hot Springs and Washakie Counties, Wyoming: U.S. Geol. Survey Oil and Gas Inv. Map OM-213.

Howard, A. D., 1937, History of the Grand Canyon of the Yellowstone: Geol. Soc. America Spec. Paper 6, 159 p.

Howard, J. H., 1966, Structural development of the Williams Range thrust, Colorado: Geol. Soc. America Bull., v. 77, no. 11, p. 1247-1263.

Iddings, J. P., 1904, A fracture valley system [Montana] : Jour. Geology, v. 12, p. $94-105$.

Iddings, J. P., and Weed, W. H., 1894, Livingston atlas sheet [Montana] : U.S. Geol. Survey Geol. Atlas, Folio 1, 4 p.

Imlay, R. W., Gardner, L. S., Rogers, C. P., Jr., and Hadley, H. D., 1948, Marine Jurassic formations of Montana: U.S. Geol. Survey Oil and Gas Inv. Prelim. Chart 32.

Kummel, Bernhard, 1954, Triassic stratigraphy of southeastern Idaho and adjacent areas: U.S. Geol. Survey Prof. Paper 254-H, p. 165-194.

Love, J. D., 1956, Cretaceous and Tertiary stratigraphy of the Jackson Hole area, northwestern Wyoming, in Wyoming Geol. Assoc. Guidebook 11th Ann. Field Conf., Jackson Hole, 1956 : p. 75-94.

1961, Reconnaissance study of Quaternary faults in and south of Yellowstone National Park, Wyoming: Geol. Soc. America Bull., v. 72, no. 12, p. 1749-1764.

Love, J. D., Hose, R. K., Weitz, J. L., Duncan, D. O., and Bergquist, H. R., 1951, Stratigraphic sections of Cretaceous rocks in northeastern Teton County, Wyoming: U.S. Geol. Survey Oil and Gas Inv. Chart OC-43.

Maughan, E. K., and Roberts, A. E., 1967, Big Snowy and Amsden Groups and the Mississippian-Pennsylvanian boundary in Montana: U.S. Geol. Survey Prof. Paper 554-B, p. B1-B27.

McKee, E. D., Oriel, S. S., Swanson, V. W., MacLachlan, M. E., MacLachlan, J. O., Ketner, K. B., Goldsmith, J. W., Bell, R. Y., and Jameson, D. J., 1956,

Paleotectonic maps of the Jurassic system: U.S. Geol. Survey Misc. Geol. Inv. Map. I-175, 6 p.

McKee, E. D., Oriel, S. S., Ketner, K. B., MacLachlan, M. E., Goldsmith, J. W., MacLachlan, J. C., and Mudge, M. R., 1959, Paleotectonic maps of the Triassic system: U.S. Geol. Survey Misc. Geol. Inv. Map I-300, 33 p.

McKelvey, V. E., and others, 1959, The Phosphoria, Park City, and Shedhorn Formations in the western phosphate field: U.S. Geol. Survey Prof. Paper 313-A, p. 1-47. 
McMannis, W. J., 1962, Devonian stratigraphy between Three Forks, Montana and Yellowstone Park, in Billings Geol. Soc. Guidebook 13th Ann. Field Conf., Three Forks-Belt Mountains area, and Symposium, The Devonian system of Montana and adjacent areas, 1962: p. 4-12.

Montagne, John de la, 1964, Pre-Wisconsin glaciation and its geomorphic significance in Yellowstone Valley, Park County, Montana [abs.]: Geol. Soc. America Spec. Paper 76, p. 284-285.

Myers, W. B., and Hamilton, Warren, 1964, Deformation accompanying the Hebgen Lake earthquake of August 17, 1959 : U.S. Geol. Survey Prof. Paper 435-I, p. 55-98.

Newell, N. D., and Kummel, Bernhard, Jr., 1942, Lower Ero-Triassic stratigraphy, western Wyoming and southeast Idaho: Geol. Soc. America Bull., v. 53, no. 6, p. 987-995.

Parsons, W. H., 1960, Origin of Tertiary volcanic breccias, Wyoming: Internat. Geol. Cong., 21st, Copenhagen, 1960, Rept., pt. 13, p. 139-146.

Peale, A. C., 1896, Three Forks, Montana : U.S. Geol. Survey Geol. Atlas, Folio 24, 5 p.

Peterson, J. A., Gosman, R. F., and Swanson, R. W., 1954, Stratigraphic sections of the Phosphoria Formation in Montana, 1951: U.S. Geol. Survey Circ. $326,27 \mathrm{p}$.

Richmond, G. M., 1964, Glacial geology of the West Yellowstone Basin and adjacent parts of Yellowstone National Park: U.S. Geol. Survey Prof. Paper 435-T, p. 223-236.

Richter, C. F., 1958, Elementary seismology: San Francisco, W. H. Freeman and Co., $768 \mathrm{p}$.

Roberts, A. E., 1957, Coal-bearing rocks and mines at Cokedale, Park County, Montana, in Billings Geol. Soc. Guidebook 8th Ann. Field Conf., Grazy Mountain Basin, 1957 : p. $39-48$.

1963, The Livingston Group of south-central Montana, in Short papers in geology and hydrology : U.S. Geol. Survey Prof. Paper 475-B, p. B86-B92. 1965, Correlation of Cretaceous and lower Tertiary rocks near Livingston, Montana, with those in other areas of Montana and Wyoming, in Geological Survey research 1965 : U.S. Geol. Survey Prof. Paper 525-B, p. B54-B63.

Ross, C. P., Andrews, D. A., and Witkind, I. J., 1955, Geologic map of Montana: U.S. Geol. Survey.

Ross, C. S., and Smith, R. L., 1961, Ash-flow tuffs : their origin, geologic relations, and identification: U.S. Geol. Survey Prof. Paper 366, 81 p.

Rouse, J. T. 1947, The Absaroka volcanic field, in Wyoming Geol. Assoc. Guidebook 2d Ann. Field Conf., Bighorn Basin, 1947 : p. 165-172.

Rowe, J. P., 1906, Montana coal and lignite deposits: Montana Univ. Bull. 37, Geol. Series 2, $82 \mathrm{p}$.

Sanford, A. R., 1959, Analytical and experimental study of simple geologic structures: Geol. Soc. America Bull., v. 70, no. 1, p. 19-51.

Scott, H. W., 1935, Some Carboniferous stratigraphy in Montana and northwestern Wyoming: Jour. Geology, v. 43, no. 8, pt. 2, p. 1011-1032.

Seager, G. F., 1944, Gold, arsenic, and tungsten deposits of the Jardine-Crevasse Mountain district, Park County, Montana : Montana Bur. Mines and Geology Mem. 23, $111 \mathrm{p}$.

Sears, J. D., Hunt, C. B., and Hendricks, T. A., 1941, Transgressive and regressive Cretaceous deposits in southern San Juan basin, New Mexico: U.S. Geol. Survey Prof. Paper 193-F, p. 101-121.

Smith, R. L., 1960, Zones and zonal variations in welded ash flows: U.S. Geol. Survey Prof. Paper 354-F, p. 149-159. 
Tourtelot, H. A., Schultz, L. G., and Gill, J. R., 1960, Stratigraphic variations in mineralogy and chemical composition of the Pierre Shale in South Dakota and adjacent parts of North Dakota, Nebraska, Wyoming, and Montana, in Short papers in the geological sciences: U.S. Geol. Survey Prof. Paper 400-B, p. B447-B452.

Waldron, H. H., and Gard, L. M., Jr., 1951, Preliminary report on the geology of part of the lower Snake River Canyon, Washington: U.S. Geol. Survey open-file report, $66 \mathrm{p}$.

Waldrop, H. A., and Hyden, H. J., 1963, Landslides near Gardiner, Montana, in Short papers in geology, hydrology, and topography : U.S. Geol. Survey Prof. Paper 450-E, p. E11-E14.

Washington, H. S., 1917, Chemical analyses of igneous rocks published from 1884 to 1913, inclusive, with a critical discussion of the character and use of analyses (a revision and expansion of Prof. Paper 14) : U.S. Geol. Survey Prof. Paper 99, $1201 \mathrm{p}$.

Weed, W. H., 1891, The Cinnabar and Bozeman coal fields of Montana: Geol. Soc. America Bull., v. 2, p. 349-364.

1893, The glaciation of the Yellowstone Valley north of the Park: U.S. Geol. Survey Bull. 104, 41 p.

Wilson, C. W., Jr., 1934a, Geology of the thrust fault near Gardiner, Montana: Jour. Geology, v. 42, no. 6, p. 649-663.

1934b, Section of Paleozoic and Mesozoic rocks measured at Cinnabar Mountain, Park County, Montana, and at Mount Everts, Yellowstone National Park, Wyoming: Am. Assoc. Petroleum Geologists Bull., v. 18, no. 3, p. 368-379.

Witkind, I. J., 1964a, Reactivated faults north of Hebgen Lake: U.S. Geol. Survey Prof. Paper 435-G, p. 37-50.

1964b, Structural damage in the Hebgen Lake-West Yellowstone area: U.S. Geol. Survey Prof. Paper 435-B, p. 5-11.

Witkind, I. J., Hadley, J. B., and Nelson, W. H., 1964, Pre-Tertiary stratigraphy and structure of the Hebgen Lake area: U.S. Geol. Survey Prof. Paper 435-R, p. 199-207. 


\section{INDEX}

[Italic page numbers indicate major references]

A

Absaroka Range, defined

Acknowledgments

Aldridge coal district.

Alluvium

Amphibolite

Amsden Formation

Andalusite.

Andesitic breccia

sources

Andesitic material

Arsenic

Arsenopyrite.

Ash Mountain, source for trachyandesite lavas.

\section{B}

Bacon Ridge Sandstone

Basalt. perched remnant use.

Bear Creek, placer gold

Beartooth block

Beartooth uplift. reactivated.

Bentonite. . . . . . Landslide Creek Formation.

Bowers coal mine

Breccia, andesitic.................... 44,46

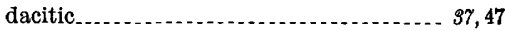
early acid. early basic

Bull Lake glacial deposits

\section{C}

Casey Lake area, trachyandesite flows

Cenozoic rocks.

Chert. . . . . . . . . black.

Chlorite.

Chugwater Formation

Cinnabar Mountain, dead oil intrusions at base. named.

Paleozoic section phosphate rock. section.

Claggett Shale.

Cloverly Formation minature thrust faults at top.

\begin{tabular}{|c|c|}
\hline age & $\mathrm{Coa}$ \\
\hline 6 & Eagle Sandstone.... \\
\hline 3 & economic potential_. \\
\hline 79 & Electric coal field.. \\
\hline 61 & Everts Formation ........ \\
\hline 10 & Gardiner area............ \\
\hline 16 & Landslide Creek Formation. ................ \\
\hline 8 & rail Creek area \\
\hline 49 & location of probable pockets......... \\
\hline 44 & - n \\
\hline 46 & Coal member, Eagle Sandstone \\
\hline 4,35 & Cody Shale \\
\hline 3,82 & trails disrupted by modern deformation . . \\
\hline 9 & Cokedale Formation, Livingston Group....... \\
\hline 43 & Colluvium \\
\hline & Colorado Shale. \\
\hline & $\begin{array}{l}\text { Conglomerate, beneath basalt } \\
\text { chert-pebble, Cloverly Formation }\end{array}$ \\
\hline 30 & Ellis Group \\
\hline 49 & Park City Formation... \\
\hline 67 & younger than basalt. . \\
\hline 83 & Construction, future, safety ..... \\
\hline 82 & Cordierite \\
\hline 48 & Crevice Mou \\
\hline 6,62 & Cummingtonite... \\
\hline
\end{tabular}

Page

\section{D}

Dacite sill south of the Gardiner fault ........ $\quad 48$

Dacitic breccia............................ 37 relation to dacitic intrusives.............. 47

Dacitic intrusives north of the Gardiner fault. $\quad 47$

Deckard Flats, basalt ....................... 51 basalt bench........................... 68 gold-bearing conglomerate............... 56

Devils Slide................................... 20

Dinwoody Formation . . . . .

\section{$\mathbf{E}$}

Eagle Creek area, ice-marginal channels...... 58

Eagle Nest Rock, gravel-filled abandoned channel.......................... 61

Eagle Sandstone............................ 27 coal . . .

Electric coal field..................... 78 depositional environment.................. 30,84 description............................ 28 fossils

measured coal section.................. 81

Earthquakes.................. 74 
Economic geology

Page

Electric coal field

Electric Peak volcano

Ellis Group

Eocene topography, exhumed

Erosion, periods.

Everts fault

Everts Formation.

depositional environment

\section{F}

Faulting, age..............

Hebgen Lake area

miniature thrusts, geometry

problems created in coal mining

Quaternary

regional relations

superficial, associated with landslides

transverse

young, age

See also Everts fault; moth fault; Reese Creek fault.

Fieldwork

Folding place in structural history relation to faulting.

Folds, major syncline.

Fort Hays Limestone Member, Niobrara Formation

Fossils, Amsden Formation andesitic breccia.

Anomia sp.

Brachidontes sp.

Cloverly Formation

Corbula sp

Crassatella andrewsi.

Crassostrea soleniscus.

Cymbophora arenaria utaensis.

dacitic breccia

dinosaur bones

Dinwoody Formation

Eagle Sandstone.

Gish scales

gastropods....................................

Haplophragmoides calcula.

Inoceramus involutus

platinus.

stantoni.

sp.

leaves

Mowry Shale.

ostracodes

Ostrea coalvillensis

sp.

Park City Formation

pelecypods.

plant debris

pollen

Quadrant Quartzite

Scaphites binneyi

17
Fossils-Continued

Page

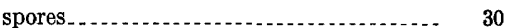

Telegraph Creek Formation........... 28

Thermopolis Shale.................... 24

trachyandesite flows..................... 41

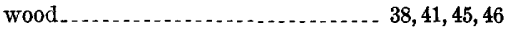

worm trails........................... 24

Frontier Formation.................... 25

\section{G}

Gabbro, intrusion........................ 14

Gardiner, Mont., guide to safety in future development.................... 75

Gardiner fault, deformation of drag zone by transverse faults................ 76

$\operatorname{dip} \ldots 3$

displacement.......................... 63

geologic history

junction with Mammoth fault . . . . . . . . 76

key horizon in fault zone............... 25

Laramide structure in drag zone ... . . . . . 64

Mesozoic section removed............... 19

new interpretation.

Paleozoic section removed. . . . . . . . . . . 15

Quaternary reactivation................ 67

relation to Cenozoic intrusives........... $\quad 47$

relation to travertine deposits............. $\quad 57$

surficial modification of drag-zone structure............................. 66

Gardner River, fault control.............. 7

Garnet...................................... 8

Gas.................... 83

Geologic history of area, Phanerozoic........ 84

Precambrian............................ 12

Glacial deposits, description............... 57

Pinedale

undifferentiated....................... 58

Glauconite ............. 20,21,26

Gneiss, amphibole........................... 10

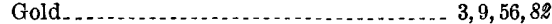

Granite ................. 10

intrusion............................... 14

use........................................ 83

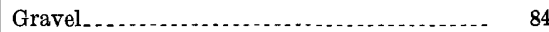

Gypsum . . . . . . .

Gypsum Spring Formation.......... 21

$\mathrm{H}$

Harebell Formation. ..................... 36

Hebgen Lake area, faulting .................. 74

Heulandite.................................. 35

Hot springs, localization.......

I

Intrusive rocks........................... 47

J

Jardine district, arsenopyrite-gold-scheelite mineralization.................. 9,82

Jones coal mine................................

Judith River Formation ................ 37

K

27 Kootenai Formation 
Laboradorite.

$\mathrm{N}, \mathrm{O}$

Landslide Creek, section.

Landslide Creek Formation, baked remnants. coal.

depositional environment

description popcorn weathering

Landslides.

Quaternary

Lapilli tuff.

Lava flows basal, irregularities.

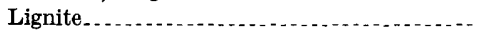

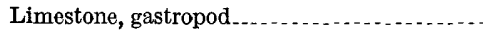

Lineation

Little Trail Creek, perched basalt.......... section. . . . . . . . . . . . . . . . . . . .

Little Trail Creek area, coal. ... .............

Livingston area, coal mining.

Livingston Group.

Location of area

Lost Creek Trachyte.

Lost Creek Tuff.

M

Madison L

Mammoth, Wyo., hot springs..............

Mammoth fault.

Marker bed, in Cloverly Formation

in Frontier Formation

in Quadrant Quartzite

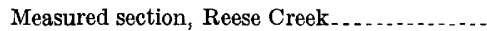
Cinnabar Mountain. ...................

Landslide Creek..

Little Trail Creek. ........................

Mount Everts 1..........................

Mount Everts 2..........................

Mount Everts 3............................

Mount Everts 4.

Measured sections, location and thickness data ...........................

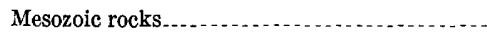

Metagabbro

Metamorphism.

Metasedimentary rocks.

Mineral Hill.

Mineralization, hydrothermal, Jardine district 14,82

Morrison Formation

Mount Everts .............................. 32

andesite sill near base..................... 49

glacial deposits . . . . .

glacial features....................... 59

section 1 ....................................

section 2 .

section $3 \ldots \ldots \ldots$

section 4............................... 104

Mowry Shale................................ 24

Muddy Sandstone Member, Thermopolis Shale.

Niggerhead Peak, glacial erratics

Page

Oil

58

83

Paleozoic rocks................... 16

Park City Formation

Parkman Sandstone......................... 33

Phelps Creek area, ice-marginal channels ..... $\quad 58$

Phosphate rock.............................. 84

Phosphoria Formation.................... 18

Phyllite......................................... 10

Physiographic setting of area............ 6

Pinedale glacial deposits.................... 58, 59

Piper Formation.

Plagioclase

Porcellanite beds....................... 25, 26, 38

Precambrian rocks, discussion ............... 7

fragments in dacitic intrusives.......... $\quad 47$

in dacitic breccia. . . . . . . 38

inclusions in Yellowstone Tuff . . . . . . ... $\quad 55$

mining ............................. 82

Previous studies...... 5

Quadrant Quartzite

miniature thrust faults at top......... 65

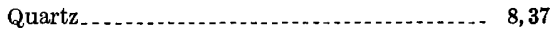

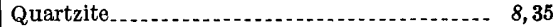

Quaternary deformation..................... 67

Quaternary structures, minor............... 69

\section{$\mathbf{R}$}

Red beds, Chugwater Formation......... 20

Reese Creek, section....................... 110

Reese Creek fault........... 77

Reese Formation. . . .

References cited......................... 110

Retort Phosphatic Shale Tongue, Phosphoria Formation................... 18

Rierdon Formation

\section{S}

Safety in future development in area........ $7_{5}$

Sand .............................................. 84

Sandstone-porcellanite association............ 25

Sawtooth Formation .................... 20

Schist, quartz-amphibole_.............. 9 quartz-biotite

Schistosity, regional ........................... 13

Sepulcher Mountain, andesitic breccia cap.... $\quad 46$ dacite sill at base.......................... 48 glacial deposits. . . . landslides.............. 60

Shedhorn Sandstone......................... 18

Shoshonite................................. 42

Sill, dacite, south of Gardiner fault. ......... 48

Sillimanite. . . . . . . . . . .

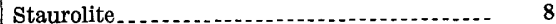

Structural history of area, Laramide......... 62

Precambrian.......................... 12

45 Quaternary $\ldots 7$ 


\section{INDEX}

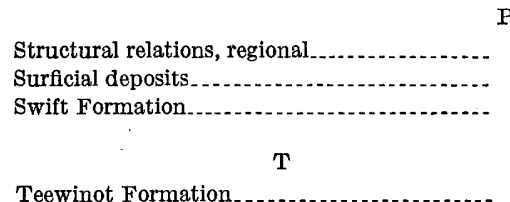

Teewinot Formation.

Telegraph Creek Formation

Terraces.

Tertiary rocks, inclusions in Yellowstone Tuff-.

Thermopolis Shale Tosi Chert Member, Phosphoria Formation.Tourmaline, black

Trachyandesite flows.

Trachybasalt

Trachyrhyolite welded tuff
Page

68

56

20

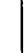

56

26,27

61

55

23

7

39

18

9

41

42

\begin{tabular}{r|l}
42 & Yellowstone Tuff............................................
\end{tabular}

Page

57,83

age of deposition.......................... 69

Tridymite........................... 55

Tungsten $\ldots \ldots \ldots \ldots$

$$
\mathrm{U}, \mathrm{V}, \mathrm{Y}
$$

Unconformity, major, end of Cretaceous..... $\quad 34$

Virgelle Sandstone Member, Eagel Sandstone. $\quad 29$

Vitrophyre............................... 54

Volcanic rocks, upper Cenozoic............ $\quad 49$

Volcanism, Eocene.......................... 86

7 